
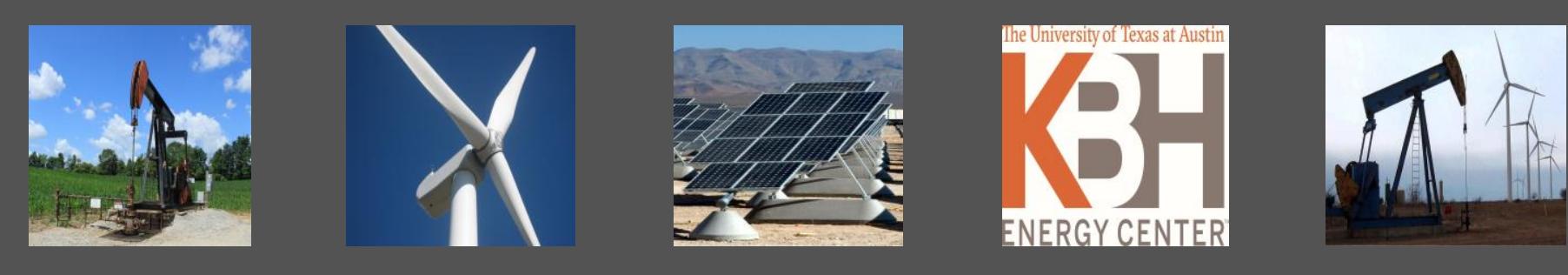

Protecting Species or Endangering Development? How Consultation Under the Endangered Species Act Affects Energy Projects on Public Lands

Melinda Taylor, Romany Webb, and Vanessa Puig-Williams

August 2016

The University of Texas at Austin

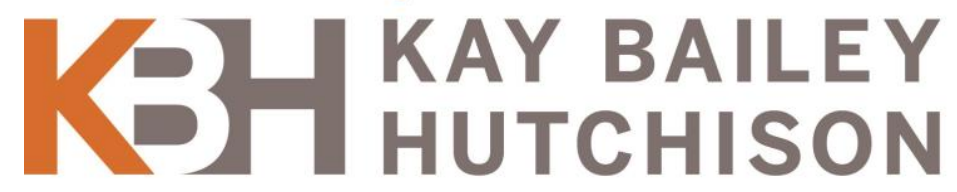

CENTER FOR ENERGY, LAW \& BUSINESS ${ }^{\text {"w }}$ 


\section{Protecting Species or Endangering Development? How Consultation Under the Endangered Species Act Affects Energy Projects on Public Lands}

Research Paper No. 2016-03

August 2016

AUTHORS

Melinda Taylor, Romany Webb, and Vanessa Puig-Williams

PRESENTED BY

Kay Bailey Hutchison Center for Energy, Law, and Business

University of Texas School of Law and McCombs School of Business

727 East Dean Keeton Street

Campus Mail Code: D1800

Austin, TX 78705

(512) $232-1408$

The University of Texas at Austin

\section{GAY BAILEY D) HUTCHISON}

CENTER FOR ENERGY, LAW \& BUSINESS

http://kbhenergycenter.utexas.edu/

C) 2016 All rights reserved 


\section{ABOUT THE KBH ENERGY CENTER}

The Kay Bailey Hutchison Center for Energy, Law, and Business is an innovative interdisciplinary academic center created by the School of Law and the McCombs School of Business at The University of Texas at Austin. The mission of the KBH Energy Center is to provide the finest educational opportunities in the United States to students who wish to pursue careers in energy and to serve as a nexus for incisive, unbiased, and relevant research and conferences for policymakers, with a special focus on Latin America.

\section{ABOUT THE AUTHORS}

Melinda Taylor is a Senior Lecturer in the School of Law and the Executive Director of the $\mathrm{KBH}$ Energy Center. Prior to joining the faculty, Taylor was the Director of the Ecosystem Restoration Program at the Environmental Defense Fund, where she worked to protect endangered species and water resources. She has also served as Deputy General Counsel of the National Audubon Society and was as an associate at Bracewell \& Patterson in Washington D.C.

Romany Webb is a Post-Graduate Research Fellow in the KBH Energy Center. Her current research focuses on managing the environmental impacts of energy production. She previously worked at the University of California, Berkeley, where she researched climate change policy, and has practiced energy and water law in Sydney, Australia.

Vanessa Puig-Williams is an Affiliated Fellow in the KBH Energy Center. Vanessa is an Austinbased legal consultant with expertise in Texas environmental law. She currently practices conservation law and writes on endangered species issues. She previously practiced in the environmental division of the Texas Attorney-General's Office.

\section{ACKNOWLEDGEMENTS}

The authors would like to thank Janani Srinivasan, a former research assistant at the KBH Energy Center, for her help researching this paper. The authors are also grateful to Mauricio Pajón of the KBH Energy Center for his assistance with the production of this document. Any errors are our own.

i | Protecting Species or Endangering Development | August 2016 


\section{Table of Contents}

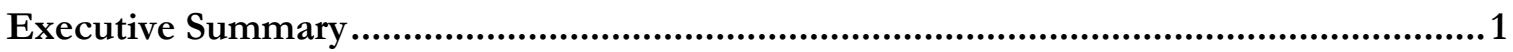

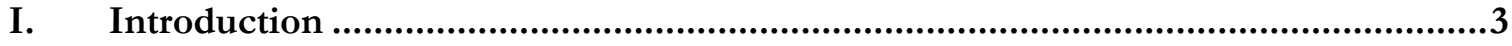

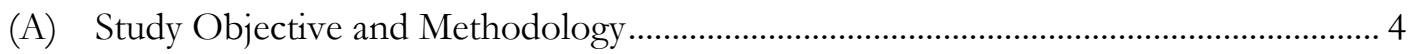

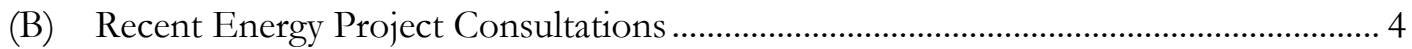

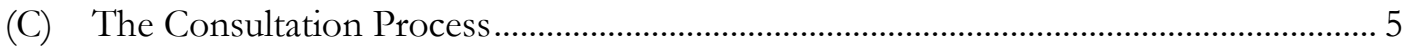

(D) Improving the Consultation Process ....................................................................... 5

II. Background: The Endangered Species Act ....................................................6

(A) The Section 7 Consultation Process …...................................................................... 7

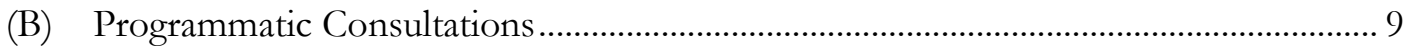

(C) Coordination with Other Environmental Reviews................................................... 10

III. Federal Land Management and the Endangered Species Act ............................ 11

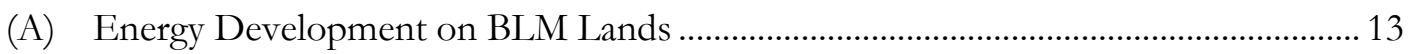

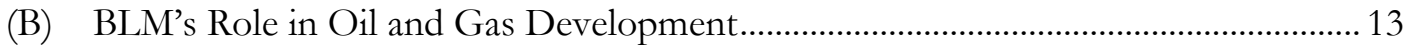

(C) BLM's Role in Renewable Energy Development ..................................................... 16

IV. Managing the Impacts of Energy Development on BLM Land ............................ 19

(A) Potential Impacts of Oil and Gas Development ............................................................ 20

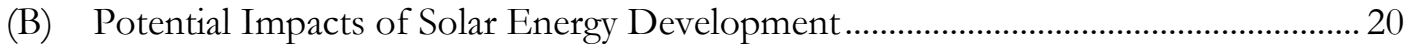

(C) Potential Impacts of Wind Energy Development ........................................................ 22

V. Energy Projects Reviewed Under the Endangered Species Act.............................23

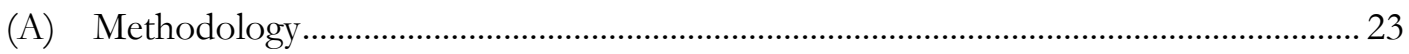

(B) Consultations Relating to Energy Projects on BLM Lands ......................................... 28

(C) Oil and Gas Projects Subject to Consultation.............................................................. 30

(D) Consultations Relating to Renewable Energy Projects ................................................... 31

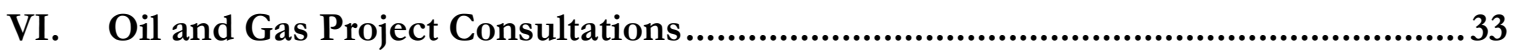

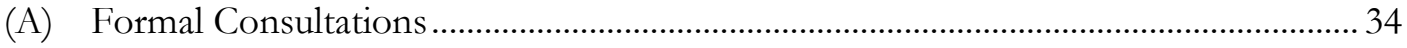

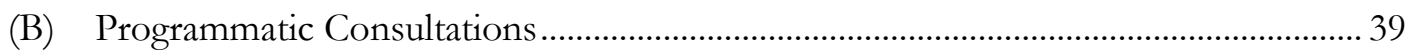

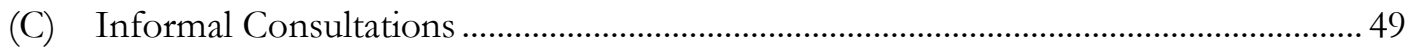

VII. Solar Energy Project Consultations …...............................................................50

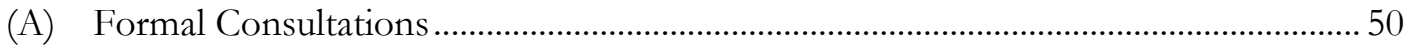

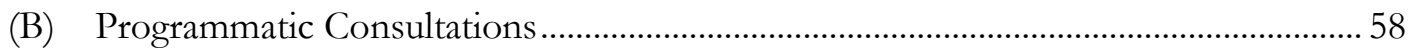

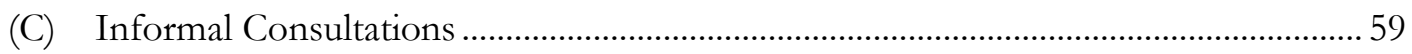

ii | Protecting Species or Endangering Development | August 2016 


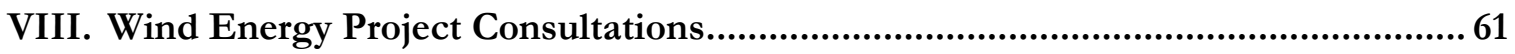

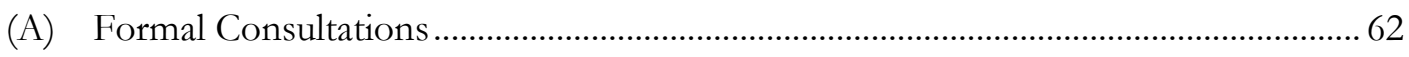

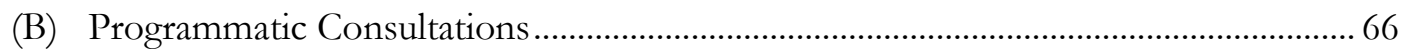

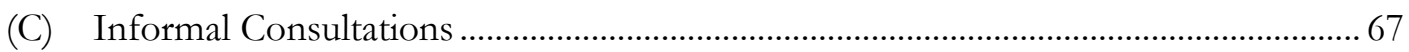

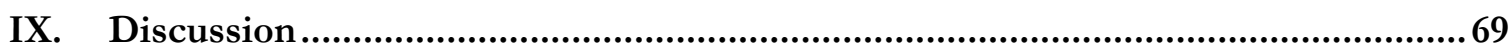

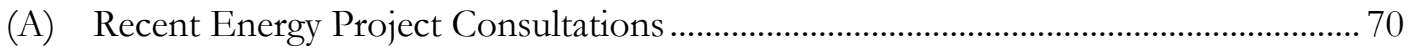

(B) Industry Complaints About the Consultation Process ................................................... 71

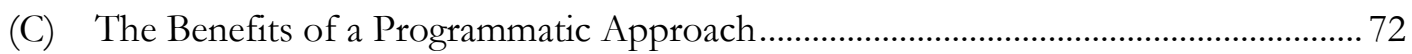

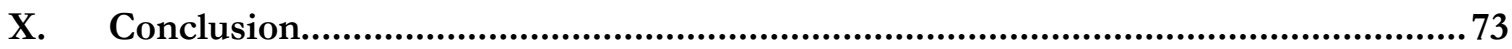

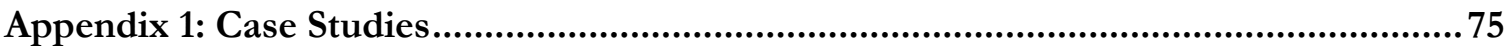




\section{Acronyms}

APD Application for permit to drill

BA Biological Assessment

BLM Bureau of Land Management

BMP Best management practice

BO Biological Opinion

CSP Concentrating solar power

DOI Department of the Interior

DRECP Desert Renewable Energy Conservation Plan

EA Environmental Assessment

EIS Environmental Impact Statement

ESA Endangered Species Act

FLPMA Federal Land Policy and Management Act

FWS Fish and Wildlife Service

LUPA Land Use Plan Amendment

MW Megawatt

NEPA National Environmental Policy Act

NMFS National Marine Fisheries Service

PBO Programmatic Biological Opinion

PRRIP Platte River Recovery Implementation Program

PV Photovoltaic

RIP Recovery Implementation Program for Endangered Fish Species in the Upper Colorado River Basin

RMP Resource Management Plan (also known as a Land Use Plan)

ROW Right of way

RPA Reasonable and prudent alternative

SEZ Solar energy zone

TAILS Tracking and Integrated Logging System

WEDP Wind Energy Development Plan

WUMDP Whitewater Unit Master Development Plan

WPMDP Western Properties Master Development Plan

iv | Protecting Species or Endangering Development | August 2016 


\section{Executive Summary}

Throughout its forty-three-year history, the Endangered Species Act ("ESA") has been one of the most celebrated environmental laws but also one of the most reviled. After passing with strong bi-partisan support in 1973, the ESA has recently faced growing opposition, amid concerns that it has failed to adequately protect species, while unreasonably impeding economic development. Much of the criticism has been directed towards section 7 of the ESA, which requires federal agencies to ensure that actions they undertake or authorize do not jeopardize threatened or endangered species, by consulting with the U.S. Fish and Wildlife Service ("FWS"). Industry groups have argued that the consultation requirement frequently stops or delays much needed energy, transportation, water supply, and other projects.

This study seeks to assess the impact of consultation, under section 7 of the ESA, on energy development on public land. To this end, the study analyzes 179 consultations undertaken between FY2010 and FY2014 with respect to oil, gas, solar, and wind energy projects on public land managed by the Department of Interior's Bureau of Land Management ("BLM"). Basic information about each consultation, including a brief description of the project involved and a list of species affected, was obtained from FWS's Tracking and Integrated Logging System. We also reviewed the biological opinions and concurrence letters issued by FWS and, for a subset of consultations, interviewed agency staff and industry representatives involved.

\section{CONSULTATIONS ANALYZED}

- Total consultations -179

○ Formal consultations - 54

- Informal consultations -125

- Oil and gas project consultations - 143

- Formal consultations - 29

○ Informal consultations - 114

- Solar energy project consultations - 27

- Formal consultations - 19

- Informal consultations -8

- Wind energy project consultations - 9

- Formal consultations - 6

○ Informal consultations - 3

Key findings from the analysis include:

- A relatively small number of energy projects authorized on federal lands between FY2010 and FY2014 went through the consultation process. The majority (eighty percent) of consultations that were carried out involved oil and gas drilling projects. Fifteen percent of consultations related to solar energy projects and five percent to wind energy projects.

- Only a small proportion (ten percent) of all oil and gas drilling projects approved by BLM from FY2010 to FY2014 were subject to consultation. In contrast, eighty-two percent of

1 | Protecting Species or Endangering Development | August 2016 
BLM approved solar energy projects and seventy-one percent of BLM approved wind energy projects underwent consultation.

- Most of the energy project consultations undertaken between FY2010 and FY2014 were completed within the 135 day time limit set in the ESA. There was, however, often significant back-and-forth between FWS, BLM, and the project proponent prior to the official start of consultation. This is a concern for industry, as pre-consultation discussions can add significant time to the review process and thereby lead to project delays.

- The need to consult can also give rise to significant uncertainty for industry. The assessment of project effects and the measures required to mitigate those effects often differs markedly between, and even within, FWS offices. Similar projects may, therefore, be assessed differently depending on the FWS staff handling the consultation.

- FWS has recently taken steps to address industry concerns regarding the potential for project delays and inconsistencies in the review process. To this end, FWS has issued a number of programmatic biological opinions, which cover multiple similar actions.

- Where a project is covered by a programmatic biological opinion, consultation tends to proceed more quickly, and there is less need for pre-consultation discussions. The existence of a programmatic biological opinion can also greatly reduce the complexity of consultation and generally leads to increased certainty for project developers. 


\section{Introduction}

Recognizing that, "as a consequence of economic growth and development," numerous "species of fish, wildlife, and plants...have been rendered extinct" and others "are in danger of or threatened with extinction," Congress passed the Endangered Species Act ${ }^{1}$ ("ESA" or "Act") in 1973..$^{2}$ The Act establishes a comprehensive program for the conservation of imperiled species and the habitats upon which they depend. ${ }^{3}$ Under the Act, protection is afforded to species listed as endangered or threatened by the U.S. Fish and Wildlife Service ("FWS") or National Marine Fisheries Service ("NMFS"). The number of listed species has increased over time, from less than 400 in $1973,{ }^{4}$ to over 2,200 in $2016 .{ }^{5}$

At the time of its enactment in 1973, the ESA received strong bi-partisan support, passing the House of Representatives by a 379 vote margin $^{6}$ and the Senate unanimously. ${ }^{7}$ Over time, however, the ESA has become increasingly contentious with many industry bodies arguing that it unreasonably impedes economic development. ${ }^{8}$ In response to industry complaints, some federal lawmakers have recently sought to amend the ESA, to weaken its protections. During the five years from 2011 to 2015, lawmakers introduced 164 bills and riders aimed at reducing the protections in the ESA, including by preventing listing or forcing delisting of species, and/or otherwise limiting implementation of the Act. ${ }^{9}$

Much of the criticism from lawmakers, industry groups, and others has focused on section 7 of the ESA. That section requires each federal agency to "insure that any action authorized, funded, or carried out by [it]... is not likely to jeopardize the continued existence of any endangered or threatened species or result in the destruction or adverse modification of habitat of such species." 10 To that end, federal agencies must consult with FWS 11 or NMFS 12 on any proposed action that may affect listed species. The consultation process has been heavily criticized by industry, which argues that it often results in projects being stopped or significantly delayed, and can dramatically increase project costs. ${ }^{13}$ These claims have, however, been disputed.

A 2015 study analyzing 88,290 consultations undertaken between January 2008 and April 2015 found that, "[i]n contrast to conventional wisdom about section 7 implementation, no project was stopped or extensively altered as a result of FWS finding jeopardy or adverse modification" during consultation. ${ }^{14}$ The median duration of consultation was found to be far lower than the maximum allowed by the ESA. ${ }^{15}$ Notably however, in calculating consultation duration, the study's authors did not include the time spent discussing a project before consultation is officially initiated. Nor did the authors analyze the extent to which these discussions resulted in project alterations. ${ }^{16}$

3 | Protecting Species or Endangering Development | August 2016 


\section{(A) Study Objective and Methodology}

Building on this prior research, our work aims to provide a more complete picture of the effect of section 7 consultation on energy development projects. We focused on projects involving oil, gas, solar, and wind energy development (together "energy projects") on public lands. These projects were chosen as energy developers have been among the fiercest critics of the ESA. The Western Energy Alliance, for example, has argued that:

Misuse of the ESA can prevent energy development... Far too often the ESA has been used as a means to prevent or delay responsible economic activity rather than for species protection. When applied too broadly ... the ESA can have very negative economic and job impacts on western states, local communities, and the nation. ${ }^{17}$

This study analyzes consultations, undertaken pursuant to section 7 of the ESA between FY2010 and FY2014, involving energy projects on public land managed by the Bureau of Land Management ("BLM"). As the majority of BLM-managed land is located in the western half of the country, the analysis focuses on energy project consultations in the seventeen westernmost states in the continental U.S., as well as Hawaii. We did not analyze any consultations undertaken in other states.

Basic information about each consultation, including a brief description of the project involved and a list of species affected thereby, was obtained from FWS's Tracking and Integrated Logging System ("TAILS"). To supplement this information, we also reviewed the biological opinions ("BOs") and concurrence letters issued in each consultation. We then selected a small number of consultations for further study. We interviewed agency staff and, where possible, industry representatives involved in the selected consultations to gain a better understanding of how they played out in practice.

\section{(B) Recent Energy Project Consultations}

Our research identified 179 consultations, relating to energy projects on BLM lands, undertaken between FY2010 and FY2014. The vast majority (eighty percent) of those consultations involved oil and gas development. The number of consultations relating to oil and gas developments is, however, fairly small when assessed relative to all oil and gas developments authorized by BLM from FY2010 to FY2014. We estimate that just ten percent of all authorized oil and gas
SECTION 7 CONSULTATIONS ON ENERGY PROJECTS (FY2010 - FY2014)
- Total consultations - 179
○ Oil and gas projects -143
- Solar energy projects -27
○ Wind energy projects - 9 
developments were subject to consultation.

A larger proportion of BLM authorized renewable energy projects were subject to consultation. Between FY2010 and FY2014, thirty-six consultations were undertaken with respect to renewable energy projects, of which twenty-seven (seventy-five percent) involved solar energy development, and nine (twenty-five) percent related to wind development. We estimate that approximately eighty-two percent of all solar energy developments and seventy-one percent of all wind energy developments authorized by BLM between FY2010 and FY2014 were subject to consultation.

\section{(C) The Consultation Process}

Our analysis suggests that most recent consultations involving energy projects on BLM lands were completed fairly quickly. This is particularly true of consultations relating to oil and gas projects, which took an average of thirty-three days, well below the 135 day time limit set in the ESA. Consultations on renewable energy projects generally took longer, with solar energy project consultations lasting 131 days on average, and wind energy project consultations lasting 144 days on average.

The figures above do not include the often significant time spent discussing a project prior to consultation. Our analysis indicates that the consultation process is generally highly collaborative, involving significant back-and-forth between FWS, BLM, and the project proponent, much of which occurs prior to the official start of consultation. During these pre-consultation discussions, considerable time and effort may be devoted to developing conservation measures, to minimize any adverse impacts of the project on listed species. Several industry representatives we interviewed expressed frustration with this process, noting that pre-consultation discussions can add significant time to the review process, resulting in project delays.

The industry representatives we interviewed also raised concern about inconsistencies in the treatment of projects. Industry complained that the assessment of project effects and the measures required to minimize those effects often varies, between and even within FWS offices. As a consequence, similar projects may be treated differently depending on the FWS staff assigned to the consultation. This results in considerable uncertainty for developers, a problem acknowledged by several of the agency staff we interviewed.

\section{(D) Improving the Consultation Process}

Responding to industry concerns, FWS has recently taken steps to streamline the consultation process and, to this end, has issued a number of programmatic BOs ("PBOs"), covering multiple similar actions. In the PBO, FWS analyzes the likely effects of certain types of actions, and may

5 | Protecting Species or Endangering Development | August 2016 
identify conservation measures, designed to minimize those effects. When a specific action is proposed, FWS may conduct a second review, but that review can proceed on an expedited basis, with FWS relying on the analysis in the PBO. Approximately twelve percent of energy project consultations, undertaken between FY2010 and FY2014, involved such expedited review.

The existence of a PBO can dramatically reduce the time spent consulting on energy projects. As an example, formal consultations on oil and gas projects covered by a PBO were, on average, ninety percent shorter than standard formal consultations. These time-savings were identified by industry representatives as a key benefit of proceeding under a PBO. Industry representatives and agency staff also noted that existence of a PBO can greatly simplify the consultation process and typically results in greater consistency between project reviews. For example, PBOs often include "boiler-plate" conservation measures designed to minimize the impacts of future projects and thereby provide project developers with greater certainty regarding the steps they may be required to take.

\section{Background: The Endangered Species Act}

The ESA establishes "a program for the conservation of . . . endangered species and threatened species." 18 For the purposes of the ESA, an "endangered species" is one which is in danger of extinction throughout all or a significant portion of its range and a "threatened species" is one which is likely to become endangered in the foreseeable future. ${ }^{19}$ Under section 4 of the ESA, FWS must determine whether a species is endangered or threatened due to habitat destruction or modification, over-utilization for commercial or other purposes, disease or predation, inadequate regulation, or other natural or manmade factors. ${ }^{20}$

The listing of a species as endangered or threatened entitles it to protection under the ESA. ${ }^{21}$ The two primary mechanisms through which the ESA protects listed species are set out in sections 7 and 9. Under section 7 of the ESA, federal agencies must ensure that their actions are "not likely to jeopardize the continued existence of any [listed] species or result in the destruction or adverse modification of [any critical] habitat" of those species. ${ }^{22}$ Section 9 is somewhat broader, prohibiting both federal and private actors from taking endangered species, with "take" defined broadly to include "harass, harm, pursue, hunt, shoot, wound, kill, trap, capture, or collect." 23

6 | Protecting Species or Endangering Development | August 2016 


\section{(A) The Section 7 Consultation Process}

Section 7 of the ESA establishes a process by which a federal agency, commonly referred to as the action agency, may consult with FWS about proposed actions. Consultation is designed to assist the action agency to fulfill its duty, under section 7(a)(2), to ensure its actions do not jeopardize listed species or destroy or adversely modify critical habitat. Consultation is required whenever an action proposed to be conducted, funded, or authorized by the agency may affect listed species. The agency's determination as to the effects of an action, and the need for consultation, is set out in a biological assessment ("BA"). ${ }^{24}$

Subject to limited exceptions, the action agency must complete its BA within 180 days, and then submit it to FWS. ${ }^{25}$ Based on the findings of the BA, the action agency may request that FWS initiate consultation on an informal or formal basis. Informal consultation occurs where the agency determines that an action "may affect, but is not likely to adversely affect" listed species. If the action may have adverse effects, formal consultation must be undertaken.

Where the action agency requests informal consultation, FWS must respond within thirty days, indicating whether it concurs that adverse effects are unlikely. ${ }^{26}$ If FWS responds with a concurrence letter, the consultation process is terminated, and the action may move ahead. ${ }^{27}$ In all other situations, however, formal consultation must be undertaken before the action can proceed.

Informal consultation is an optional process, designed to assist the action agency in determining whether a project may adversely affect listed species, such that formal consultation is required. ${ }^{28}$ As a consequence, while informal consultation often precedes formal consultation, this is not required. Where it is clear from the outset that an action may adversely affect listed species, the action agency may request formal consultation without first going through the informal process. ${ }^{29}$

On receiving a request for formal consultation, FWS will conduct a review to assess whether the action is likely to jeopardize the continued existence of listed species or destroy or adversely modify critical habitat. This review may last up to ninety days, after which time FWS must issue a BO, within forty-five days. The BO reflects FWS's view as to whether the project will result in jeopardy to listed species. In undertaking this assessment, FWS begins by looking at the current status of the species, and then adds the various effects (direct, indirect, interrelated, and interdependent) of the action, and the cumulative effects of other non-federal activities. ${ }^{30}$

If FWS determines that an action is likely to jeopardize listed species or adversely modify critical habitat, the action agency may still move forward, but risks being prosecuted for breach of section 7 of the ESA. FWS must notify the agency of any alternative methods of implementing the action ("reasonable and prudent alternatives" or "RPAs") which would avoid it violating the

7 | Protecting Species or Endangering Development | August 2016 
ESA. ${ }^{31}$ RPAs are not identified for other actions that are considered unlikely to jeopardize listed species. The BOs for those actions may, however, specify discretionary conservation measures designed to lessen any adverse impacts on listed species. ${ }^{32}$

Where FWS determines that a federal action, which is unlikely to jeopardize the continued existence of a species, may result in the take thereof, it will prepare an incidental take statement for the action. ${ }^{33}$ Although the ESA generally prohibits the taking of listed species, FWS may permit take which is incidental to, and not the purpose of, an otherwise lawful activity. ${ }^{34}$ The incidental take statement specifies the amount or extent of anticipated take due to the action, identifies reasonable and prudent measures to minimize take, and outlines terms and conditions to be observed in implementing the measures. ${ }^{35}$ The reasonable and prudent measures, and the terms and conditions that implement them, must not "alter the basic design, location, scope, duration or timing of the action and may involve only minor changes." 36

\section{INTERAGENCY CONSULTATION IN PRACTICE}

Within the general parameters set out above, interagency consultations may vary significantly, depending on a range of factors. The consultation process may be impacted by, among other things, the nature of the proposed action, the location in which it is to occur, and the species found therein. For most projects, the process is highly collaborative and often involves significant back-and-forth between FWS, the action agency, and the applicant (if any).

Before officially requesting consultation, the action agency will generally hold discussions with FWS, to obtain its initial views on the action. FWS encourages such pre-consultation discussions, arguing that they result in projects with fewer effects on species and habitat, by providing an opportunity to incorporate mitigation measures at an early stage. Pre-consultation discussions may, however, add significant time to the review process. According to FWS staff, preconsultation discussions can last 18 months or more, depending on the project's complexity.

Discussions between FWS, the action agency, and the applicant (if any) often continue after the initiation of consultation. For complex projects in particular, there may be numerous email exchanges, telephone calls, and in-person meetings between agency staff and any applicant. Through these communications, the parties may exchange information regarding the likely impacts of the project, and agree on measures to minimize those impacts. In formal consultations, FWS may provide the action agency and any applicant with a draft of its BO and invite them to provide comments. ${ }^{37}$

8 | Protecting Species or Endangering Development | August 2016 


\section{(B) Programmatic Consultations}

Consultation has traditionally been undertaken separately for each federal action. Such action-byaction consultation can, however, take significant time and lead to increased costs for FWS and the action agency. ${ }^{38}$ In addition, it can also give rise to other, more serious problems. Some commentators have expressed concern that, where consultation is undertaken separately for each action, FWS may fail to adequately address the cumulative impacts of all actions. ${ }^{39}$ FWS may not be aware of small projects that are determined by the action agency to have "no effect" on listed species and, as a result, may fail to consider those projects when assessing the cumulative effects of other activities. ${ }^{40}$

Responding to these concerns, in recent years, FWS has increasingly utilized a programmatic consultation process. The term "programmatic consultation" may refer to consultations evaluating the effects of:

- federal agency programs establishing general guidelines for particular types of actions;

- multiple actions of the same or similar type; or

- a group of different actions proposed to occur within the same area. ${ }^{41}$

In each case, following consultation, FWS issues a PBO addressing the effects of future actions of a specified type and setting out general conservation measures to apply to those actions. When an action of that type is proposed, additional documentation will generally be prepared. This documentation may take one of two forms:

- Under the "tiered programmatic consultation approach," for actions covered by a PBO, FWS may issue a tiered BO. This is similar to a standard BO in that it analyzes the likely effects of the action and identifies conservation measures to offset those effects. It is, however, generally easier to complete because it incorporates data and analysis from the previous PBO.

- Under the "appended programmatic consultation approach," an action covered by a PBO may be appended thereto, eliminating the need for a separate BO. In such cases, the action agency will notify FWS that it considers a proposed action to be consistent with the PBO. FWS may issue a letter confirming the agency's view and appending the action to the PBO.

FWS generally undertakes programmatic consultations on land use plans and other landscapelevel proposals. ${ }^{42}$ FWS may also combine multiple small projects, to be carried out or authorized by a federal agency, into a single programmatic consultation. ${ }^{43}$ By way of example, on June 16, 2006, FWS issued a PBO on projects involving water depletions from the Platte River basin. ${ }^{44}$ The PBO analyzed the likely impact of water depletions on three species of birds and one

9 | Protecting Species or Endangering Development | August 2016 
species of fish listed under the ESA. This analysis provides the basis for reviewing individual projects of various types that involve water withdrawals from the Platte River basin.

In the course of this study, we reviewed the following five programmatic consultations, which apply to certain energy projects:

- the Oil and Gas PBO dated July 17, 1996, as revised and extended on September 28, 2001, addressing small scale projects associated with BLM's oil and gas leasing in Kings and Kern Counties in California; 45

- the 1999, 2005, and 2009 PBOs issued with respect to the Recovery Implementation Program for Endangered Fish Species in the Upper Colorado River Basin ("RIP”), which applies to projects involving water depletions from the Upper Colorado River Basin; ${ }^{46}$

- the 2006 PBO issued with respect to the Platte River Recovery Implementation Program (“PRRIP”), which covers projects involving water depletions from the Platte River Basin;47

- the 2005 PBO on BLM's Wind Energy Development Program;48 and

- the 2012 PBO on BLM’s Solar Energy Program. ${ }^{49}$

There may be other programmatic consultations relevant to energy development on BLM lands.

\section{(C) Coordination with Other Environmental Reviews}

Section 7 consultation occurs in addition to, and must be coordinated with, reviews mandated by other environmental laws including the National Environmental Policy Act ("NEPA"). This largely procedural law requires federal agencies to consider environmental impacts before taking any action. To facilitate such consideration, NEPA directs agencies to prepare an Environmental Impact Statement ("EIS") for all "major federal actions significantly affecting the quality of the human environment." 50 To determine whether an action has significant effects, agencies typically prepare an Environmental Assessment ("EA"), which briefly describes the action and analyzes its likely impacts. ${ }^{51}$ If that analysis indicates that the action's impacts may be significant, the agency must prepare a more comprehensive EIS. ${ }^{52}$

NEPA reviews typically occur in parallel with ESA consultation. To reduce duplication, the action agency may incorporate the BA required for ESA consultation into any EA or EIS prepared in fulfillment of NEPA. ${ }^{53}$ Alternatively, a separate BA may be completed prior to the release of the draft EA or EIS. ${ }^{44}$ Regardless of which approach is taken, section 7 consultation should be completed by the time any final EIS is issued, so that the results of consultation can be included therein. ${ }^{55} \mathrm{FWS}$ recommends that, to achieve this deadline, formal consultation (if required) should be initiated prior to or at the time of release of the draft EIS. 56

10 | Protecting Species or Endangering Development | August 2016 


\section{Federal Land Management and the Endangered Species Act}

The federal government owns twenty-eight percent of land in the U.S., or approximately 650 million acres, of which more than three-quarters is managed by the Department of the Interior ("DOI"). Within the DOI, BLM is the largest land manager, with responsibility for approximately 247 million surface acres, and 700 million subsurface (mineral) acres (together "public lands" or "BLM lands"). ${ }^{57}$ The bulk of this acreage is located in the western U.S., primarily in Alaska, Arizona, California, Colorado, Idaho, Montana, Nevada, New Mexico, Oregon, Utah, and Wyoming. In the eastern U.S., BLM manages approximately forty million acres of subsurface mineral estate and 30,000 surface acres, spread across thirty-one states.

BLM's management of public lands is governed by the Federal Land Policy and Management Act ("FLPMA"), 58 which requires it to apply the principle of "multiple use," such that land is "utilized in the combination that will best meet the present and future needs of the American people." 59 FLPMA requires BLM to "develop, maintain, and, when appropriate, revise land use plans which provide by tracts or areas for the use of public lands." ${ }^{60}$ Land use plans, also referred to as Resource Management Plans ("RMPs"), 61 "form the basis for every action and approved use on the public lands" 62 and are used by BLM to, among other things, "[a]llocate resources and determine appropriate multiple uses for the public lands." 63 


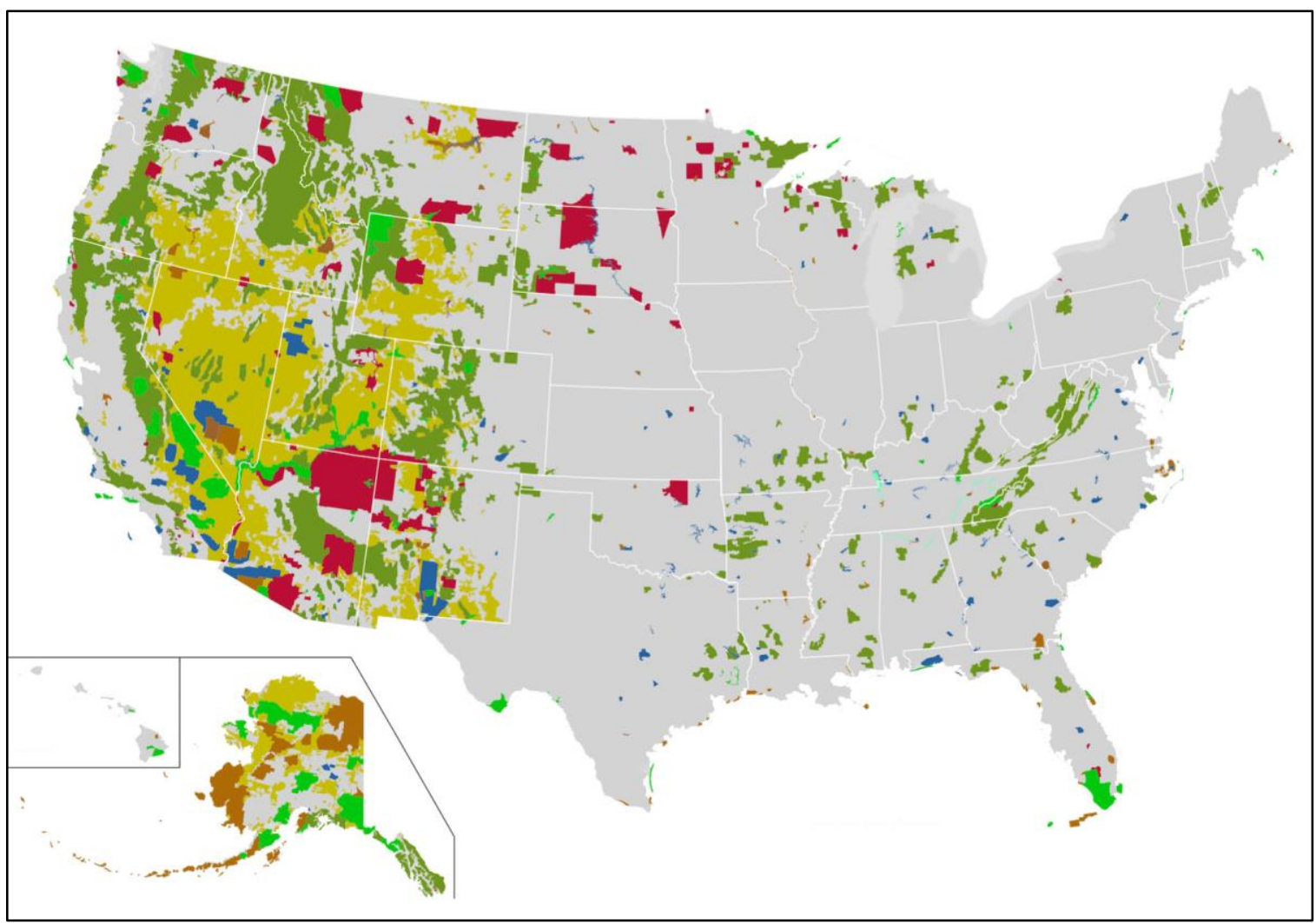

FIGURE 1: MAP OF FEDERAL LAND IN THE U.S.

(AREAS SHADED IN YELLOW ARE MANAGED BY BLM ${ }^{64}$ )

The development of an RMP constitutes a "federal action" for the purposes of section 7 of the ESA. BLM will, therefore, consult with FWS under section 7(a)(2) prior to issuing a new RMP. Consultation must be re-initiated whenever BLM proposes to revise or amend the RMP. ${ }^{65}$ Reinitiation of consultation is also required when additional species are listed as threatened or endangered or if significant new information becomes available suggesting there is a need to reevaluate the effects of the RMP. 66

Consultation on RMPs is governed by a Memorandum of Agreement (MOA) executed on August 30, 2000 between BLM, FWS, NMFS, and the Forest Service. ${ }^{67}$ Under the MOA, consultation on any new, revised, or amended RMP must be undertaken on a programmatic basis. ${ }^{68}$ Through the programmatic consultation, FWS and BLM agree on conservation measures designed to mitigate any adverse effects on listed species, resulting from development under the plan. ${ }^{69}$ Provided that subsequent developments incorporate the conservation measures, they will be eligible for streamlined review. ${ }^{70}$ 


\section{(A) Energy Development on BLM Lands}

In its RMPs, BLM specifies appropriate uses for public lands, and identifies tracts suitable for each use. Consistent with the multiple use principle established in FLPMA, BLM manages public lands for a variety of uses, including energy development. Approximately one-third of all domestically produced energy currently originates from public lands. ${ }^{71}$ This figure is expected to increase in coming years, driven primarily by an expansion in renewable energy production, particularly from solar and wind facilities. It is estimated that twenty-three million acres of BLMmanaged public land have solar energy potential and twenty-million acres have wind energy potential. ${ }^{72}$ BLM lands are also thought to overlie approximately eight billion barrels of oil and 201 trillion cubic feet of gas. ${ }^{73}$

Private parties may develop energy projects on public lands, after obtaining a permit or other authorization from BLM. ${ }^{74}$ For most projects this authorization takes the form of a right of way ("ROW"). A ROW is the privilege of passing over or through land owned by another person or entity. FLPMA authorizes BLM to issue ROW's over public lands for renewable energy projects, such as solar and wind generating systems. ${ }^{75} \mathrm{BLM}$ also has authority to permit the development of federally-owned onshore oil and gas resources under the Mineral Leasing Act. ${ }^{76}$

\section{(B) BLM's Role in Oil and Gas Development}

BLM is authorized to lease public land for oil and gas development under section 14 of the Mineral Leasing Act. ${ }^{77}$ BLM identifies areas suitable for leasing in its RMPs. ${ }^{78}$ Land within the identified areas may be nominated for leasing by any interested person by sending written notice to the relevant BLM State Office. ${ }^{79}$ The State Office must then conduct a review to confirm that the land is still suitable for leasing and, if so, may sell leases. ${ }^{80}$ Prior to the sale, the State Office must consult with FWS under section 7 of the ESA if listed species are likely to be affected. There is no single, nationally-uniform approach to consultation on lease sales. Rather, each State Office has developed its own consultation procedures.

Based on discussions with agency staff, we understand that most BLM State Offices do not consult on individual lease sales, where consultation has already occurred on the applicable RMP, and leasing is to occur in accordance with that RMP. The State Offices take the view that the act of leasing does not, by itself, have any effect on listed species. Although the grant of a lease confers on the lessee a right to develop oil and gas resources on the land, prior to undertaking any development, the lessee must obtain a separate authorization in the form of an application for permit to drill ("APD"). It is, therefore, the APD (not the lease) which authorizes development. At the time of the lease sale, the exact nature, location, and timing of development is not yet known. Without this information, the effects of development are difficult to quantify,

13 | Protecting Species or Endangering Development | August 2016 
and can only be assessed at a high level. A detailed assessment of effects is, therefore, typically left until the lessee requests an APD.

In several states, including Colorado, New Mexico, and Wyoming, consultation is only undertaken on lease sales that give rise to additional effects not considered during review of the applicable RMP. This may occur where:

- the land covered by the lease sale contains habitat for species which were listed after issuance of the RMP; or

- the lease sale does not comply with any conditions specified in, or is otherwise inconsistent with, the RMP.

Consultation on lease sales may also be required if new information regarding listed species becomes available after issuance of the RMP. BLM is currently in the process of updating its RMPs, many of which are over twenty years old. Until the updates are completed, BLM State Offices may have to routinely consult on individual lease sales, particularly those conducted under older RMPs. One example is the Carlsbad RMP, covering 2.7 million acres in southeastern New Mexico, which was issued in 1988. Recognizing that significant changes have occurred since this time, rather than relying on the RMP consultation, BLM's Carlsbad Field Office typically consults on lease sales individually. Such consultations generally proceed on an informal basis, with FWS undertaking a simplified review, wherein it merely confirms that the lease contains stipulations to protect listed species. ${ }^{81}$

A similar approach is followed in Utah. BLM's Utah State Office consults, generally on an informal basis, on each lease sale. Consultation is tiered to the previous programmatic consultation on the applicable RMP. As part of the tiered consultation, FWS seeks to confirm that stipulations relating to threatened and endangered species have been included in the lease. ${ }^{82}$ 
Case Study 1: November 2013 Oil and Gas Lease Sale in Central Utah

- Proposed Action: BLM sale of leases with respect to 82 parcels of land, covering 143,981 acres in Carbon, Duchesne, Emery, and Uintah Counties in Utah, for oil and gas development.

- Species Affected:

○ 5 plants: Graham's penstemon (Penstemon grahamii), Uinta Basin hookless cactus (Sclerocactus wetlandicus), Pariette cactus (Sclerocactus wetlandicus), Wright fishhook cactus (Sclerocactus wrightiae), and San Rafael cactus (Pedopcactus despainii)

- 1 bird: Mexican spotted owl (Strix occidentalis lucida)

- 4 fish: Colorado pikeminnow (Ptychocheilus Lucius), humpback chub (Gila cypha), bonytail chub (Gila elegans), and razorback sucker (Xyrauchen texanus)

- Type of Consultation: Informal. Consultation tiered to previous programmatic consultation on the RMPs issued by BLM's Utah State Office.

- Length of Consultation: 13 days (from receipt of the request for consultation $(11 / 20 / 13)$ to issuance of the concurrence letter (12/2/13)).

- Pre-consultation Discussions: Minimal. BLM typically provides FWS with basic information on the lease sale 9 months in advance and supplies a copy of its draft EA 6 months in advance.

- $\quad \boldsymbol{F W S}$ Determination: The lease sale is not likely to adversely affect listed species.

- Reasons for Determination: The sale documents will incorporate lease notices, informing the lessee that the parcel(s) covered by the leases may contain habitat for listed species and outlining conservation measures to protect species, which may be imposed on future developments.

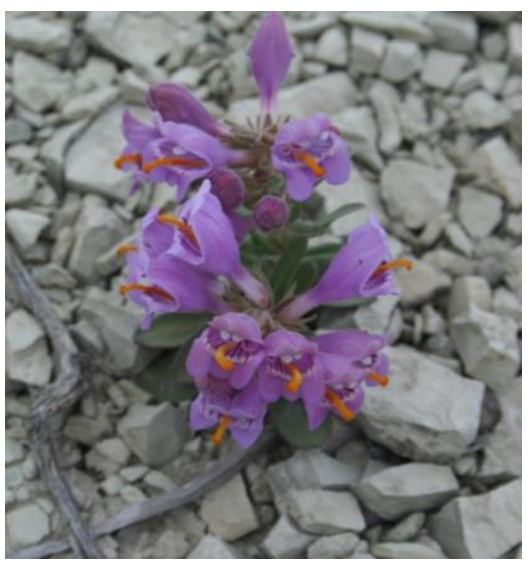

Graham's Penstemon

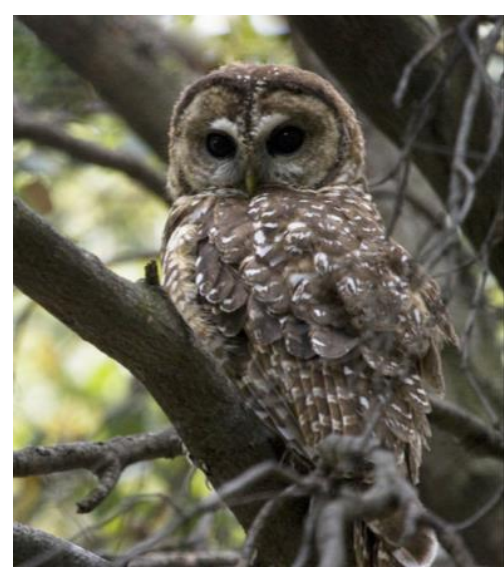

Mexican Spotted Owl

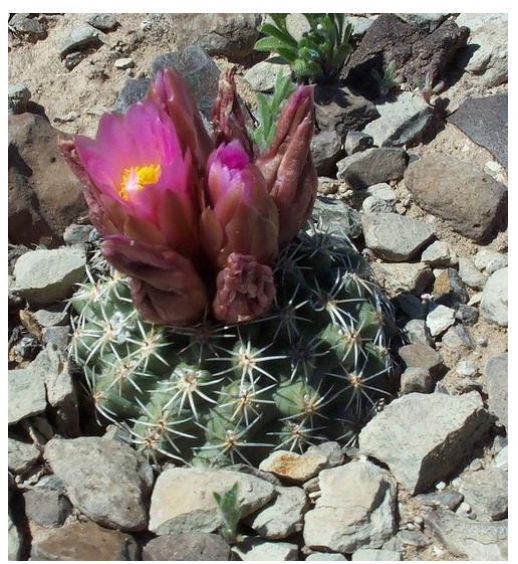

Pariette Cactus

15 | Protecting Species or Endangering Development | August 2016 


\section{(C) BLM's Role in Renewable Energy Development}

Under section 501(a)(4) of FLPMA, BLM may grant ROWs over public lands, authorizing use of that land for "systems for generation, transmission, and distribution of electric energy," including renewable generating facilities. BLM has, to date, permitted thirty-three utility scale solar energy projects with a combined capacity of 9,278 MW.83 BLM has also authorized thirtynine wind energy projects with a combined capacity of 5,557 megawatts ("MW") and over 100 wind energy testing facilities. ${ }^{84}$

\section{DESERT RENEWABLE ENERGY CONSERVATION PLAN}

The Desert Renewable Energy Conservation Plan ("DRECP") is a collaboration between BLM, the California Energy Commission, FWS, and the California Department of Fish and Wildlife that "seeks to facilitate renewable energy development in appropriate places in the desert while conserving these other resources and uses." The DRECP applies to all types of renewable energy projects, such as wind, solar, and geothermal, undertaken in desert areas of California. Approximately 22.5 million acres of federal and non-federal California desert land comprise the DRECP area.

The DRECP identifies and maps out areas that are best suited for renewable energy development (referred to as "Development Focus Areas") and areas suited to longterm natural resource conservation. In developing the DRECP, BLM released a Proposed Land Use Plan Amendment ("LUPA") that covers ten million acres of public lands in the DRECP area. The LUPA would amend the RMP for the California Desert Conservation Area related to natural resource conservation and energy development.

FWS issued its PBO on the DRECP early this year, although it has not been released to the public. According to representatives from FWS, the PBO "ultra streamlines" the consultation process for projects located within Development Focus Areas. - The PBO potentially approves such projects without the need for formal consultation.

\section{SOLAR ENERGY DEVELOPMENT ON PUBLIC LANDS}

Prior to 2009, BLM had not permitted any solar energy projects on public lands. Since this time, however, federal policies to encourage domestic renewable energy production, such as the Energy Policy Act of 2005 and American Recovery and Reinvestment Act, have fueled solar energy development. Since 2009, BLM has approved approximately thirty-three utility-scale solar 
energy projects on public lands. Federal tax incentives unleashed a wave of interest in solar energy development on public land. Agency staff we spoke to described the early interest like a "gold rush."

In the early years of the solar energy gold rush, BLM did not have any policy or guidance regarding the public lands suitable for solar development. BLM responded to development applications on a case-by-case basis without a formalized decision process or overarching plan to guide solar energy projects into areas that would have less impact on the environment. Due to the lack of planning, many early projects were located in ecologically sensitive areas. The backlash from approval of these projects was often intense, with many environmental groups highly critical of the damage utility-scale solar projects cause to sensitive desert ecosystems.

Recognizing the need for a systemized process, BLM created a Solar Energy Program that spans six western states with solar energy potential: Arizona, California, Colorado, Nevada, New Mexico, and Utah. ${ }^{85}$ As part of the program, BLM categorized certain areas of public land that are excluded from solar energy development and created solar energy zones ("SEZ's") where developers are incentivized to locate projects through more efficient permitting procedures. BLM defines a SEZ as "an area within which the BLM will prioritize and facilitate utility-scale production of solar energy and associated transmission infrastructure development." 86

To develop and implement the Solar Energy Program, BLM amended RMPs in those states affected by the Program. As discussed above, before amending an RMP, BLM must consult with FWS under the ESA. On February 12, 2012, BLM requested initiation of formal programmatic consultation on the proposed Solar Energy Program, but discussions concerning the consultation had commenced in August 2009.87 Agency staff reported that FWS had discussions with BLM weekly during the formal consultation process. FWS's BO was based on these discussions, in addition to the programmatic EIS, BA and Conservation Assessment prepared by BLM.

On July 20, 2012, FWS issued a PBO concluding that the program is not likely to jeopardize the continued existence of seventeen listed species or destroy or adversely modify designated critical habitat for twelve of the species with critical habitat designations. Additionally, FWS concurred with BLM's determinations that the program is not likely to adversely affect five listed species or the critical habitat of two of these species. FWS determined that "the selection of Solar Energy Zones (SEZs), exclusion of certain areas from eligibility for solar development, application of design features to all solar developments that will occur, and the review process applicable to development in variance areas outside SEZs are likely to contribute to the conservation of listed species." 88

17 | Protecting Species or Endangering Development | August 2016 


\section{WIND ENERGY DEVELOPMENT ON PUBLIC LANDS}

BLM has recently sought to encourage development of wind energy projects on public lands. In August 2006, BLM adopted a comprehensive Wind Energy Development Program ("WEDP”) to guide wind energy site testing and development projects in the western U.S., excluding Alaska. ${ }^{89}$ As part of the program, BLM amended fifty-two RMPs in nine states, ${ }^{90}$ to specify areas of public land in which future wind energy development may and may not be undertaken. In areas open to future development, BLM may grant ROWs for wind energy projects, under FLPMA. ROWs can also be granted for projects in other areas, but this may require amendment of the applicable RMP, to ensure that development conforms therewith. ${ }^{91}$

In developing the 2006 WEDP, BLM consulted with FWS, pursuant to section 7 of the ESA. FWS found that future development under the WEDP may adversely affect nine endangered and threatened species, ${ }^{92}$ but is unlikely to jeopardize their continued existence, as developers will be required to comply with best management practices ("BMPs"). ${ }^{93}$ The BMPs were developed by BLM in 2006 as part of the WEDP. ${ }^{94}$ In 2008, BLM issued revised BMPs to provide updated guidance for wind energy development. ${ }^{95}$ The revised BMPs deal with, among other things:

- the conduct of studies to identify listed species and critical habitat in the project area;

- designing projects so as to minimize or mitigate impacts to species and habitat;

- avoiding project activities in sensitive habitats and certain other areas where species are present;

- minimizing the total area disturbed by the project and ensuring reclamation of disturbed areas;

- limiting of vehicle and/or equipment use within the project area; and

- restricting the timing of construction and other project activities. ${ }^{96}$

Additional strategies for reducing the impacts of wind energy development are set out in guidelines published by FWS in March 2012. ${ }^{97}$ The FWS Land-Based Wind Energy Guidelines ("FWS Guidelines") are intended to assist developers to identify species that may be impacted by a proposed project and quantify the potential risks to species from the project. In the Guidelines, FWS also provides advice to developers on project siting, design, construction, and operation, so as to mitigate species risks. ${ }^{98}$ To this end, the FWS Guidelines outline fifty-one BMPs which, if implemented, should avoid or reduce the impacts to species. Compliance with the BMPs is voluntary and does not relieve the developer of any obligations he/she/it may have under the

18 | Protecting Species or Endangering Development | August 2016 
ESA. ${ }^{99}$ FWS will, however, consider a developer's efforts to comply with the BMPs when assessing what action (if any) to take in respect of a violation of the ESA. ${ }^{100}$

\section{Managing the Impacts of Energy Development on BLM Land}

Energy development on BLM lands may have a range of adverse effects, including on threatened and endangered species. The species affected will vary depending on the nature of the project and its location. Despite this, however, both conventional (i.e., fossil fuel) and renewable (i.e., wind and solar) energy projects often raise similar issues. For example, both conventional and renewable energy projects often lead to:

- land clearing, which may result in habitat fragmentation, leading to species decline;

- increased water use, which may lead to reduced stream flows, contributing to higher temperatures and/or pollutant concentrations, and adversely affecting fish species;

- noise pollution caused by human activity, which may lead wildlife to avoid the area and thereby interfere with essential life stages (e.g., breeding and feeding);

- additional vehicle traffic, which places wildlife at greater risk of death or injury due to collisions; and

- changes in predator-prey dynamics, as garbage left behind by humans attracts scavengers and birds of prey.

Although raising similar issues, renewable energy projects often have more widespread effects, compared to other forms of energy development. For example, solar energy projects often have greater impacts on species habitat than oil and gas development. Whereas land clearing for oil and gas development is typically confined to a fairly small area (around five acres), utility-scale solar projects can require the clearing of hundreds or even thousands of acres. The Genesis Solar Energy Project and Desert Sunlight Project in southern California, for example, each required the clearing of over 4,000 acres. Within the cleared area, solar panels may cover virtually the entire surface of the land, preventing its use by wildlife. This is less of an issue in wind energy projects, which generally disturb smaller areas. Those projects can, however, lead to significant disturbance of air space. As a result, they may affect birds and bats to a greater extent than other types of projects.

Further information on the impacts of different types of energy projects is provided below.

19 | Protecting Species or Endangering Development | August 2016 


\section{(A) Potential Impacts of Oil and Gas Development}

Oil and gas development involves four key stages, namely: (1) exploration, (2) drilling, (3) production, and (4) abandonment. ${ }^{101}$ During the exploration stage, developers conduct seismic and other studies to identify rock formations containing hydrocarbon deposits, and engage in exploratory drilling to assess the size of those deposits. ${ }^{102}$ After locating an economically recoverable deposit, the developer will drill one or more wells to extract oil and gas, ${ }^{103}$ and then purify the materials for sale. ${ }^{104}$ Finally, after all oil and gas has been extracted, the developer will plug and abandon the well. 105

These activities may affect wildlife and plants in a variety of ways. As an example, during oil and gas exploration, developers may use explosives or vibrating plates to generate seismic waves, which may cause wildlife to avoid the area, and thereby interfere with essential behaviors. At later stages of development, extraction of oil and gas may result in land clearing, leading to fragmentation of wildlife habitat, and/or destroying plants. Increased human and vehicle activity during extraction may also lead to wildlife and plant deaths.

The extent of these and/or other impacts from oil and gas development is highly site specific and may vary depending on the location of the project and the species' found there. ${ }^{106}$ Impacts can be mitigated through careful project design, including by:

- limiting seismic surveys to areas away from occupied habitat;

- restricting the times during which seismic surveys and other activities are conducted;

- developing well sites away from critical breeding, nesting, and other areas;

- locating well sites so as to maintain large blocks of natural habitat;

- installing housing around noisy equipment to reduce disturbance to wildlife;

- avoiding construction of new infrastructure by using existing roads to access well sites;

- minimizing the amount of vehicle traffic and controlling vehicle speeds;

- reducing human activity at or near the well site through remote monitoring; and

- improving habitat through reclamation of plugged and abandoned wells. ${ }^{107}$

\section{(B) Potential Impacts of Solar Energy Development}

In a utility-scale solar energy project, solar power is generated, fed into the utility grid, and sold to wholesale utilities. There is no standardized definition of what qualifies as a utility-scale project. They can differ in technology, amount of electricity produced, and size, although most 
utility-scale solar projects require a significant amount of acreage. Such projects generally use one of two technologies, namely:

(1) concentrating solar power ("CSP") technologies, which use sunlight to heat a fluid and drive steam turbines or engines that create electricity; 108 and

(2) photovoltaic ("PV") technologies, which convert energy from the sun directly into electricity by capturing photons from the sun, and then using that energy to drive an electric current on a solar panel. 109

PV technologies have been gaining popularity in recent years and are being used in most new utility-scale solar energy projects. In the past, however, utility-scale solar projects were often developed using CSP technologies. Commonly used technologies included:

- CSP trough systems(also referred to as parabolic trough systems) which use curved reflectors that follow the sun throughout the day, with the sunlight used to heat oil in pipes along the center of the reflectors, ${ }^{110}$ which is then used to boil water and make steam, to power a turbine or engine to generate electricity. ${ }^{111}$

- CSP tower systems (also referred to as power towers or central receivers) which use a field of mirrors that individually track the sun on two axes and redirect sunlight to a receiver at the top of a tower, where it heats a fluid (usually molten salt), ${ }^{112}$ which is used to make steam. ${ }^{113}$

Several of the early consultations reviewed for this study, dating from 2010 and 2011, involved projects designed to use CSP trough or tower systems. Some of those projects were subsequently re-designed to make use of PV technologies. All of the projects subject to consultation in or after 2012 used PV technologies. Both CSP and PV solar energy systems require a significant amount of land for construction and can, therefore, disturb sensitive ecosystems and wildlife habitat. During construction, large tracts of habitat may be cleared to enable installation of solar panels and associated facilities, such as transmission lines. These lines may attract predators to the area and are often used as nesting and perching sites by ravens and other birds of prey. Access points for transmission lines and roads may lead to the spread of invasive plants which can compromise the health of wildlife. Additionally, wildlife can be injured or killed during construction from vehicular traffic.

Species impacts may continue after the completion of construction, throughout the operating life of the solar energy facility. The operation of CSP facilities, for example, may require large amounts of water and thereby adversely affect fish species. Both CSP and PV facilities may also affect water dependent species of birds, who may mistake the mirrored surface of solar panels for water, and collide with them.

21 | Protecting Species or Endangering Development | August 2016 


\section{(C) Potential Impacts of Wind Energy Development}

Wind energy systems convert the kinetic energy of wind into mechanical power. They are comprised of a number of turbines, made up of two or three propeller-like blades, attached to a rotor hub and nacelle, sitting atop a tall tower. ${ }^{114}$ When wind blows past a turbine, the blades rotate, causing a shaft inside the nacelle to spin, thereby generating electricity. ${ }^{115}$ To take advantage of faster and more consistent wind at high altitudes, most turbines have long blades, often exceeding 116 feet in length, which are placed on towers up to 325 feet tall. ${ }^{116}$ Each turbine is connected, typically via an underground power collection system, to the high voltage transmission grid. 117

The construction and operation of wind energy systems may have adverse impacts on wildlife, particularly small birds and bats, which may be killed or injured as a result of collisions with wind turbines and other infrastructure (e.g., transmission lines and towers). ${ }^{118}$ Bat fatalities have also occurred due to internal hemorrhaging caused by sudden drops in air pressure near rotating turbine blades. ${ }^{119}$ Fatality rates vary significantly between facilities, ranging from three to five birds per MW per year, and up to thirty bats per MW per year. ${ }^{120}$ The number of fatalities can be reduced through careful facility design, including by:

- $\quad$ siting wind turbines away from key bird migration paths and other high-activity sites; ${ }^{121}$

- turning off lights on turbines and other facilities at night to avoid attracting birds; ${ }^{122}$

- using radar or GPS systems to detect approaching birds and adjust turbine operation;123

- curtailing turbine blades at times of low wind speed when bats are most likely to fly; ${ }^{124}$ and

- installing acoustic transmitters which generate a high-frequency noise to deter bats. ${ }^{125}$

Birds, bats, and other species may also be indirectly affected by wind energy development, including through habitat degradation from land clearing and increased human activity, which may also cause species to avoid the area. ${ }^{126}$ This may continue after humans have left the area, with many species exhibiting behavioral avoidance of tall structures, such as wind turbines and transmission towers. Species that do not avoid the area may experience increased predation as turbines and associated infrastructure are often used as perches by raptors and other birds of prey. ${ }^{127}$

22 | Protecting Species or Endangering Development | August 2016 


\section{Energy Projects Reviewed Under the Endangered Species Act}

This study presents data on 179 consultations, relating to energy projects authorized by BLM, which were undertaken between FY2010 and FY2014. We focused on energy projects in the seventeen westernmost states, from North Dakota south to Texas and West to Hawaii, where the majority of BLM acreage is situated. Due to the relatively small amount of BLM acreage in eastern states, we did not analyze any projects in the eastern half of the country. Nor did we analyze projects undertaken in Alaska.

\section{(A) Methodology}

To obtain data on recent section 7 consultations, we filed a series of information requests with FWS, under the Freedom of Information Act ("FOIA"). ${ }^{128}$ The first request sought a list of all energy projects proposed to be authorized by BLM that were subject to consultation between FY2010 and FY2014. Consistent with the geographic scope of the study, as described above, the request only sought data relating to energy projects in FWS regions 1, 2, 6, and 8 (see Figure 2 below).

FWS provided basic information relating to each project extracted from TAILS. ${ }^{129}$ All FWS Regional Offices have been required, since October 2006, to record

\section{KEY FINDINGS}

- Total number of consultations - 179

○ Formal consultations -54

- Informal consultations - 125

- Oil and gas project consultations - 143

- Share or percentage of total oil and gas projects on BLM land - 10\%

- Solar energy project consultations - 27

- Share or percentage of total solar energy projects on BLM land - 82\%

- Wind energy project consultations - 9

- Share or percentage of total wind energy projects on BLM land - 70\%

both formal and informal consultations in TAILS. ${ }^{130}$ For each consultation, the lead office must create a separate record in TAILS. Each record is assigned a unique activity code, which reflects the date on which the request for consultation was received, as well as the office assigned to handle that request. 


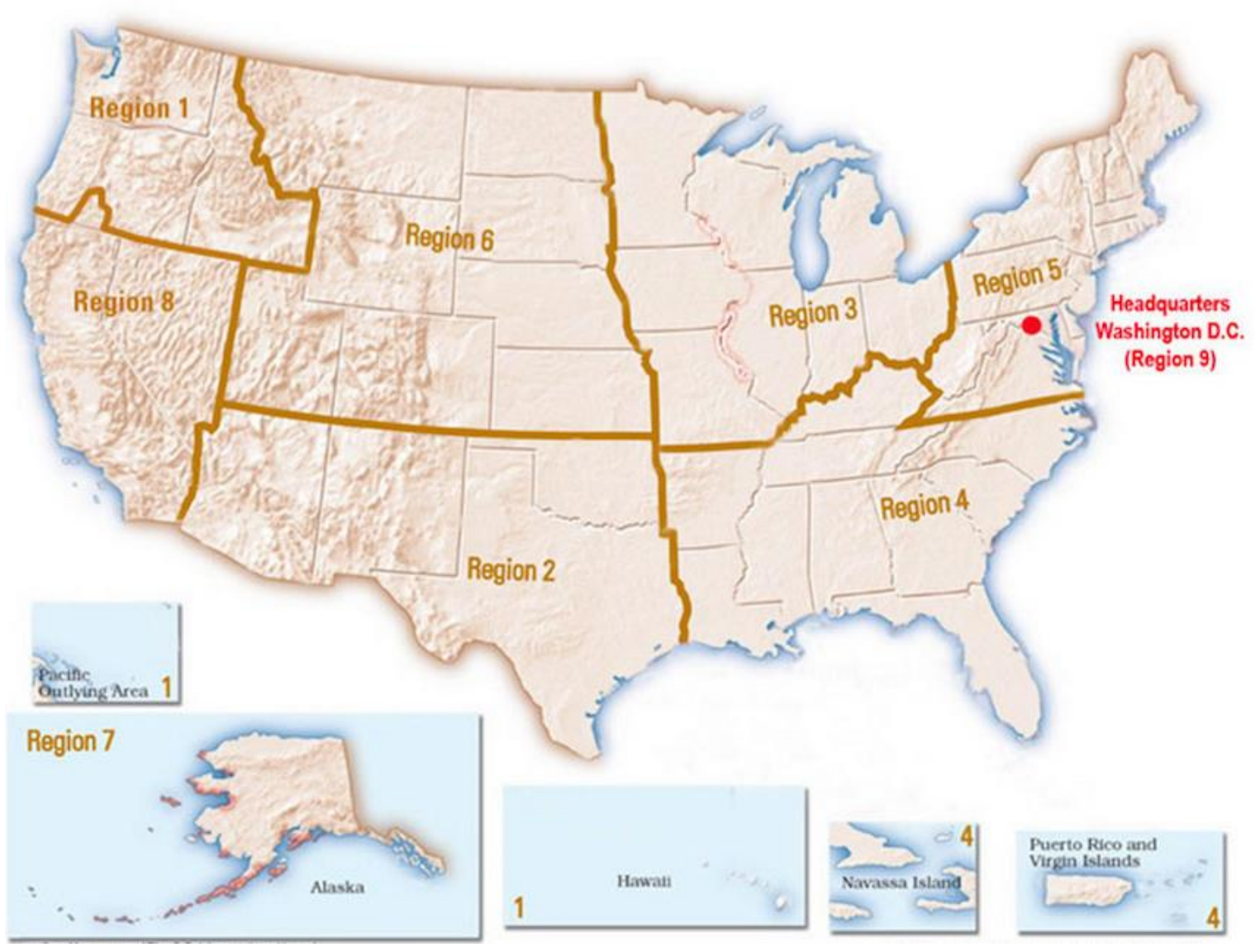

FIGURE 2: U.S. FISH AND WILDLIFE SERVICE REGIONS ${ }^{131}$

The TAILS record for each section 7 consultation must include specified information, including a description of the activity to which the consultation relates, the lead agency for the activity, the species affected by the activity, the type of consultation undertaken, the lead region and office for the consultation, and the conclusion date of the consultation. The TAILS record may also include other information relating to the consultation, such as the findings of any BA and/or $\mathrm{BO}$ issued therefor.

In response to our information request, FWS provided a list of consultations relating to energy projects on BLM lands, which were undertaken between FY2010 and FY2014. FWS compiled the list by searching TAILS for entries meeting the following criteria:

- Action / Work Type = Oil, gas, wind, or solar energy;

- FWS Region $=1,2,6$, or 8;

- $\quad$ Conclusion Date $=10 / 01 / 2009-09 / 30 / 2014$ (inclusive); and

- $\quad$ Lead Agency = BLM 
This search may not have identified all consultations involving energy projects on BLM lands. Potentially excluded projects include:

- Projects requiring approval from multiple agencies: FWS staff indicated that, where a project requires the approval of BLM and another federal agency, that agency may be recorded as the lead agency. Projects so recorded would have been excluded from the above search as the third requirement was not met.

- Projects appended to a previously issued PBO: FWS staff indicated that projects not subject to consultation on an individual basis, such as those appended to a previous $\mathrm{PBO}$, are generally not recorded in TAILS.

We have not been able to determine the number of consultations erroneously omitted from the list provided by FWS. Based on data published by BLM, we have identified nine consultations involving renewable energy projects (eight solar and one wind) which occurred between FY2010 and FY2014, but do not appear on the FWS list. For completeness, we have included those consultations in our analysis. The analysis may, however, be missing some consultations relating to oil and gas development.

It is also possible that the FWS list may erroneously include some projects which did not involve energy development on federal lands. The list is based solely on records from TAILS, which are created by FWS staff. With over 1,300 staff recording data in TAILS, some level of human error is to be expected. A 2015 study of over 88,000 TAILS records found various errors, including in the description of the projects, and the start and end dates of consultation. ${ }^{132}$ There may be similar errors in the list used for this study.

The list provided by FWS included basic information about each consultation, including the activity code and description, species affected, type of consultation, lead office, and conclusion date, as recorded in TAILS. To supplement this information, we requested copies of any BOs or concurrence letters issued therefor, from FWS through a FOIA request. After reviewing the documentation provided by FWS, and through discussions with agency staff, we identified several errors in the original list based on TAILS, namely:

- 2 listed consultations related to a single project;

- 9 consultations related to connected action projects, which occurred entirely on privately owned land, but required BLM approval for off-site facilities;

- 1 consultation involved the Bureau of Indian Affairs ("BIA") (not BLM); and

- 3 consultations were closed without issuance of a $\mathrm{BO}$ or concurrence letter.

Based on the information provided by FWS, we selected a small number of consultations for further study, focusing on those involving the most complex issues. For example, many of the 
selected consultations involved species which are generally considered difficult to manage, including because impacts thereto cannot be easily assessed, and/or mitigation of such impacts is particularly onerous. For each of the selected consultations, we interviewed agency staff and, where possible, industry representatives to gain a better understanding of how the process played out in practice. Many of the findings reported in this study are based solely on those interviews.

\section{Oil and gas projects:}

\section{CASE STUDIES}

1. November 2013 oil and gas lease sale in central Utah

2. Programmatic consultation on small oil and gas projects in southern California

3. Whitewater Unit Master Development Plan for oil drilling in western Colorado

4. Black Hills Western Properties Master Development Plan for oil and gas drilling in western Colorado

5. Crown Energy Partners' drilling of thirteen gas wells in south west Wyoming

6. Newfield Production's 20-acre infield development in north east Utah

7. Three Forks Resources' oil well development in central Wyoming

8. PetroQuest Energy's oil drilling in north eastern Oklahoma

\section{Solar energy projects.}

9. Ivanpah Solar Electric Generating System in southern California

10. Stateline Solar and Silver State South Projects in California

11. Four Solar Energy Projects in the Dry Lake Solar Energy Zone in Nevada

\section{Wind energy projects:}

12. Tule Wind Project in southern California

13. Graham Pass Wind Project in California

(A map showing the location of these projects is found on page 27.) 


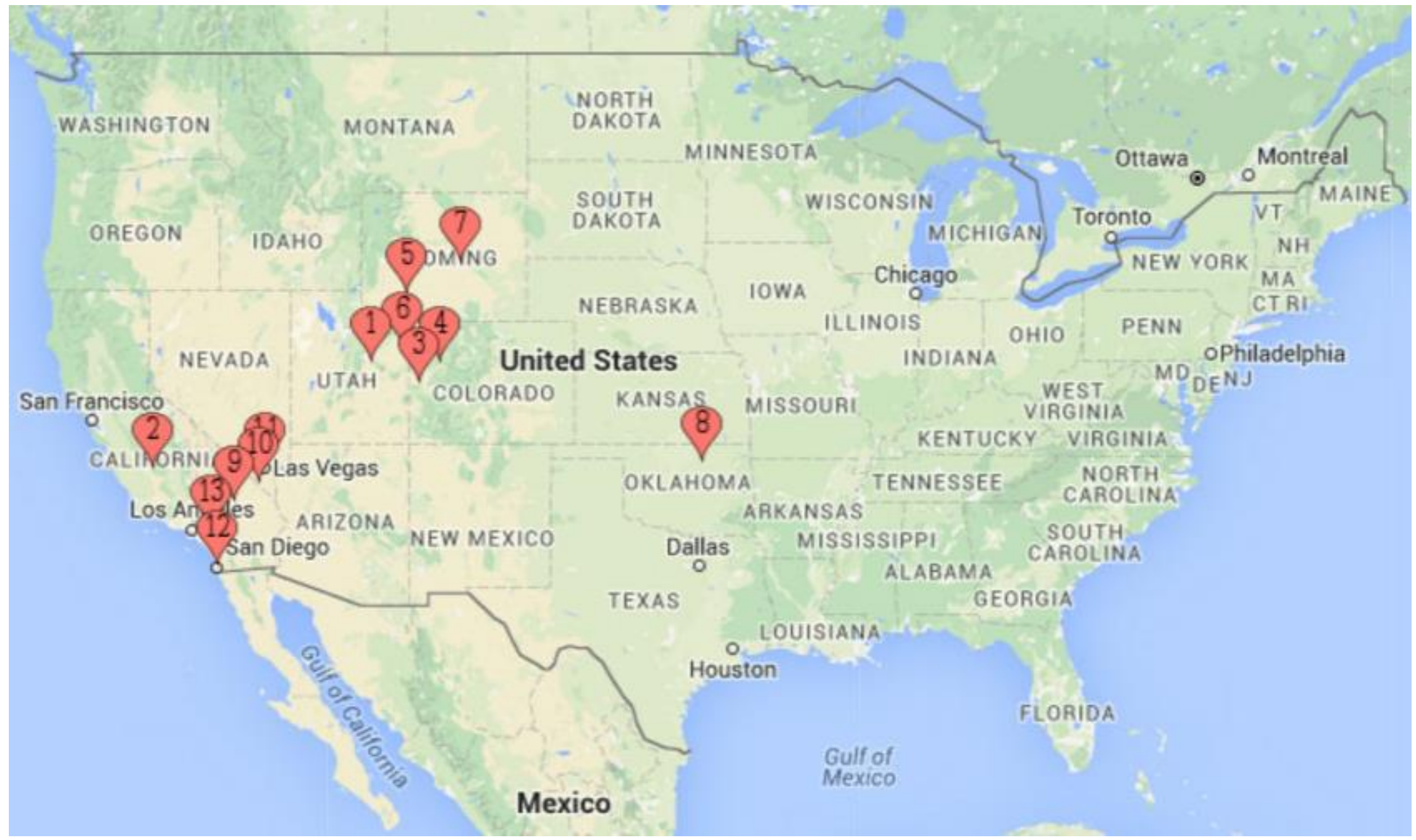

FIGURE 3: MAP SHOWING LOCATION OF PROJECTS FEATURED AS CASE STUDIES (NUMBERS CORRESPOND TO THE LIST ABOVE) 


\section{(B) Consultations Relating to Energy Projects on BLM Lands}

We used the following approach to calculate the total number of consultations relating to energy projects on BLM lands:

Total consultations $=184$ consultations recorded in TAILS plus 9 missing renewable energy project consultations less 9 consultations relating to connected action projects less 3 incomplete consultations less 1 duplicated consultation less 1 consultation not involving BLM

Based on that calculation, a total of 179 consultations were undertaken with respect to energy projects on BLM lands, from F2010 to FY2014. Table 1 below provides a breakdown of the consultations by region and year.

TABLE 1: ENERGY PROJECT CONSULTATIONS FY2010 - FY2014 (BY REGION)

\begin{tabular}{|c|c|c|c|c|c|c|}
\hline & & & & & \\
\hline & & Region 1 & Region 2 & Region 6 & Region 8 & All Regions \\
\hline \multirow{2}{*}{2010} & Formal Consultation & 0 & 0 & 8 & 12 & 20 \\
\hline & Informal Consultation & 0 & 2 & 7 & 6 & 15 \\
\hline \multirow{2}{*}{2011} & Formal Consultation & 0 & 0 & 7 & 3 & 10 \\
\hline & Informal Consultation & 0 & 2 & 22 & 0 & 24 \\
\hline \multirow{2}{*}{2012} & Formal Consultation & 0 & 1 & 7 & 4 & 12 \\
\hline & Informal Consultation & 0 & 9 & 20 & 2 & 31 \\
\hline \multirow{2}{*}{2013} & Formal Consultation & 0 & 0 & 6 & 4 & 10 \\
\hline & Informal Consultation & 0 & 9 & 20 & 2 & 31 \\
\hline \multirow{2}{*}{2014} & Formal Consultation & 0 & 0 & 2 & 0 & 2 \\
\hline & Informal Consultation & 0 & 4 & 19 & 1 & 24 \\
\hline \multicolumn{2}{|c|}{ Five-Year Total } & 0 & 27 & 118 & 34 & 179 \\
\hline
\end{tabular}

As Table 1 shows, almost two-thirds (sixty-six percent) of the consultations analyzed occurred in FWS region 6. This is likely due to the size of region 6 , which consists of eight states, with a combined area of over 732,000 square miles. Many of those states have significant energy development. Indeed, five of the states are among the top twenty energy producers nationwide, and three are within the top ten producers. Other FWS regions also include states with 
significant energy production. Region 2, for example, includes the major energy producing states of New Mexico, Oklahoma, and Texas. Notably however, the total area of region 2 is significantly smaller than that of region 6 , and the majority of land in region 2 is in state or private ownership, with little federally-owned land (see Figure 2 above).

In most regions, there has been an upward trend in the number of consultations over time. This is consistent with the expansion of energy production, particularly renewable energy production, on BLM lands over the last five years. BLM had authorized just 556 MW of wind energy and no solar energy on its lands prior to 2010. Over the subsequent five years, BLM permitted eleven new wind projects with a combined capacity of 4,767 MW and twenty-nine solar energy projects with a combined capacity of 8,271 MW.133 All of these projects were located in FWS regions 1, 2, 6, and $8 .{ }^{134}$ These regions have also seen significant oil and gas development in recent years, with BLM approving the drilling of 19,977 wells, over the period from FY2010 to FY2014.135

Given the above, it is perhaps unsurprising that the majority of recent section 7 consultations relating to energy projects involved oil and gas development. The number of consultations undertaken by FWS for each type of project is shown in Table 2 below. ${ }^{136}$

TABLE 2: ESA CONSULTATIONS FY2010-FY2014 (BY TYPE OF PROJECT)

\begin{tabular}{|l|l|l|l|l|}
\cline { 3 - 5 } \multicolumn{2}{c|}{} & $\begin{array}{l}\text { Oil / Gas } \\
\text { Exploration }\end{array}$ & $\begin{array}{l}\text { Wind Energy } \\
\text { Development }\end{array}$ & $\begin{array}{l}\text { Solar Energy } \\
\text { Development }\end{array}$ \\
\hline \multirow{3}{*}{ Region 1} & Formal Consultation & 0 & 0 & 0 \\
\cline { 2 - 5 } & Informal Consultation & 0 & 0 & 0 \\
\hline \multirow{3}{*}{ Region 6 } & Formal Consultation & 0 & 0 & 1 \\
\cline { 2 - 5 } & Informal Consultation & 25 & 1 & 0 \\
\hline \multirow{3}{*}{ Region 8 } & Formal Consultation & 28 & 1 & 0 \\
\cline { 2 - 6 } & Informal Consultation & 88 & 0 & 0 \\
\cline { 2 - 6 } & Formal Consultation & 1 & 5 & 18 \\
\hline \multirow{2}{*}{ All Regions } & Formal Consultation & $\mathbf{2 9}$ & 2 & 8 \\
\cline { 2 - 6 } & Informal Consultation & $\mathbf{1 1 4}$ & $\mathbf{6}$ & $\mathbf{1 9}$ \\
\hline
\end{tabular}

Table 2 above reflects the number of unique consultations for each project category. This may not, however, reflect the number of individual projects reviewed. In some instances, FWS may consolidate two or more projects, which then become the subject of a single consultation. In other situations, multiple consultations may be undertaken in respect of a single project. This 
frequently occurs where a change in circumstances, such as a project modification, triggers reinitiation of consultation. ${ }^{137}$

\section{(C) Oil and Gas Projects Subject to Consultation}

As shown in Table 2 above, FWS conducted 143 consultations with respect to oil and gas development on BLM acreage between FY2010 and FY2014. The projects encompassed a variety of activities, including:

- lease sales, through which private operators lease public lands for oil and gas development;

- exploration projects, whereby a lease holder conducts seismic surveys and/or drills exploratory wells to locate oil and gas reserves;

- production operations, consisting of the drilling and completion of oil and gas wells and/or construction and operation of support facilities; and

- other actions, such as the construction and operation of facilities for processing, storing, and transporting oil and gas.

The majority of projects analyzed in this study involved the drilling of one or more oil and/or gas wells. ${ }^{138}$ Table 3 below provides a breakdown of well drilling by state. The table shows the total number of wells authorized to be drilled by BLM (taken from publicly available data). This is compared to the number of wells which were subject to consultation under the ESA. To calculate this number, we first identified energy projects involving oil and gas drilling, from FWS's TAILS records. For each of those projects, we reviewed the BO or concurrence letter issued by FWS, to determine how many wells were to be drilled. Where the number of wells was not specified in the BO or concurrence letter, we contacted the relevant FWS and BLM office to request that information.

TABLE 3: OIL AND GAS WELLS SUBJECT TO REVIEW UNDER THE ESA (NUMBER OF WELLS DRILLED)

\begin{tabular}{|l|l|l|l|l|l|}
\hline \multirow{2}{*}{ State } & \multirow{2}{*}{$\begin{array}{l}\text { Total number of } \\
\text { wells drilled on BLM }\end{array}$} & \multicolumn{4}{|l|}{ Individual Wells Reviewed by FWS } \\
\cline { 3 - 6 } & Lands & Formal Consultation & \multicolumn{2}{l|}{ Informal Consultation } \\
\cline { 3 - 6 } & & Number & Percentage & Number & Percentage \\
\hline California & 1,367 & 0 & $0.0 \%$ & 1 & $0.1 \%$ \\
\hline Colorado & 2,154 & 227 & $10.5 \%$ & 202 & $9.4 \%$ \\
\hline Montana & 195 & 0 & $0.0 \%$ & 0 & $0.0 \%$ \\
\hline Nevada & 22 & 0 & $0.0 \%$ & 0 & $0.0 \%$ \\
\hline New Mexico & 4,746 & 0 & $0.0 \%$ & 2 & $0.0 \%$ \\
\hline
\end{tabular}

30 | Protecting Species or Endangering Development | August 2016 


\begin{tabular}{|l|l|l|l|l|l|}
\hline \multirow{2}{*}{ State } & \multirow{2}{*}{$\begin{array}{l}\text { Total number of } \\
\text { wells drilled on BLM }\end{array}$} & \multicolumn{4}{|l|}{ Individual Wells Reviewed by FWS } \\
\cline { 3 - 6 } & Lands & Formal Consultation & \multicolumn{2}{l|}{ Informal Consultation } \\
\cline { 3 - 6 } & & Number & Percentage & Number & Percentage \\
\hline North Dakota & 988 & 0 & $0.0 \%$ & 24 & $2.4 \%$ \\
\hline Oklahoma & 100 & 0 & $0.0 \%$ & 42 & $42.0 \%$ \\
\hline Texas & 182 & 0 & $0.0 \%$ & 2 & $1.1 \%$ \\
\hline Utah & 3,798 & 445 & $11.7 \%$ & 339 & $8.9 \%$ \\
\hline Wyoming & 6,425 & 718 & $11.2 \%$ & 12 & $0.2 \%$ \\
\hline Total & $\mathbf{1 9 , 9 7 7}$ & $\mathbf{1 , 3 9 0}$ & $\mathbf{7 . 0} \%$ & $\mathbf{6 2 4}$ & $\mathbf{3 . 1} \%$ \\
\hline
\end{tabular}

The above figures suggest that just ten percent of oil and gas projects authorized between FY2010 and FY2014 were subject to consultation. There are several possible explanations for this, including:

- The sites best suited to oil and gas development may be located outside species habitat, reducing the potential impacts on listed species, and therefore making consultation unnecessary.

- Oil and gas developers may be purposely siting projects away from species habitat so as to avoid the need to consult.

- Federal agencies may be avoiding the consultation requirement by taking a narrow view of project effects.

It is not possible, based on the data analyzed in this study, to determine the relative significance of these factors. There is, however, some anecdotal evidence to support the first two explanations. Several government and industry representatives interviewed for this study reported that much of the oil and gas development to date has occurred outside species habitat. There were also reports that, prior to undertaking development, developers seek to identify any potential impacts on species and/or habitat and design their project so as to avoid those impacts.

\section{(D) Consultations Relating to Renewable Energy Projects}

As shown in Table 2 above, FWS undertook thirty-six consultations with respect to renewable energy projects between FY2010 and FY2014. Of those consultations, twenty-seven involved solar energy projects, and nine involved wind energy projects. The number of consultations may not, however, reflect the number of unique projects reviewed. Our analysis indicates that some projects were subject to multiple consultations, each of which is counted separately above. ${ }^{139}$ 
Conversely, some projects were consolidated under a single consultation, which is only counted once in the figures above. ${ }^{140}$

\section{SOLAR ENERGY PROJECTS SUBJECT TO CONSULTATION}

The list of energy project consultations compiled by FWS, based on its TAILS records, identified twenty-nine consultations relating to solar energy projects. Two entries related to the same consultation but in different regions. To avoid double counting, we removed the second entry. Data obtained from BLM indicates that there were eight additional solar energy project consultations not included on the TAILS list, taking the total to thirty-six. Of those consultations, nine related to connected action projects that occurred entirely on private lands, but required BLM approval for off-site facilities. As those projects did not involve development on public land, they have been excluded from this study, taking the total number of solar energy project consultations to twenty-seven consultations relating to solar energy projects. Twenty of those consultations were formal and eight were informal.

BLM records indicate that twenty-nine solar energy projects were permitted from FY2010 to FY2014. ${ }^{141}$ This includes two projects which were undertaken on tribal lands and ten connected action projects occurred on private lands. These projects were excluded from our study. Of the remaining seventeen projects, all but three were subject to consultation under the ESA. Fourteen projects (eighty-two percent of the total) underwent consultation.

\section{WIND ENERGY PROJECTS SUBJECT TO CONSULTATION}

The list of energy project consultations compiled by FWS, based on its TAILS records, identified eight consultations relating to wind energy projects. As explained above, data obtained from BLM indicates that there was one additional wind energy consultation not included on the list, taking the total to nine. After reviewing the BOs and concurrence letters issued by FWS, we determined that each consultation related to a unique project:

- five projects involved development of new wind energy facilities on public lands;

- three projects involved site testing and monitoring activities prior to new development; and

- one project involved operation and maintenance of switchyards to support existing facilities.

BLM records indicate that ten wind energy projects were permitted on public lands from FY2010 to FY2014.142 This includes three "connected action" projects that occurred on private lands but required BLM approval for off-site facilities. Those projects have, therefore, been excluded from this study. Of the remaining seven projects which occurred on public lands, all but two (seventy-one percent) were subject to consultation under the ESA.

32 | Protecting Species or Endangering Development | August 2016 


\section{Oil and Gas Project Consultations}

The majority of recent section 7 consultations, undertaken with respect to energy projects on BLM acreage, involved oil and/or gas development. The TAILS records obtained from FWS indicate that, between FY2010 and FY2014, 143 consultations were undertaken with respect to oil and gas projects on BLM acreage. Of those consultations, 114 (seventy-nine percent) were recorded in TAILs as informal, and thirty (twenty-one percent) as formal. After reviewing the BOs issued for each formal consultation, we determined that five were incorrectly entered in TAILS, and actually involved informal consultation. After correcting for those errors, there were twenty-four formal consultations, and 119 informal consultations.

None of the twenty-four formal consultations involving oil and gas projects resulted in a finding of jeopardy to listed species or destruction or adverse modification of critical habitat. In two of the consultations, FWS determined that the project may result in the taking of listed species and issued an incidental take statement, outlining reasonable and prudent measures to minimize take. The BOs for these and other projects also included details of various conservation measures which the project proponent had agreed to implement to reduce impacts to listed species. Agency staff we interviewed reported that such measures are usually proposed by BLM and/or the project proponent.

\section{KEY FINDINGS}

\section{OIL AND GAS PROJECTS}

- Total consultations - 143

○ Formal consultations -24

- Informal consultations - 119

- Traditional formal consultations - 3

- Expedited formal consultations - 21

- RIP (Upper Colorado River Basin) - 20

○ PRRIP (Platte River Basin) - 1 


\section{OIL AND GAS PROJECTS CONSULTATION DURATION}

- Consultations completed on time - 116

- Formal consultations - 22

○ Informal consultations -94

- Average consultation duration - 33 days

○ Formal consultations - 60 days

- Informal consultations - 27 days

- Average duration of traditional (nonprogrammatic) formal consultations 280 days

- Average duration of expedited (programmatic) formal consultations 28 days
Most consultations relating to oil and gas projects were completed quickly. The average duration of formal consultations was just sixty days. This does not, however, include time spent in pre-consultation discussions. Agency staff and industry representatives we interviewed reported that there are often discussions between FWS, BLM, and/or the project proponent prior to the start of consultation. These discussions can last several months and may, therefore, dramatically increase the total length of consultation. This is a concern for industry, with representatives we spoke to noting the potential for project delays. Some also emphasized the lack of predictability regarding the length of

individual consultations, while others reported inconsistencies in the process between different FWS offices and/or staff.

These issues do not arise, to the same extent, where a project is covered by a programmatic consultation. Although such projects are subject to review on an individual basis, the reviewer can rely on data and analysis from the PBO. This should reduce the potential for inconsistent review and enable the process to be completed more quickly. That has proven to be the case for oil and gas projects. Our research indicates that twenty-one projects underwent streamlined review between FY2010 and FY2014. Formal consultation on those projects lasted just twentyeight days on average, compared to an average of 280 days, for the three projects which underwent the traditional formal consultation process.

\section{(A) Formal Consultations}

Twenty-four formal consultations were undertaken with respect to oil and gas projects on BLM acreage between FY2010 and FY2014. In addition to these projects, there were likely also numerous other activities which affected listed species, but were not subject to individual consultation. As discussed in section (II)(B) above, FWS may combine multiple similar projects into a single programmatic consultation, and issue a $\mathrm{PBO}$ therefor. Where a project will not have any impacts beyond those analyzed in the PBO, FWS may conclude that it is not necessary to prepare a separate $\mathrm{BO}$, and instead simply append the project to the $\mathrm{PBO}$.

34 | Protecting Species or Endangering Development | August 2016 
Case Study 2: Programmatic Consultation on Small Oil and Gas Projects in Southern California

- Proposed Action: BLM authorization of small-scale projects (affecting less than 10 acres of habitat or linear actions less than ten miles in length) involving oil and gas development in Kings and Kern Counties in California

- Species Affected:

- 5 plants: Bakersfield cactus (Opuntia basilaris), California jewelflower (Caulanthus californicus), Hoover's wooly-star (Eriastrum hoover), Kern mallow (Eremalche kernensis), San Joaquin wooly threads (Monolopia congdonii)

- 1 reptile: blunt-nosed leopard lizard (Gambelia sila)

- 3 mammals: giant kangaroo rat (Dipodomys ingens), Tipton kangaroo rat (Dipodomys nitratoides), San Joaquin kit fox (Vulpes macrotis mutica)

- Type of Consultation: Formal. BLM sought extension of a previous PBO, issued in July 1996, covering small-scale oil and gas projects.

- Length of Consultation: 225 days (from receipt of the request for consultation $(2 / 26 / 01)$ to issuance of the BO (9/28/01)).

- Pre-Consultation Discussions: Unknown.

- FWS Determination: No jeopardy to listed species. Future oil and gas projects that meet the conditions in the PBO, or are determined to have similar effects, may be appended thereto.

- Reasons for Determination: Future projects will be required to incorporate conservation measures to minimize impacts to listed species. Project proponents will be required to, among other things, compensate for any loss of habitat by acquiring land, with the same habitat features, and transferring it to an approved entity.

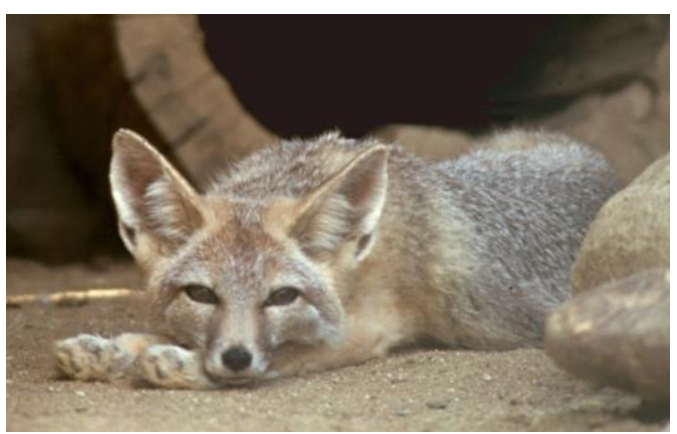

San Joaquin Kit Fox

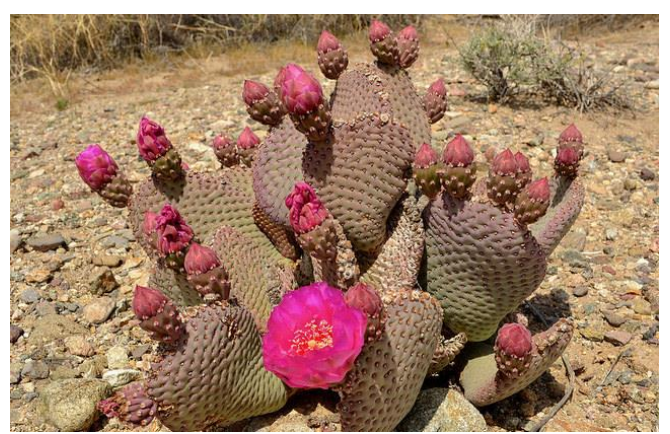

Bakersfield Cactus 
Of the twenty-four formal consultations relating to oil and gas projects, twenty-one (eighty-eight percent) proceeded in a streamlined manner, under the RIP or PRRIP, which apply to oil, gas, and other projects involving water diversions from the Upper Colorado and Platte River basins respectively. Further information on the programs is provided in section VI(B) below.

Just three (thirteen percent) of the formal consultations involving oil and gas projects underwent the standard review process. Information on these consultations is presented in Table 4below.

TABLE 4: FORMAL CONSULTATIONS UNDERTAKEN WITH RESPECT TO OIL AND GAS PROJECTS ON BLM LANDS (SHADED ROWS SIGNIFY REINITIATIONS OF CONSULTATION)

\begin{tabular}{|c|c|c|c|c|}
\hline Title & Description & Year & Species Affected ${ }^{143}$ & $\begin{array}{l}\text { Review } \\
\text { Length }\end{array}$ \\
\hline $\begin{array}{l}\text { Black Hills } \\
\text { Western Properties } \\
\text { Master } \\
\text { Development } \\
\text { Plan }^{144}\end{array}$ & $\begin{array}{l}\text { Consultation relating to a } 5 \\
\text { year program of oil and gas } \\
\text { development, involving the } \\
\text { drilling of up to } 107 \text { wells } \\
\text { in Mesa and Garfield } \\
\text { Counties in Colorado }\end{array}$ & 2010 & $\begin{array}{l}\text { Colorado hookless } \\
\text { cactus (Sclerocactus } \\
\text { glaucus), Bonytail chub } \\
\text { (Gila elegans), Colorado } \\
\text { pikeminnow } \\
\text { (Ptychocheilus lucius), } \\
\text { humpback chub (Gila } \\
\text { cypha), razorback sucker } \\
\text { (Xyrauchen texanus) }\end{array}$ & 106 days \\
\hline $\begin{array}{l}\text { Reinitiation: Oil } \\
\text { and Gas } \\
\text { Programmatic } \\
\text { Opinion }^{145}\end{array}$ & $\begin{array}{l}\text { Reinitiation of consultation } \\
\text { on BLM's Oil and Gas } \\
\text { PBO, Kern and Kings } \\
\text { Counties, California }\end{array}$ & 2012 & $\begin{array}{l}\text { Blunt-nosed leopard } \\
\text { lizard }\end{array}$ & 574 days \\
\hline $\begin{array}{l}\text { Whitewater Unit } \\
\text { Master } \\
\text { Development } \\
\text { Plan }^{146}\end{array}$ & $\begin{array}{l}\text { Consultation relating to a } 4 \\
\text { year program of oil and gas } \\
\text { development, involving the } \\
\text { drilling of up to } 108 \text { wells } \\
\text { in Mesa County in } \\
\text { Colorado }\end{array}$ & 2013 & $\begin{array}{l}\text { Colorado hookless } \\
\text { cactus, Bonytail chub, } \\
\text { Colorado pikeminnow, } \\
\text { humpback chub, } \\
\text { razorback sucker }\end{array}$ & 160 days \\
\hline
\end{tabular}


The 2012 "Oil and Gas Programmatic Opinion" was issued in response to a request, from BLM, to reinitiate formal consultation on the 2001 Oil and Gas PBO (see Case Study 2). ${ }^{147}$ The PBO analyzed the likely impact of small-scale oil and gas projects, to be undertaken in central California, in an area providing habitat for various endangered and threatened species. The PBO included an incidental take statement, specifying the permitted amount of take of four species,

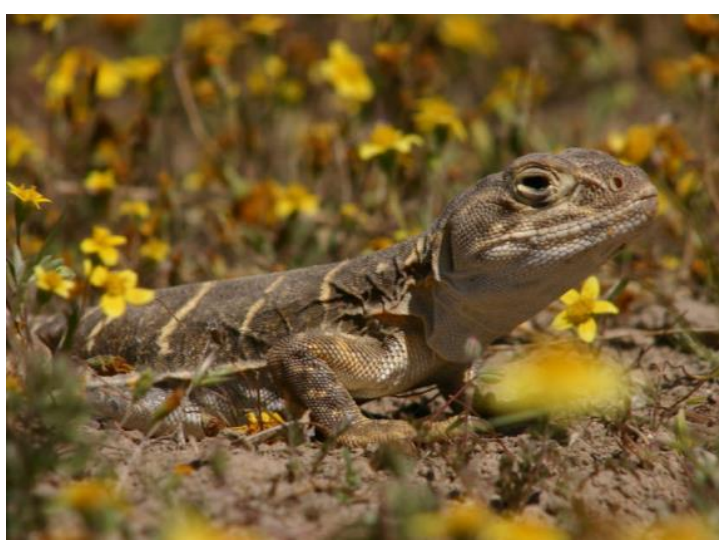

Blunt-Nosed Leopard Lizard including the blunt-nosed leopard lizard. The permitted amount was subsequently exceeded, prompting BLM to request re-initiation of consultation. In response, FWS amended the previously issued PBO, to increase the extent of authorized take. ${ }^{148}$

The other two consultations each related to a unique project involving the development, over multiple years, of oil and gas resources in Colorado. ${ }^{149}$ The two consultations lasted an average of 133 days, calculated from the date consultation was requested, until the date the BO was published. This calculation does not include the often significant amount of time devoted to preconsultation discussions and may, therefore, underestimate the total length of the consultation process.

In each consultation, FWS concluded that the project would not jeopardize the continued existence of any listed species, nor result in the adverse modification of critical habitat. This finding was based on a commitment, by the project proponent, to implement certain measures to minimize any adverse impacts on listed species and their habitat. Those measures were generally agreed between FWS, BLM, and the project proponent through pre-consultation discussions. ${ }^{150}$

Similar conservation measures were incorporated into both projects. This is perhaps unsurprising given that the projects involved the same type of activities, to be performed in the same area, and were therefore likely to have similar impacts on listed species. Indeed, FWS determined that both projects were likely to adversely affect one plant (i.e., the threatened Colorado hookless cactus) and four fish (i.e., the Bonytail chub, Colorado pikeminnow, humpback chub, razorback sucker). To minimize those effects, the project proponents agreed to:

- conduct surveys to identify listed plants in the project area;

- limit the use of vehicles and/or equipment within the project area; 
- take steps to control dust from vehicle traffic and other project activities;

- restrict the location and/or timing of project activities;

- install fencing around listed plants to avoid trampling by workers;

- minimize the spread of noxious weeds and reduce erosion and other soil changes;

- revegetate and otherwise restore the project area; and

- monitor and report on project activities.

\section{Case Study 3: Whitewater Unit Master Development Plan}

- Proposed Action: BLM approval of the Whitewater Unit Master Development Plan ("WUMDP"), proposing a four year program of oil development, including the drilling of 108 oil wells on 12 well pads, in Mesa County in Colorado.

- Species Affected:

○ 1 plant: Colorado hookless cactus

○ 4 fish: Bonytail chub, Colorado pikeminnow, Humpback chub, Razorback sucker

- Type of Consultation: Formal.

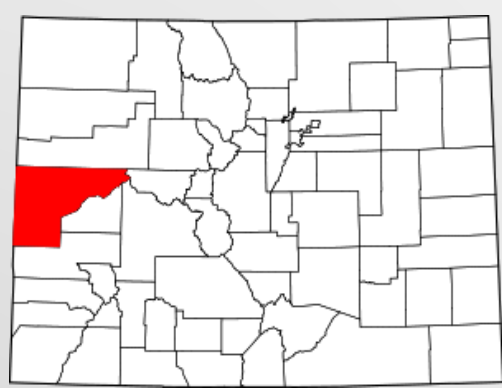

Mesa County, Colorado

- Length of Consultation: 160 days (from receipt of the request for consultation $(3 / 29 / 13)$ to issuance of the $\mathrm{BO}(9 / 2 / 13))$. Agency staff reported that the delay in issuance of the $\mathrm{BO}$ was due to a request, from the developer, that FWS prioritize review of other projects.

- Pre-consultation Discussions: $~ 1$ year. BLM first contacted FWS about the WUMDP in or around March 2012. During these initial discussions, FWS provided advice on setbacks and other measures to minimize the impact of well drilling and related activities on species.

- $\quad \boldsymbol{F W S}$ Determination: Development under the WUMDP is not likely to jeopardize listed species.

- Reasons for Determination: The developer agreed to implement various conservation measures to minimize species impacts, including restricting the timing and location of project activities, limiting the use of vehicles and equipment, controlling dust from vehicles, preventing the spread of noxious weeds, and re-vegetating the project area. 


\section{Case Study 4: Black Hills Western Properties Master Development Plan}

- Proposed Action: BLM approval of the Western Properties Master Development Plan (“WPMDP”), proposing a five-year program of oil and gas development, including the drilling of up to 107 in Garfield and Mesa Counties in Colorado.

- Species Affected:
- 1 plant: Colorado hookless cactus
○ 4 fish: Bonytail chub, Colorado pikeminnow, Humpback chub, Razorback sucker

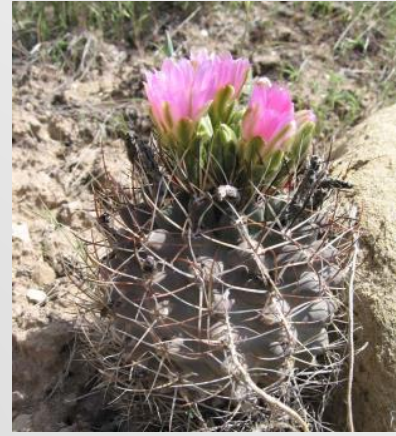

Colorado hookless cactus

- Type of Consultation: Formal

- Length of Consultation: 106 days (from receipt of the request for consultation $(4 / 1 / 10)$ to issuance of the BO $(7 / 15 / 2010)$

- Pre-Consultation Discussions: 5 months. In October 2009, FWS participated in a site visit. Following the visit, FWS was provided with information about the WPMDP and asked to comment on a draft BA, in February 2010.

- $\quad F W S$ Determination: Development under the WPMDP is not likely to jeopardize listed species.

- Reasons for Determination: No removal or direct impacts to Colorado hookless cactus are proposed. If individual cactus plants cannot be avoided by at least 100 meters, a site specific minimization plan and amended BA will be

\section{(B) Programmatic Consultations}

The bulk (eighty-eight percent) of recent formal consultations relating to oil and gas projects proceeded in a streamlined manner. Between FY2010 and FY2014, 20 oil and gas projects were subject to streamlined review under the RIP, and one under the PRRIP. In each review, FWS did not undertake a detailed assessment of the likely impacts of the project, nor identify projectspecific mitigation measures. The reviews were, therefore, generally able to be completed quickly. 


\section{STREAMLINED REVIEW OF OIL AND GAS PROJECTS IN THE UPPER COLORADO RIVER}

\section{BASIN}

Under the RIP, streamlined consultation is available for oil, gas, and other projects involving water diversions from the Upper Colorado River Basin. The basin covers approximately 69 million acres, extending from Wyoming through Utah and Colorado, into Arizona and New Mexico. ${ }^{151}$ It is home to fourteen native fish species, including:

- the Humpback Chub, a small olive colored minnow, which was listed as an endangered species in 1967;

- the Colorado Pikeminnow, a torpedo shaped green and gold minnow, listed as endangered in 1967;

- the Bonytail Chub, a medium-sized gray or olive colored minnow, listed as endangered in 1980; and

- the Razorback Sucker, a large brownish-green and yellow sucker, listed as endangered in $1991^{152}$

(together the "Endangered Colorado River Fishes").

Seeking to ensure protection of the Endangered Colorado River Fishes, on January 21, 1988, the Governors of Wyoming, Utah, and Colorado, together with the Secretary of the Interior and the Administrator of the Western Area Power Administration, entered into a cooperative agreement for the management of the Upper Colorado River Basin. ${ }^{153}$ The agreement had an initial term of fifteen years, ending in January 2003, but has been extended through September 2023. ${ }^{154}$ Under the agreement, state and federal bodies agreed to work together to implement the RIP, which aims to protect the Endangered Colorado River Fishes, including by increasing water flows in the Upper Colorado River Basin.

Absent the RIP, FWS would likely find that projects involving water depletions, including energy projects, adversely affect the Endangered Colorado River Fishes by

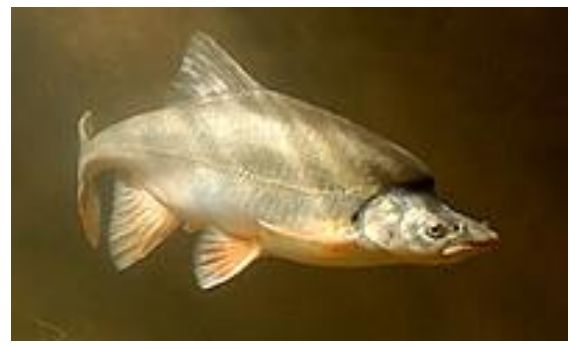

Humpback Chub

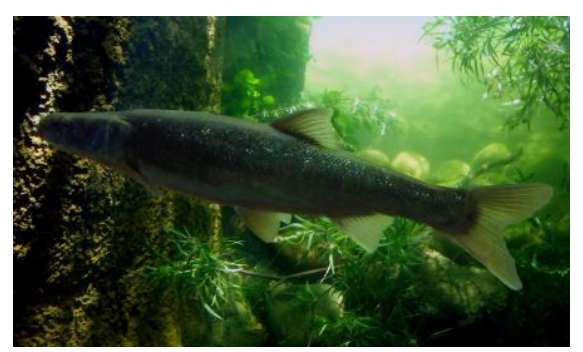

Colorado Pikeminnow

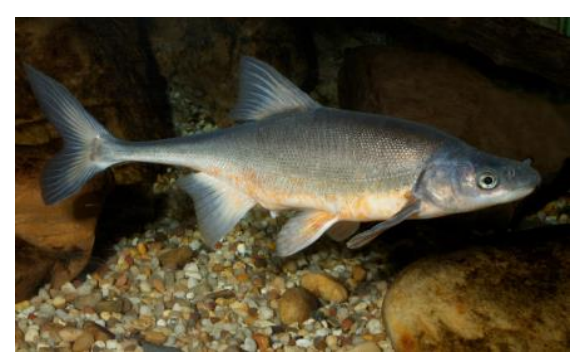

Bonytail Chub

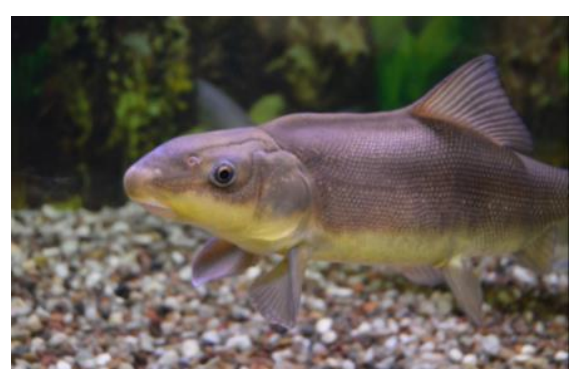

Razorback Sucker 
reducing instream flows. ${ }^{155}$ To mitigate these effects, FWS could require the project proponent to offset water depletions by returning water to the basin. ${ }^{156}$ However, because the RIP is designed to protect water flows, FWS has determined that project-specific mitigation is not necessary. Rather, the RIP may serve as the reasonable and prudent alternative to mitigate any adverse impacts to the Endangered Colorado River Fishes from new projects involving annual water depletions of up to 4,500 acre-feet. ${ }^{157}$ Where annual depletions exceed 100 acre-feet, the project proponent must pay a one-time fee of $\$ 10$ per acre-foot of water diverted, adjusted annually for inflation. ${ }^{158}$

Consistent with this framework, FWS has established a streamlined consultation process for new projects involving water depletions from the Upper Colorado River Basin. Provided sufficient progress has been made in implementing the RIP, ${ }^{159}$ FWS may undertake an expedited review, in which it identifies activities implemented under the program that may serve as the reasonable and prudent alternative to mitigate project impacts, rather than requiring project-specific mitigation measures. ${ }^{160}$

Between FY2010 and FY2014, twenty oil and gas projects were subject to streamlined review under the RIP, as the only species affected were the four endangered fish covered thereby. ${ }^{161}$ These streamlined consultations each related to projects involving the drilling of oil and/or gas wells in Wyoming and Utah. In total, there were four projects in Utah and sixteen projects in Wyoming, which together involved the drilling of 1439 wells. The projects are listed in Table 5 below.

TABLE 5: FORMAL CONSULTATIONS FOR OIL AND GAS PROJECTS UNDER THE RECOVERY IMPLEMENTATION PROGRAM FOR ENDANGERED FISH SPECIES IN THE UPPER COLORADO RIVER BASIN

\begin{tabular}{|l|l|l|l|l|}
\hline Project & Year & Water Depletions & Review Length \\
\hline Wyoming & 2010 & 0.6 acre-feet & 36 days \\
\hline Drilling of 2 wells in Sweetwater County & 2010 & 4.9 acre-feet & 29 days \\
\hline Drilling of 2 wells in Sweetwater County & 2010 & 28.7 acre-feet & 11 days \\
\hline Drilling of 7 wells in Sweetwater County & 2010 & 4.6 acre-feet & 11 days \\
\hline Drilling of 4 wells in Sweetwater County & 2010 & 10.8 acre-feet & 12 days \\
\hline Drilling of 14 wells in Sweetwater County & 2010 & 0.3 acre-feet & 48 days \\
\hline Drilling of 5 wells in Sublett \& Lincoln Counties & & &
\end{tabular}

41 | Protecting Species or Endangering Development | August 2016 


\begin{tabular}{|l|l|l|l|}
\hline Project & Year & Water Depletions & Review Length \\
\hline Drilling of 3 wells in Lincoln County & 2010 & 6.3 acre-feet & 22 days \\
\hline Drilling of 1 well in Sweetwater County & 2011 & 4.9 acre-feet & 18 days \\
\hline Drilling of 62 wells in Sweetwater County & 2011 & 65.6 acre-feet & 23 days \\
\hline Drilling of 13 wells in Sweetwater County & 2011 & 66.4 acre-feet & 65 days \\
\hline Drilling of 7 wells in Sweetwater County & 2011 & 7.3 acre-feet & 19 days \\
\hline Drilling of 13 wells in Sweetwater County & 2011 & 78.5 acre-feet & 17 days \\
\hline Drilling of 3 wells in Sweetwater County & 2011 & 5.4 acre-feet & 14 days \\
\hline Drilling of 5 wells in Sweetwater County & 2011 & 24.6 acre-feet & 26 days \\
\hline Drilling of 88 wells in Sweetwater County & 2012 & 18.4 acre-feet & 19 days \\
\hline Drilling of 483 wells in Sweetwater County & 2013 & 4.7 acre-feet & 7 days \\
\hline Utah & 2012 & 107.0 acre-feet & 52 days \\
\hline $\begin{array}{l}\text { Drilling of up to } 600 \text { wells in Uintah \& Duchesne } \\
\text { Counties }\end{array}$ & 2011 & 428.0 acre-feet & 35 days \\
\hline Drilling of 124 wells in Uintah County & 3.5 acre-feet & 97 days \\
\hline Drilling of 2 wells in Uintah County & 2014 & \\
\hline Drilling of 1 well on Ute Indian tribe land & & & \\
\hline
\end{tabular}

As shown in Table 5 above, of the twenty projects reviewed under the RIP, eighteen (ninety percent) involved annual water depletions of less than 100 acre-feet ("small depletions"). In examining these small depletions, FWS adopted a highly formulaic approach, completing only a basic project review. For each project, FWS issued a short BO, quantifying the water depletions. The BOs did not include an assessment of the likely impact of depletions on the Endangered Colorado River Fishes, nor identify project-specific mitigation measures to offset such impacts. Rather, each BO identified the RIP as the reasonable and prudent alternative to mitigate adverse project impacts. 


\section{Case Study 5: Crown Energy Partners' Drilling of 13 Natural Gas Wells}

- Proposed Action: BLM approval of APDs relating to the drilling of 13 natural gas wells in Sweetwater County in southwestern Wyoming. The driller proposed to withdraw 66.44 acre-feet of water per year from the Upper Colorado River Basin.

- Species Affected: 4 fish: bonytail chub, Colorado pikeminnow, humpback chub, and razorback sucker

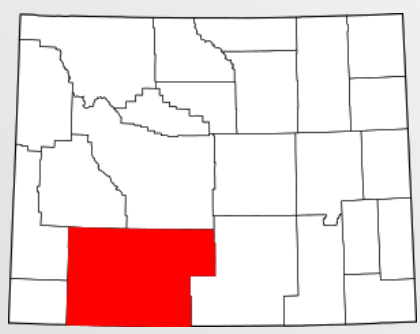

Sweetwater County

- Type of Consultation: Formal. Consultation proceeded in a streamlined manner under the RIP.

- Length of Consultation: 17 days (from receipt of the request for consultation $(7 / 5 / 11)$ to issuance of the BO $(7 / 21 / 11))$.

- Pre-consultation Discussions: None. Agency staff reported that, with the exception of projects involving very large water depletions, which may be discussed at inter-agency meetings, there are generally no pre-consultation discussions on projects covered by the RIP.

- $\quad \boldsymbol{F W S}$ Determination: The project is not likely jeopardy to listed species.

- Reasons for Determination: While water depletions associated with the project may adversely affect fish species, the RIP was intended to serve as the reasonable and prudent alternative to avoid jeopardy to species as a result of depletions.

Two of the projects reviewed under the RIP involved water depletions exceeding 100 acre-feet. Recognizing that larger depletions may have more significant impacts on the Endangered Colorado River Fish Species, FWS undertook a more detailed examination of those projects. Notably, in its BO for each project, FWS assessed the likely impact of water depletions and identified specific actions (from the RIP) that must be taken to mitigate those impacts. No such analysis was included in the BOs issued with respect to projects involving small depletions. 


\section{Case Study 6: Newfield Production's 20-acre Infield Development Project}

- Proposed Action: BLM approval of a project involving drilling of up to 600 oil wells on public lands in Uintah and Duchesne Counties in north-eastern Utah. The driller proposed to withdraw approximately 428 acre-feet of water per year from the Upper Colorado River Basin.

- Species Affected: 4 fish: bonytail chub, Colorado pikeminnow, humpback chub, and razorback sucker

○ Type of Consultation: Formal. Consultation proceeded in a streamlined manner under the RIP.

- Length of Consultation: 35 days (from receipt of the request for consultation (on 10/18/11) to issuance of the BO (on 11/21/11)).

○ Pre-consultation discussions: $~ 13$ days. Agency staff reported that there were some, informal pre-consultation discussions. There are records of email exchanges, between BLM and FWS, beginning in early October 2011.

○ $\boldsymbol{F W S}$ Determination: The project is not likely to jeopardize listed species.

- Reasons for Determination: RIP activities will serve as the conservation measures to minimize adverse effects to listed species from water depletions associated with the project. In accordance with the RIP, the project proponent will pay a one-off depletion charge of $\$ 8,221.88$. The project proponent will also implement other conservation measures, including adopting freshwater collection practices that minimize impacts on larval fish, and screening all pump intakes to prevent passage of fish into the intake.

Overall then, our analysis indicates that the RIP has expedited the review of oil and gas drilling projects involving water depletions from the Upper Colorado River Basin. On average during the period from FY2010 to FY2014, FWS's review of those projects took approximately half as long as for other similar projects, undergoing the traditional consultation process. FWS did not require, for any of the projects, adoption of site-specific mitigation measures. Rather, each project was allowed to proceed without modification.

\section{STREAMLINED REVIEW OF OIL AND GAS PROJECTS IN THE PLATTE RIVER BASIN}

FWS also provides streamlined review for certain projects, including energy projects, involving water diversions from the Platte River under the PRRIP. The PRRIP was established in 2006 to protect the land and water resources of the Platte River basin. ${ }^{162}$ One of the largest rivers in 


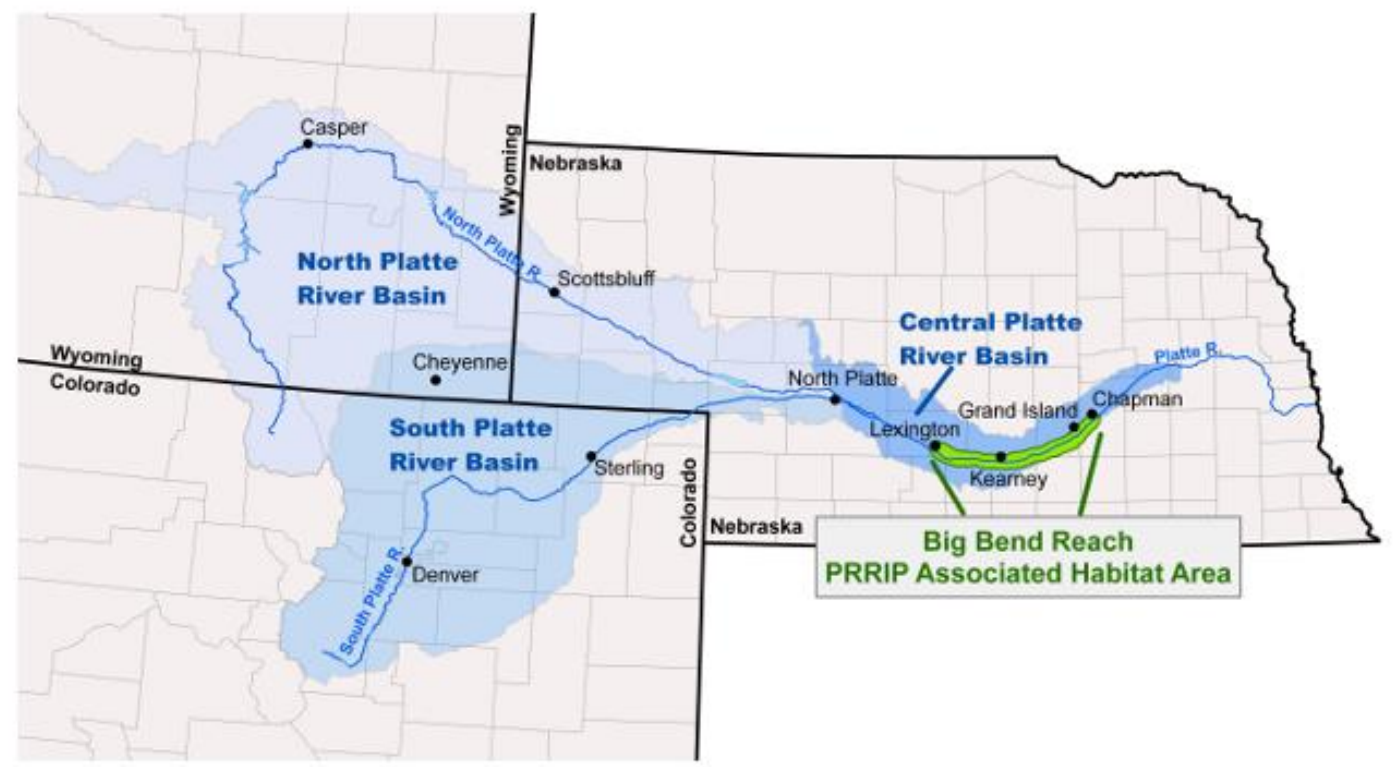

FIGURE 4: PLATTE RIVER BASIN 163

Nebraska, the Platte River is formed in the western part of the state by the confluence of the North Platte and South Platte Rivers, and flows east approximately 310 miles. The river is an important source of water for the state and is widely used in irrigation, power production, and municipal supply. It also provides vital habitat for many fish and bird species. ${ }^{164}$

The Platte River lies in the heart of the Central Flyway, one of four primary corridors used by migratory birds to travel from their nesting grounds in the north, south for the winter. During migration, birds often use the Platte River as a stopover site, to rest. Many birds also rely on the river for food, eating small fish and aquatic invertebrates, such as insects, crustaceans, and mollusks. While the Platte River was once home to numerous aquatic species, in recent years, fish numbers have declined as a result of changes in river flows.

Recognizing this, FWS has repeatedly expressed concern that projects involving water diversions from the Platte River could jeopardize the continued existence of fish and other species. Species of concern include:

- the pallid sturgeon (Scaphirbynchus albus), a light brown and white fish with a long slender body and flattened shovelshaped snout, which was listed as endangered in 1990;165

- the whooping crane (Grus Americana), a large wading bird with a white body and contrasting black wing tips, gray-

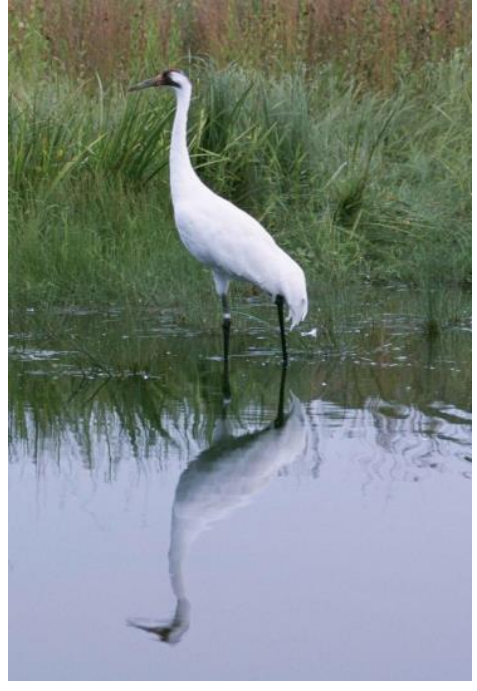

Whooping Crane 


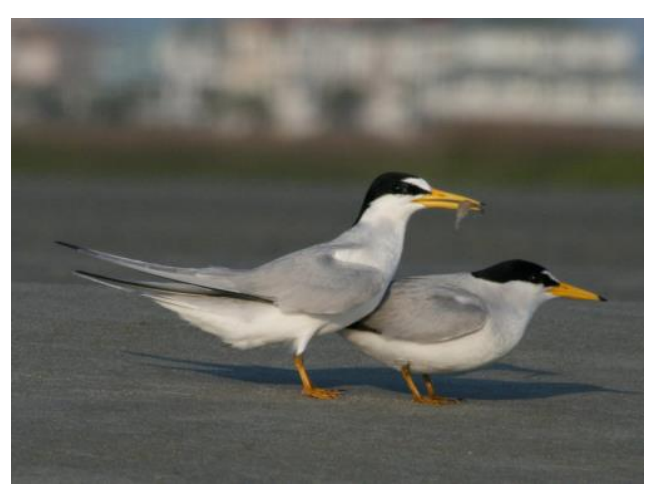

Least Tern

black legs, and a red face and crown, listed as endangered in 1967;166

- the least tern (Sterna antillarum), a small gray and white bird with black streaking on the head and orange legs, listed as endangered in $1985 ;^{167}$ and

- the piping plover (Charadrius melodus), a sandgray, robin-sized bird with dark bands across its forehead and breast, listed as threatened in $1985^{168}$ (together the "Platte River Fish and Bird Species").

Seeking to promote recovery of the Platte River Fish and Bird Species, in 2006, the Governors of Colorado, Nebraska, and Wyoming and the Secretary of the Interior entered into an agreement to implement the PRRIP. The PRRIP aims to maintain and enhance species habitat by, among other things, increasing river flows. ${ }^{169}$ The participating governments set a goal of reducing target flow shortages by an average of 130,000 to 150,000 acre-feet per year during the first thirteen years of the PRRIP. ${ }^{170}$

In June 2006, FWS issued a PBO assessing the effects of the PRRIP, and certain existing 171 and new ${ }^{172}$ water-related activities participating in the PRRIP, on endangered and threatened species (the "PRRIP PBO"). 173 Based on its assessment, FWS determined that the PRRIP "would help offset the adverse impacts to the Platte River ecosystem from the continued operation of existing and certain new water-related activities that occur in the basin upstream." 174 The PRRIP may, therefore, be relied upon to mitigate the impact of projects involving water depletions from the Platte River. Project-specific mitigation is generally not required, unless the project proponent refuses to participate in the PRRIP. Even where the project proponent does participate, however, the PRRIP will only serve to mitigate the downstream effects of river flow depletions on the Platte River Fish and Bird Species. ${ }^{175}$ To the extent that the project affects other species, those effects must be addressed separately. ${ }^{176}$

- The PRRIP is intended to satisfy any consultation requirements arising in connection with the continued operation of existing water diversions. ${ }^{177}$ It also establishes a streamlined process for consultation on new water diversions. ${ }^{178}$ The consultation process consists of two tiers as follows: Tier $1=$ Issuance of the PBO; and

- $\quad$ Tier 2 = Project-specific BOs. ${ }^{179}$

The bulk of FWS's analysis of is done under tier 1 and reported in the PBO. This analysis is then incorporated into subsequent tier 2 (project-specific) BOs. These tier 2 BOs tend, therefore, to be simple boilerplate documents which merely identify the source of water to be used in the 


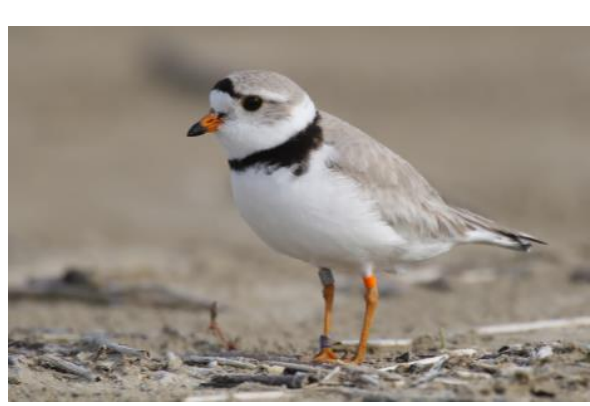

Piping Plover project and document the method of use. The BOs typically do not quantify the amount of water to be diverted, assess the impact of the diversion on species, or require adoption of project-specific conservation measures.

This two-tiered process was followed in one formal consultation, undertaken with respect to an oil and gas project on BLM land (the "Platte River Project"), between FY2010 and FY2014. The Platte River Project involved the drilling of four oil and gas wells, requiring the use of approximately 18.2 acre feet of water, proposed to be withdrawn from the North Platte River. ${ }^{180}$ FWS issued a tier 2 BO in respect of the Platte River Project. The BO identified the amount and source of water to be used in the project, but did not analyze the effects of such use on the Platte River Fish and Bird species. Rather, it merely incorporated the effects analysis from the PRRIP PBO. FWS was therefore able to complete its review quickly, taking just fifteen days to issue its BO, after receiving the request for consultation. 


\section{Case Study 7: Three Forks Resources' Oil Well Development in central} Wyoming

- Proposed Action: BLM approval of APDs relating to the drilling of 4 oil and gas wells in Natrona County in Wyoming. The driller proposed to withdraw approximately 18.2 acre-feet of water over 2 years from the Platte River basin.

- Species Affected:

○ 1 fish: pallid sturgeon

○ 3 birds: least tern, piping plover, whooping crane

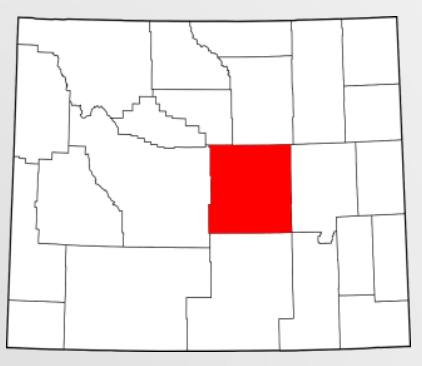

Natrona County, Wyoming

- Type of Consultation: Formal. Consultation proceeded in a streamlined manner under the PRRIP. The BO was tiered to the PRRIP PBO.

- Length of Consultation: 15 days (from receipt of the request for consultation $(6 / 5 / 2014)$ to issuance of the BO $(6 / 19 / 14))$

- Pre-consultation Discussions: None. Agency staff reported that, with the exception of projects involving large water depletions, which may be discussed at interagency team meetings, there are generally no pre-consultation discussions on projects covered by the PRRIP.

- $\quad \boldsymbol{F W S}$ Determination: The project is not likely to jeopardize listed species.

- Reasons for Determination: The PRRIP serves to mitigate any impacts on listed species from water withdrawals associated with the project 


\section{(C) Informal Consultations}

The majority (eighty-three percent) of recent consultations involving oil and gas development were conducted on an informal basis. Between FY2010 and FY2014, 119 informal consultations were undertaken with respect to oil and gas development, almost five times the number of formal consultations. As discussed in section II(A) above, informal consultation may be undertaken where BLM is of the view that development "may affect, but is not likely to adversely affect" listed species. Provided FWS concurs with that view, consultation may be terminated without further action, including preparation of a BO. FWS aims to complete informal consultation and issue a concurrence letter within thirty days. ${ }^{181}$

Of the 119 informal consultations relating to oil and gas development, ninety-four (seventy-nine percent) were completed within the target of thirty days. Of the remaining twenty-five consultations, the majority were completed within sixty days, though some lasted in excess of 120 days. The average length of review, across all 119 consultations, was twenty-seven days. This does not, however, include time spent on pre-consultation discussions. Based on interviews with agency staff, we understand that the extent of pre-consultation discussions varies depending on the nature of the project and the field office handling consultation, among other factors. In most cases, prior to filing a consultation request, BLM staff will notify FWS about a project and request a species list and/or other relevant information.

\section{Case Study 8: PetroQuest Energy's Oil Drilling in North Eastern Oklahoma}

- Proposed Action: BLM approval of the drilling of two oil wells in Pawnee County in Oklahoma

- Species Affected: American burying beetle (Nicrophorus americanus)

- Type of Consultation: Informal

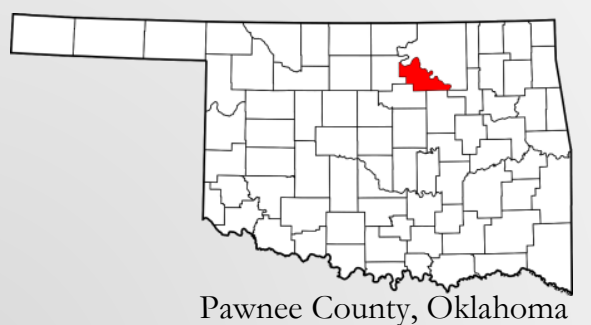

Pawnee County, Oklahoma

- Length of Consultation: 35 days. BLM used the online project review process developed by FWS's Oklahoma Field Office for projects that are not likely to adversely affect listed species. Under that process, an action agency may submit information on a project to FWS and, if FWS does not respond within thirty-five days, consultation may be considered complete.

- Pre-Consultation Discussions: Minimal. BLM staff obtained a species list from FWS on October 9, 2012. There were no other pre-consultation discussions between the two agencies.

- $\quad \boldsymbol{F W S}$ Determination: The project is not likely to adversely affect listed species. 


\section{Solar Energy Project Consultations}

The BLM manages over 19 million acres of public lands with solar energy potential in six states - California, Nevada, Arizona, New Mexico, Colorado and Utah. ${ }^{182}$ Solar energy development on public lands has accelerated rapidly in recent years. BLM had not permitted any solar energy projects on public lands prior to 2009. However, as a result of both federal and state incentives, BLM approved approximately twenty-nine utilityscale solar energy projects between FY2010

\section{KEY FINDINGS - SOLAR ENERGY}

- Total consultations -27

- Formal consultations - 19

- Informal consultations - 8

- Average consultation duration - 131 days

- Formal consultations -176 days

- Informal consultations - 66 days and FY2014, including some "connected action" projects on private lands that required BLM approvals for off-site facilities, such as transmission lines or access. ${ }^{183}$ Connected action projects were not analyzed in this study.

Based on FWS's TAILS records and data obtained from BLM, we estimate that twenty-seven consultations were undertaken with respect to solar energy projects between FW2010 and FY2014. The majority (seventy percent) of those consultations proceeded on a formal basis.

BLM records indicate that twenty-nine solar energy projects were permitted from FY2010 to FY2014. ${ }^{184}$ This includes two projects which were undertaken on tribal lands and ten connected action projects occurred on private lands. Those projects were excluded from our study. Of the remaining seventeen projects, all but three were subject to consultation under the ESA. Fourteen projects (eighty-two percent of the total) underwent consultation. For some of the projects, BLM had to re-initiate consultation as a result of project modifications. Additionally, two projects were consolidated into one consultation.

\section{(A) Formal Consultations}

Between the end of 2009 through 2014, FWS engaged in seventeen traditional (not programmatic) formal consultations for fourteen utility-scale solar projects. The consultations are listed in Table 6. 
TABLE 6: FORMAL CONSULTATIONS INVOLVING SOLAR ENERGY DEVELOPMENT ON BLM LANDS (SHADED ROWS SIGNIFY REINITIATIONS OF CONSULTATION)

\begin{tabular}{|c|c|c|c|c|c|}
\hline Title & Description & Year & $\begin{array}{l}\text { Species } \\
\text { Affected }^{185}\end{array}$ & $\begin{array}{l}\text { Review } \\
\text { Length }\end{array}$ & Status \\
\hline $\begin{array}{l}\text { Lucerne Valley } \\
\text { Chevron Solar } \\
\text { Project }\end{array}$ & $\begin{array}{l}\text { Consultation on a } 45 \\
\text { MW solar PV power } \\
\text { plant on } 516 \text { acres in San } \\
\text { Bernardino County, } \\
\text { California }\end{array}$ & 2009 & $\begin{array}{l}\text { Mojave desert } \\
\text { tortoise (Gpherus } \\
\text { agassizii) }\end{array}$ & 183 days & $\begin{array}{l}\text { Project } \\
\text { terminated by } \\
\text { developer }\end{array}$ \\
\hline $\begin{array}{l}\text { Re-initiation: } \\
\text { Lucerne Valley } \\
\text { Chevron Solar } \\
\text { Project }\end{array}$ & $\begin{array}{l}\text { Re-initiation of formal } \\
\text { consultation due to } \\
\text { removal of compensation } \\
\text { measures in the original } \\
\text { BO }\end{array}$ & 2010 & $\begin{array}{l}\text { Mojave desert } \\
\text { tortoise }\end{array}$ & 3 days & $\begin{array}{l}\text { Project } \\
\text { terminated by } \\
\text { developer }\end{array}$ \\
\hline $\begin{array}{l}\text { Imperial Valley } \\
\text { Solar Project }\end{array}$ & $\begin{array}{l}\text { Consultation on a } 709 \\
\text { MW solar dish stirling } \\
\text { engine project on } 6,571 \\
\text { acres in Imperial County, } \\
\text { California }\end{array}$ & 2009 & $\begin{array}{l}\text { Peninsular big } \\
\text { horn sheep (Ovis } \\
\text { Canadensis } \\
\text { nelson); flat-tailed } \\
\text { horned lizard } \\
\text { (Phrynosoma } \\
\text { mcallii) }\end{array}$ & 270 days & $\begin{array}{l}\text { Project } \\
\text { terminated by } \\
\text { developer }\end{array}$ \\
\hline $\begin{array}{l}\text { Ivanpah Solar } \\
\text { Electric } \\
\text { Generating } \\
\text { System }\end{array}$ & $\begin{array}{l}\text { Consultation on a } 370 \\
\text { MW solar thermal power } \\
\text { plant on } 3,582 \text { acres in } \\
\text { San Bernardino County, } \\
\text { California }\end{array}$ & 2009 & $\begin{array}{l}\text { Mojave desert } \\
\text { tortoise }\end{array}$ & 299 days & $\begin{array}{l}\text { Operations } \\
\text { began in } \\
\text { December } \\
2013\end{array}$ \\
\hline $\begin{array}{l}\text { Re-initiation: } \\
\text { Ivanpah Solar } \\
\text { Electric } \\
\text { Generating } \\
\text { System }\end{array}$ & $\begin{array}{l}\text { Re-initiation of formal } \\
\text { consultation due to } \\
\text { discovery of additional } \\
\text { desert tortoises. }\end{array}$ & 2011 & $\begin{array}{l}\text { Mojave desert } \\
\text { tortoise }\end{array}$ & 103 days & $\begin{array}{l}\text { Operations } \\
\text { began in } \\
\text { December } \\
2013\end{array}$ \\
\hline
\end{tabular}




\begin{tabular}{|c|c|c|c|c|c|}
\hline Title & Description & Year & $\begin{array}{l}\text { Species } \\
\text { Affected }^{185}\end{array}$ & $\begin{array}{l}\text { Review } \\
\text { Length }\end{array}$ & Status \\
\hline $\begin{array}{l}\text { Silver State } \\
\text { (North) Solar } \\
\text { Energy Project }\end{array}$ & $\begin{array}{l}\text { Consultation on Phase I } \\
\text { of the Silver State } \\
\text { project, involving } \\
\text { construction of a } 60 \mathrm{MW} \\
\text { solar PV plant in Clark } \\
\text { County, Nevada }\end{array}$ & 2010 & $\begin{array}{l}\text { Mojave desert } \\
\text { tortoise }\end{array}$ & 206 days & $\begin{array}{l}\text { Operations } \\
\text { began in May } \\
2012\end{array}$ \\
\hline $\begin{array}{l}\text { Re-initiation: } \\
\text { Silver State } \\
\text { (North) Solar } \\
\text { Energy Project }\end{array}$ & $\begin{array}{l}\text { Reinitiation of formal } \\
\text { consultation to include } \\
\text { geothermal testing within } \\
\text { desert tortoise habitat }\end{array}$ & 2010 & $\begin{array}{l}\text { Mojave desert } \\
\text { tortoise }\end{array}$ & 10 days & $\begin{array}{l}\text { Operations } \\
\text { began in May } \\
2012\end{array}$ \\
\hline $\begin{array}{l}\text { Calico Solar } \\
\text { Energy Project }\end{array}$ & $\begin{array}{l}\text { Consultation on a } 4,613- \\
\text { acre solar power } \\
\text { generating facility and the } \\
\text { establishment of a 3,617- } \\
\text { acre solar development } \\
\text { exclusion zone }\end{array}$ & 2010 & $\begin{array}{l}\text { Mojave desert } \\
\text { tortoise }\end{array}$ & 192 days & $\begin{array}{l}\text { Project } \\
\text { terminated by } \\
\text { developer }\end{array}$ \\
\hline $\begin{array}{l}\text { Amargosa } \\
\text { Farm Road } \\
\text { Solar Project }\end{array}$ & $\begin{array}{l}\text { Consultation on a } 232- \\
\text { MW parabolic trough, } \\
\text { dry-cooled solar power } \\
\text { plant on } 4,340 \text { acres in } \\
\text { Nye County, Nevada }\end{array}$ & 2010 & $\begin{array}{l}\text { Mojave desert } \\
\text { tortoise }\end{array}$ & 165 days & $\begin{array}{l}\text { Project } \\
\text { terminated by } \\
\text { developer }\end{array}$ \\
\hline $\begin{array}{l}\text { Blythe Solar } \\
\text { Power Project }\end{array}$ & $\begin{array}{l}\text { Consultation on a } 1,000 \\
\text { MW parabolic trough } \\
\text { solar facility in Riverside } \\
\text { County, California }\end{array}$ & 2010 & $\begin{array}{l}\text { Mojave desert } \\
\text { tortoise }\end{array}$ & 74 days & $\begin{array}{l}\text { Operations to } \\
\text { begin in } 2016\end{array}$ \\
\hline
\end{tabular}




\begin{tabular}{|c|c|c|c|c|c|}
\hline Title & Description & Year & $\begin{array}{l}\text { Species } \\
\text { Affected }^{185}\end{array}$ & $\begin{array}{l}\text { Review } \\
\text { Length }\end{array}$ & Status \\
\hline $\begin{array}{l}\text { Re-initiation: } \\
\text { Blythe Solar } \\
\text { Power Project }\end{array}$ & $\begin{array}{l}\text { Re-initiation of } \\
\text { consultation due to } \\
\text { proposal to convert to } \\
\text { PV technology. Project } \\
\text { foot print reduced from } \\
7,027 \text { acres to } 4,070 \text { acres } \\
\text { and from } 1,000 \mathrm{MW} \text { to } \\
485 \mathrm{MW} \text {. }\end{array}$ & 2014 & $\begin{array}{l}\text { Mojave desert } \\
\text { tortoise }\end{array}$ & 240 days & $\begin{array}{l}\text { Operations to } \\
\text { begin in } 2016\end{array}$ \\
\hline $\begin{array}{l}\text { Genesis Solar } \\
\text { Energy Project }\end{array}$ & $\begin{array}{l}\text { Consultation on a } 250 \\
\text { MW parabolic trough } \\
\text { solar facility on } 4,640 \\
\text { acres in Riverside } \\
\text { County, California }\end{array}$ & 2010 & $\begin{array}{l}\text { Mojave desert } \\
\text { tortoise }\end{array}$ & 119 days & $\begin{array}{l}\text { Operations } \\
\text { began in } \\
\text { November } \\
2013\end{array}$ \\
\hline $\begin{array}{l}\text { Desert } \\
\text { Sunlight Solar } \\
\text { Farm }\end{array}$ & $\begin{array}{l}\text { Consultation on a } 550 \\
\text { MW thin film PV solar } \\
\text { facility on } 4,165 \text { acres in } \\
\text { Riverside County, } \\
\text { California }\end{array}$ & 2010 & $\begin{array}{l}\text { Mojave desert } \\
\text { tortoise }\end{array}$ & 230 days & $\begin{array}{l}\text { Operations } \\
\text { began in } 2014\end{array}$ \\
\hline $\begin{array}{l}\text { Palen Solar } \\
\text { Power Project }\end{array}$ & $\begin{array}{l}\text { Consultation on a } 500 \\
\text { MW parabolic trough } \\
\text { solar facility on } 3,800 \\
\text { acres in Riverside } \\
\text { County, California }\end{array}$ & 2011 & $\begin{array}{l}\text { Mojave desert } \\
\text { tortoise }\end{array}$ & 143 days & $\begin{array}{l}\text { Operations to } \\
\text { begin in } 2016\end{array}$ \\
\hline $\begin{array}{l}\text { McCoy Solar } \\
\text { Project }\end{array}$ & $\begin{array}{l}\text { Consultation on a } 750 \\
\text { MW PV solar facility on } \\
7,700 \text { acres in Riverside } \\
\text { County, California }\end{array}$ & 2012 & $\begin{array}{l}\text { Mojave desert } \\
\text { tortoise }\end{array}$ & 354 days & $\begin{array}{l}\text { Under } \\
\text { construction }\end{array}$ \\
\hline
\end{tabular}




\begin{tabular}{|c|c|c|c|c|c|}
\hline Title & Description & Year & $\begin{array}{l}\text { Species } \\
\text { Affected }^{185}\end{array}$ & $\begin{array}{l}\text { Review } \\
\text { Length }\end{array}$ & Status \\
\hline $\begin{array}{l}\text { Desert Harvest } \\
\text { Solar Project }\end{array}$ & $\begin{array}{l}\text { Consultation on a } 150 \\
\text { MW solar PV plant on } \\
1,208 \text { acres in Riverside } \\
\text { County, California }\end{array}$ & 2012 & $\begin{array}{l}\text { Mojave desert } \\
\text { tortoise }\end{array}$ & 251 days & $\begin{array}{l}\text { Construction } \\
\text { has not } \\
\text { begun. }\end{array}$ \\
\hline $\begin{array}{l}\text { Stateline Solar } \\
\text { and Silver State } \\
\text { Solar South } \\
\text { Projects }\end{array}$ & $\begin{array}{l}\text { Consultation on two } \\
\text { projects: (1) the Stateline } \\
\text { project which is a } \\
\text { proposed } 300 \text { MW solar } \\
\text { PV plant on 1,685 acres } \\
\text { in San Bernardino } \\
\text { County, California and } \\
\text { (2) the Silver State South } \\
\text { Solar project which is } 250 \\
\text { MW plant on 2,400 acres } \\
\text { in Clark County, Nevada }\end{array}$ & 2013 & $\begin{array}{l}\text { Mojave desert } \\
\text { tortoise }\end{array}$ & 272 days & $\begin{array}{l}\text { Operations to } \\
\text { begin in } 2016\end{array}$ \\
\hline
\end{tabular}

For some of these projects, FWS engaged in multiple consultations with BLM, as changes to the project required re-initiation of consultation. All but one of the consultations involved impacts to the Mojave desert tortoise, and all of the consultations were traditional, stand-alone consultations.

From discussions with agency staff, we understand that project applicants, BLM, and FWS make every effort to begin discussions regarding the project as early as possible. Preapplication meetings with BLM often occur as soon as the project developer has the initial idea. Sometimes FWS is engaged at this very early stage, other times it is after BLM has a better idea of the site location and what resources will be impacted. Often, FWS receives a request from the applicant for information on endangered and threatened species near

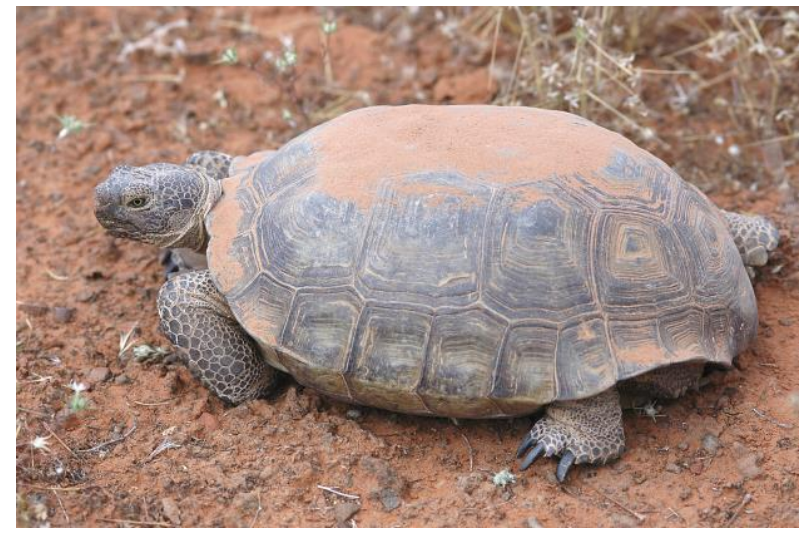

Mojave Desert Tortoise 
the proposed project site, and this initiates what FWS refers to as early "informal" consultation or early coordination. It is important to note that this type of early "informal" consultation is not the informal consultation process under section 7 of the ESA. It is simply staff's way of describing the early meetings and discussions that take place prior to initiation of consultation.

The NEPA process and the ESA section 7 consultation process almost always occur simultaneously. BLM staff explained that often the BA that BLM sends to FWS with its request for formal consultation is completed around the same time as BLM completes the draft EIS under NEPA. The BO is often based on the draft EIS. One industry representative explained that FWS will refine the conservation measures developed in the draft EIS and BA and incorporate these into the $\mathrm{BO}$.

Since all but one of the BOs FWS issued between FY2010 and FY2014 with respect to utilityscale solar projects involved the desert tortoise, in general, the conservation measures are all similar. From discussions with agency representatives, we understand that the development of conservation measures is often a collaborative process, with FWS, BLM and the applicant working together to develop them. Conservation measures often include requirements to:

- perform pre-construction species surveys;

- develop a tortoise translocation plan;

- install fencing to exclude tortoises from the project area;

- implement litter control;

- develop a weed management and a raven management plan; and

- appoint a biologist to ensure compliance with conservation measures.

In all of the solar project consultations, FWS determined that the proposed project was not likely to jeopardize the continued existence of the desert tortoise (or the Peninsular bighorn sheep and flat-tailed horned lizard in the case of the Imperial Valley Solar Project). FWS issued incidental take statements authorizing a certain number of takes of desert tortoises, provided that BLM and the applicant comply with the conservations measures set forth in the BO.

Most of the solar project consultations listed in Table 6 were not completed within the 135 day time limit in the ESA. FWS staff indicated they were pushed by industry to meet this time limit throughout the process. However, the reality is these early solar projects were the first of their kind on public lands, with huge footprints in extremely sensitive desert ecosystems. It was often difficult for FWS to complete its review within 135 days for projects as large as these first utilityscale solar plants.

55 | Protecting Species or Endangering Development | August 2016 


\section{Case Study 9: Ivanpah Solar Electric Generating System in Southern}

\section{California}

- Proposed Action: BLM grant of a ROW for construction of a 370 MW thermal solar energy project in San Bernardino County in California.

- Species Affected: Mojave desert tortoise

- Type of Consultation: Formal (reinitiation). The project was subject to consultation in 2009 to 2010. Consultation was reinitiated in February 2011 because, following the commencement of construction activities, BLM discovered that more desert tortoise were present in the project area than originally believed.

- Length of Consultation: 103 days (from receipt of the request for reinitiation of consultation $(2 / 28 / 11)$ to issuance of the $\mathrm{BO}(6 / 10 / 11))$.

- Pre-Consultation Discussions: FWS began participating during NEPA scoping as early as 2007.

- $\quad \boldsymbol{F W S}$ Determination: The project is not likely to jeopardize listed species.

- Reasons for Determination: In general, project activities were likely to kill few desert tortoises of reproductive age due to implementation of minimization measures, such as fencing, tortoise relocation, and monitoring; applicant agreed to implement measures to reduce potential for increased predation and spread of non-native plant species. 


\section{Case Study 10: Stateline Solar and Silver State South Projects in California}

- Proposed Action: BLM grant of ROWs for construction of two solar energy projects: (1) the Stateline Solar Project, involving construction of a 300 MW PV plant in San Bernardino County in California, and (2) the Silver State South Project, involving construction of a 250 MW plant in Clark County in Nevada.

- Species Affected: Mojave desert tortoise

- Type of Consultation: Formal. In January 2013, BLM requested consultation on the Stateline Project. In February 2013, BLM requested reinitiation of consultation on the Silver State Project, in respect of which FWS had issued a BO in September 2010. Subsequently, in March 2013, FWS requested that BLM consolidate the two requests, due to the close proximity of the projects, the similarity between their effects, the fact that the same parent company proposed both projects, and the need to comprehensively address impacts to habitat and connectivity.

- Length of Consultation: 272 days (from the date of consolidation of the consultation requests to issuance of the $\mathrm{BO}(9 / 30 / 13)$.

- Pre-Consultation Discussions: Agreement to consolidate on 3/12/13, thereafter BLM and FWS engaged in discussions regarding both project layouts to reduce the effects of the proposed actions on the tortoise and a means of monitoring project impacts. BLM issued BA's for both projects in July 2013.

- $\quad \boldsymbol{F W S}$ Determination: The projects are not likely to jeopardize listed species.

- Reasons for Determination: Applicant reduced overall acreage of the Stateline facility and shifted entire project to the east. Applicant also moved phase II of the Silver State project to the west and removed phase III from the project, thereby reducing impacts to tortoise habitat. 


\section{(B) Programmatic Consultations}

As described in Section III above, in 2012, BLM established the Solar Energy Program. The Program applies in six western states and, in each of those states, designates SEZs where solar energy projects are to be prioritized. When a project is proposed within a SEZ, consultation operates under a tiered, two staged approach. The first stage - the Solar PBO - evaluates landscape level effects. The second stage is project specific, examining specific effects of the individual project. The goal is to develop landscape level conservation measures upfront to provide BLM and project applicants with some degree of certainty. To date, FWS has issued three BOs tiered to the Solar PBO for three solar projects proposed to be built in the Dry Lake SEZ in Nevada (discussed in Case Study 11 below).

Interestingly, although the projects in the Dry Lake SEZ are the first tiered to the Solar PBO, they are not the first projects to be built in a SEZ. For example, the McCoy Solar Power Project is located in the Riverside SEZ in California. FWS issued the project specific BO on March 2013. It was not tiered to the Solar PBO. In fact, according to agency representatives, none of the project-specific BOs for projects within the Riverside SEZ have been tiered to the Solar PBO. The agency representatives we spoke to indicated that this is because applications with respect to the projects were filed before finalization of the Solar PBO. The project applications were grandfathered and therefore not subject to the PBO. 
Case Study 11: Project-level Formal Consultation on Four Solar Energy

Projects in the Dry Lake Solar Energy Zone

- Proposed Action: Grant of ROWs, by BLM, relating to 4 solar energy projects in the Dry Lake SEZ in Clark County in Nevada.

- Species Affected: Mojave desert tortoise. 1 of the 4 projects also affected the Moapa dace (Moapa coriacea)

- Type of Consultation: Formal. 3 of the 4 formal consultations were tiered to the Solar PBO. The 4th project did not meet the minimum size requirement for a SEZ project and therefore was not tiered to the Solar PBO.

- Length of Consultation: 94 days

- Pre-consultation Discussions: Unknown

- FWS Determination: The projects are not likely to jeopardize listed species

- Reasons for Determination: The project proponents agreed to implement various conservation measures. Many of these measures are based on measures in the Solar PBO. There were also some additional measures, not included in the Solar PBO.

As discussed in Section III above, one goal of establishing Solar Energy Zones is to reduce the overall permitting time. A recent study by the Wilderness Society indicates that the average permitting time for projects inside a SEZ is reduced by over fifty percent when compared with projects outside solar energy zones. ${ }^{186}$ For the four projects permitted in the Dry Lake SEZ, the study concluded that the permitting time lasted on average 9.7 months, as opposed to over twenty months on average for projects outside of a SEZ. ${ }^{187}$ Additionally, the consultation time for projects within a SEZ is reduced, as these projects are tiered to a programmatic biological opinion. For example, the consultation time for the four projects in the Dry Lake SEZ was 94 days, whereas consultations for standalone solar projects often exceeded the statutory deadline of 135 days.

\section{(C) Informal Consultations}

As noted above, the majority of consultations related to utility-scale solar energy projects proceeded on a formal basis. Between FY 2010 and FY 2014, BLM and FWS engaged in only eight informal consultations as opposed to nineteen formal consultations. The reason for the higher number of formal consultations is that the majority of utility-scale solar projects affected 
large areas of Mojave desert tortoise habitat and were therefore considered likely to adversely affect tortoise populations. This finding necessitated formal consultation under the ESA.

A few of the informal consultations related to FWS's determination that a project may affect but was not likely to adversely affect a particular species. For example, FWS concurred with BLM's conclusion that the Centinela Solar Energy Project and the Camp Verde Solar Project in Imperial County, California would not adversely affect the southwestern willow flycatcher or the Yuma clapper rail, as a result of specific measures the applicant agreed to incorporate into the project, such as preventing loss of riparian and wetland vegetation, and minimizing disturbances from construction during flycatcher migration seasons. ${ }^{188}$ Other informal consultations involved FWS's concurrence that additional activities related to a particular project, which had already gone through formal consultation, would be covered under the existing BO. ${ }^{189}$ Finally, for one informal consultation related to the Imperial Valley Solar Project, FWS issued a non-concurrence letter to BLM determining that the project may affect the peninsular bighorn sheep and initiation of formal consultation would be required. ${ }^{190}$ 


\section{Wind Energy Project Consultations}

Only a small portion of recent section 7 consultations relating to energy projects on BLM lands involved wind energy development. Of the 179 consultations undertaken between FY2010 and FY2014, just nine (five percent) involved wind energy development. Of those consultations, six proceeded on a formal basis, and three on an informal basis. Agency staff interviewed for this study reported that the high rate of formal consultation reflects the fact that most wind energy developments pose significant risks to birds, bats, and/or other listed species, because of where they are located and their size.

\section{KEY FINDINGS - WIND ENERGY}

- Total consultations - 9

- Formal consultations -6

- Informal consultations - 3

- Consultations completed on time - 3

○ Formal consultations - 2

- Informal consultations - 1

- Average consultation duration - 144 days

○ Formal consultations -172 days

○ Informal consultations -88 days

- Expedited formal consultations - 1

After reviewing the BOs issued by FWS in the formal consultations, we determined that each consultation related to a unique project:

- five projects involved development of new wind energy facilities on public lands; and

- one project involved operation and maintenance switchyards to support existing wind energy facilities.

Focusing on new developments, BLM's records indicate that ten wind energy projects were permitted on public lands from FY2010 to FY2014. ${ }^{191}$ This includes three "connected action" projects that occurred on private lands but required BLM approval for off-site facilities. ${ }^{192}$ Those projects have, therefore, been excluded from this study. Of the remaining seven projects which occurred on public lands, all but two (seventy-one percent) were subject to formal consultation under the ESA.

In each formal consultation, FWS found that wind energy development would not jeopardize the continued existence of listed species or destroy or adversely modify critical habitat, provided the developer implemented certain conservation measures. We understand from agency staff that such measures are generally proposed by the developer and/or BLM and discussed with FWS prior to and/or during consultation.

61 | Protecting Species or Endangering Development | August 2016 
The average length of the formal consultations relating to wind energy development was 172 days, calculated from the initiation of consultation to the publication of a $\mathrm{BO}$, and excluding time spent on pre-consultation discussions. According to agency staff interviewed for this study, in most cases, the delay in publishing a BO was likely due to staffing constraints. In just two consultations were the BOs published within the maximum (135 day) time limit set in the ESA. The shortest consultation lasted nine days, with FWS taking advantage of the streamlined review process, established in the RIP and PRRIP.

\section{(A) Formal Consultations}

Between FY2010 and FY2014, six formal consultations were undertaken with respect to wind energy projects on BLM lands. Details of each consultation are provided in Table 7 below.

TABLE 7: FORMAL CONSULTATIONS INVOLVING WIND ENERGY DEVELOPMENT ON BLM LANDS

\begin{tabular}{|l|l|l|l|l|l|}
\hline Title & Description & Year & Species Affected 193 & $\begin{array}{l}\text { Review } \\
\text { Length }\end{array}$ & Status \\
\hline $\begin{array}{l}\text { Tule Wind } \\
\text { Project } 194\end{array}$ & $\begin{array}{l}\text { Consultation relating to } \\
\text { construction and operation } \\
\text { of a 186 MW wind energy } \\
\text { facility, comprising 128 wind } \\
\text { turbines, 3 meteorological } \\
\text { towers, transmission lines, a } \\
\text { substation, and associated } \\
\text { infrastructure, in San Diego } \\
\text { County, California }\end{array}$ & 2011 & $\begin{array}{l}\text { Quino checkerspot } \\
\text { butterfly } \\
\text { (Euphydryas editha } \\
\text { quino }\end{array}$ & 355 days & $\begin{array}{l}\text { Under } \\
\text { construction }\end{array}$ \\
\hline $\begin{array}{l}\text { Ocotillo } \\
\text { Express } \\
\text { Wind } \\
\text { Project }{ }^{195}\end{array}$ & $\begin{array}{l}\text { Consultation relating to } \\
\text { construction and operation } \\
\text { of a 356.5 MW wind energy } \\
\text { facility, comprising 155 wind } \\
\text { turbines, 3 meterological } \\
\text { towers, transmission lines, a } \\
\text { substation, and associated } \\
\text { infrastructure, in Imperial } \\
\text { County, California }\end{array}$ & 2012 & $\begin{array}{l}\text { Peninsular bighorn } \\
\text { sheep, least bell's } \\
\text { vireo (Vireo bellii } \\
\text { pusillus) }\end{array}$ & 336 days & $\begin{array}{l}\text { Operations } \\
\text { began in }\end{array}$ \\
\hline Searchlight & $\begin{array}{l}\text { Consultation relating to } \\
2012^{196}\end{array}$ & 2012 \\
\hline
\end{tabular}

62 | Protecting Species or Endangering Development | August 2016 


\begin{tabular}{|c|c|c|c|c|c|}
\hline Title & Description & Year & Species Affected ${ }^{193}$ & $\begin{array}{l}\text { Review } \\
\text { Length }\end{array}$ & Status \\
\hline $\begin{array}{l}\text { Wind Energy } \\
\text { Project }^{197}\end{array}$ & $\begin{array}{l}\text { construction and operation } \\
\text { of a } 200 \mathrm{MW} \text { wind energy } \\
\text { facility, comprising up to } 87 \\
\text { wind turbines, transmission } \\
\text { lines, substations, access } \\
\text { roads, and associated } \\
\text { infrastructure, in Clark } \\
\text { County, Nevada }\end{array}$ & & tortoise & & $\begin{array}{l}\text { approval } \\
\text { vacated by } \\
\text { the U.S. } \\
\text { District } \\
\text { Court in } \\
\text { November } \\
2015^{198}\end{array}$ \\
\hline $\begin{array}{l}\text { Chokecherry } \\
\text { and Sierra } \\
\text { Madre Wind } \\
\text { Energy } \\
\text { Project }^{199}\end{array}$ & $\begin{array}{l}\text { Consultation relating to } \\
\text { construction and operation } \\
\text { of a 2,000 to } 3,000 \mathrm{MW} \text { wind } \\
\text { energy facility, comprising up } \\
\text { to } 1,000 \text { wind turbines and } \\
\text { associated infrastructure, in } \\
\text { Carbon County, Wyoming }\end{array}$ & 2012 & $\begin{array}{l}\text { Endangered } \\
\text { Colorado River } \\
\text { Fish Species, Platte } \\
\text { River Fish and Bird } \\
\text { Species, western } \\
\text { prairie fringed } \\
\text { orchid (Platanthera } \\
\text { praeclara) }\end{array}$ & 9 days & $\begin{array}{l}\text { BLM yet to } \\
\text { approve } \\
\text { project }\end{array}$ \\
\hline $\begin{array}{l}\text { Southern } \\
\text { California } \\
\text { Edison } \\
\text { Switchyards } \\
200\end{array}$ & $\begin{array}{l}\text { Consultation relating to } \\
\text { operation and maintenance } \\
\text { of existing switchyards } \\
\text { supporting wind generators } \\
\text { in Palm Springs, California }\end{array}$ & 2012 & $\begin{array}{l}\text { Coachella Valley } \\
\text { fringe-toed lizard } \\
\text { (Uma inornata), } \\
\text { Coachella Valley } \\
\text { milk-vetch } \\
\text { (Astragalus } \\
\text { lentiginosus var. } \\
\text { coachellae) }\end{array}$ & 25 days & Operational \\
\hline
\end{tabular}




\begin{tabular}{|l|l|l|l|l|l|}
\hline Title & Description & Year & Species Affected 193 & $\begin{array}{l}\text { Review } \\
\text { Length }\end{array}$ & Status \\
\hline $\begin{array}{l}\text { Alta East } \\
\text { Wind } \\
\text { Project } 201\end{array}$ & $\begin{array}{l}\text { Consultation relating to } \\
\text { construction and operation } \\
\text { of a 153 MW wind energy } \\
\text { facility, comprising up to 51 } \\
\text { wind turbines, } 2 \\
\text { meteorological towers, a } \\
\text { substation, and associated } \\
\text { infrastructure, in Kern } \\
\text { County, California }\end{array}$ & 2013 & $\begin{array}{l}\text { Bakersfield cactus, } \\
\text { California condor } \\
\text { (Gymnogys } \\
\text { californianus), desert } \\
\text { tortoise }\end{array}$ & 140 days & Operational \\
\hline
\end{tabular}

All of the projects listed in Table 7, except the "Chokecherry and Sierra Madre Wind Energy Project," underwent the traditional formal consultation process. In each consultation, FWS undertook a comprehensive review of the project, including a detailed analysis of its likely effects. Based on its review, FWS concluded that, while the project may adversely affect one or more listed species, it was unlikely to jeopardize the continued existence of those species, given the conservation measures to be implemented by the developer. The conservation measures varied significantly between projects, likely reflecting differences in the species affected. Examples of conservation measures incorporated into wind energy projects include requirements to:

- avoid siting wind turbines on or immediately adjacent to the upsides of ridge crests;

- curtail turbine operation at designated times (e.g., when birds are detected in the area);

- bury power collection lines to reduce opportunities for perching by birds of prey;

- minimize night lighting to avoid unnecessary visual disturbance to listed species;

- perform species surveys and relocate species away from project area;

- $\quad$ restrict vehicle traffic and speeds;

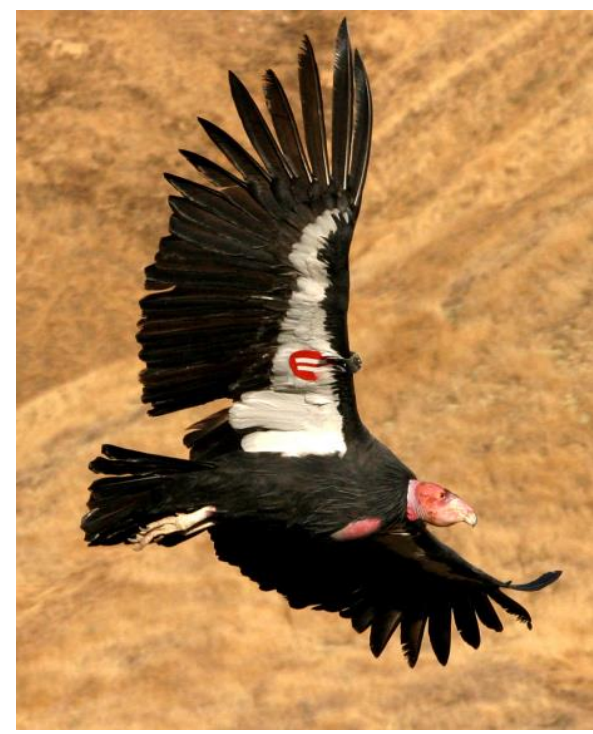

California Condor 


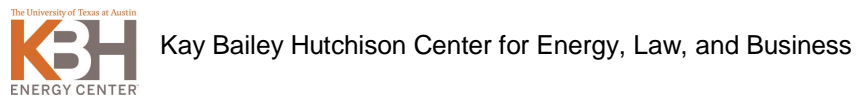

- provide workers with training on the conservation measures; and

- appoint a biologist to monitor compliance with the conservation measures;

65 | Protecting Species or Endangering Development | August 2016 


\section{Case Study 12: Tule Wind Project in Southern California}

- Proposed Action: BLM grant of a ROW authorizing construction and operation of a $186 \mathrm{MW}$ wind energy facility, including 128 wind turbines, 3 meteorological towers, overhead transmission lines, substation facilities, and associated infrastructure, in San Diego County in southern California.

- Species Affected: Quino checkerspot butterfly

- Type of Consultation: Formal

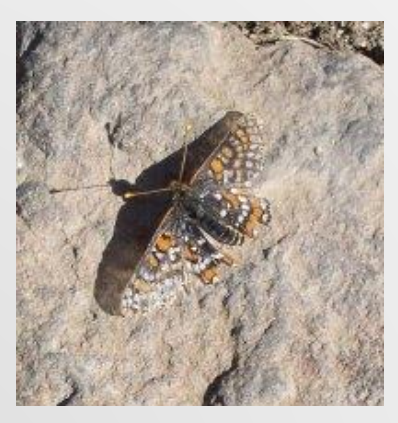

Quino Checkerspot Butterfly

- Length of Consultation: 335 days (from receipt of the request for consultation $(9 / 8 / 10)$ to issuance of the $\mathrm{BO}(9 / 2 / 11))$

- Pre-consultation Discussions: 10 months. On December 10, 2009, FWS received a request for a species list for the project. The list, which was provided to BLM on February 1, 2010, indicated that Quino checkerspot butterflies may be present in the project area. The area was then surveyed and a small number of adult Quino, and plants capable of supporting Quino larvae, were identified.

- $\quad \boldsymbol{F W S}$ Determination: The project is not likely to jeopardize listed species.

- Reasons for Determination: The project affects a relatively small amount of Quino habitat. The project proponent agreed to implement various measures to minimize direct mortality of Quino eggs, larvae pupae, and adults and avoid indirect effects. These included compensating for any permanent habitat loss resulting from the project (at a ratio of 2:1), avoiding project activities during the butterfly flight season and in occupied butterfly habitat, minimizing the creation of dust clouds, restricting vehicle traffic and speeds, and taking steps to prevent and treat weed infestations.

\section{(B) Programmatic Consultations}

One formal consultation, relating to the Chokecherry and Sierra Madre Wind Energy Project, proceeded on an expedited basis under the RIP and PRRIP. The RIP and PRRIP aim to protect fish and bird from the impacts of declining water flows in the Upper Colorado and Platte River basins respectively. Water resources in those basins have become degraded in recent years due, in part, to the construction of dams and other structures which have altered hydrological conditions. This, together with increasing water withdrawals from the basins, has caused local fish and bird populations to decline. Seeking to reverse this decline, FWS partnered with other 
government agencies to develop and implement the RIP and PRRIP, aimed at maintaining water flows.

The Chokecherry and Sierra Madre Wind Energy Project proposed to use water from the Upper Colorado River and Platte River basins for dust suppression, equipment washing, and potable and sanitary services. ${ }^{202}$ BLM determined that project-related water withdrawals may adversely the four Endangered Colorado River Fish and Platte River Bird and Fish Species. It therefore requested formal consultation with FWS. In undertaking the consultation, FWS followed the streamlined process established in the RIP and PRRIP, described in section (VI)(B).

FWS concluded that the RIP and PRRIP can serve as the reasonable and prudent alternative to mitigate the impact of project-related water withdrawals on listed species. FWS did not conduct a detailed assessment of the effects of project-related water depletions on listed species, nor identify project-specific conservation measures to offset those effects. Rather, FWS concluded that the RIP and PRRIP adequately address effects to the species and, as a result, "[n]o additional conservation measures are needed to reduce impacts from the proposed action." FWS was, therefore, able to complete its review quickly, issue its BO just nine days after receiving BLM's request for consultation. In comparison, the other five formal consultations relating to wind energy projects took significantly longer, lasting an average of 204 days.

\section{(C) Informal Consultations}

Of the nine consultations relating to wind energy projects, undertaken between FY2010 and FY2014, three (thirty-three percent) proceeded on an informal basis. Details of each informal consultation are provided in Table 8 below.

TABLE 8: INFORMAL CONSULTATIONS INVOLVING WIND ENERGY DEVELOPMENT ON BLM LANDS

\begin{tabular}{|l|l|l|l|l|}
\hline Title & Description & Year & Species Affected 203 & $\begin{array}{l}\text { Review } \\
\text { Length }\end{array}$ \\
\hline $\begin{array}{l}\text { Graham Pass } \\
\text { Wind Testing } \\
\text { and Monitoring } \\
\text { Project } 204\end{array}$ & $\begin{array}{l}\text { Consultation relating to } \\
\text { installation of 2 temporary } \\
\text { meteorological towers for } \\
\text { wind monitoring and testing } \\
\text { in Riverside County, } \\
\text { California }\end{array}$ & 2011 & Mojave desert tortoise & 136 days \\
\hline $\begin{array}{l}\text { Andy Johnson } \\
\text { Wind }\end{array}$ & $\begin{array}{l}\text { Consultation relating to } \\
\text { installation of 1 temporary }\end{array}$ & 2012 & Mojave desert tortoise & 103 days \\
\hline
\end{tabular}

67| Protecting Species or Endangering Development | August 2016 


\begin{tabular}{|l|l|l|l|l|}
\hline Title & Description & Year & Species Affected 203 & $\begin{array}{l}\text { Review } \\
\text { Length }\end{array}$ \\
\hline $\begin{array}{l}\text { Meteorological } \\
\text { Tower } 205\end{array}$ & $\begin{array}{l}\text { meteorological tower in } \\
\text { Riverside County, California }\end{array}$ & 2012 & $\begin{array}{l}\text { Lesser long-nosed bat } \\
\text { (Leptonycteris curasoae } \\
\text { yerbabuenae) }\end{array}$ & 24 days \\
\hline $\begin{array}{l}\text { Greyback } \\
\text { Meuntain } \\
\text { Toweorological }\end{array}$ & $\begin{array}{l}\text { Consultation relating to } \\
\text { installation of 1 temporary } \\
\text { meteorological tower in Pinal } \\
\text { County, Arizona }\end{array}$ & and & & \\
\hline
\end{tabular}

The three informal consultations each involved site testing and monitoring activities. Such activities constitute the first step in developing a new wind energy project, and involve erecting one or more towers equipped with weather instruments to collect meteorological data, such as wind speed and direction, wind shear, temperature, and humidity. This data is used by the project proponent to determine whether wind resources at a particular site are suitable for development and, if so, the appropriate type, number, and location of wind turbines at the site.

Site testing and monitoring activities typically result in minimal land disturbance. Most meteorological towers are installed only temporarily and, as such, do not require subsurface foundations. ${ }^{207}$ Towers can generally be erected by a small crew, often in less than one day, and without using large-scale equipment. ${ }^{208}$ As a result, existing roads can generally be used to access the site. Only in the most remote locations, where there is no existing access, may basic roads need to be constructed. 209 There is generally no need to construct accessory infrastructure or buildings at the site. ${ }^{210}$

Given the above, BLM has taken the view that any impacts to listed species from site testing and monitoring activities are likely to be minimal. ${ }^{211}$ Consistent with that view, where site testing and monitoring activities are involved, BLM typically only consults with FWS informally. In the three informal consultations undertaken between FY2010 and FY2014, FWS concurred with BLM's view that the activities would not adversely affect listed species, eliminating the need for further consultation on a formal basis. 


\section{Case Study 13: Graham Pass Wind Project in California}

- Proposed Action: BLM approval of phase 1 of the Graham Pass Wind Project, involving the installation of temporary meteorological towers and performance of bird and bat acoustic studies in Riverside County in California, to determine the suitability of the site for phases 2 and 3 of the project, involving construction of a 30,800 acre wind farm

- Species Affected: Mojave desert tortoise

- Type of Consultation: Informal

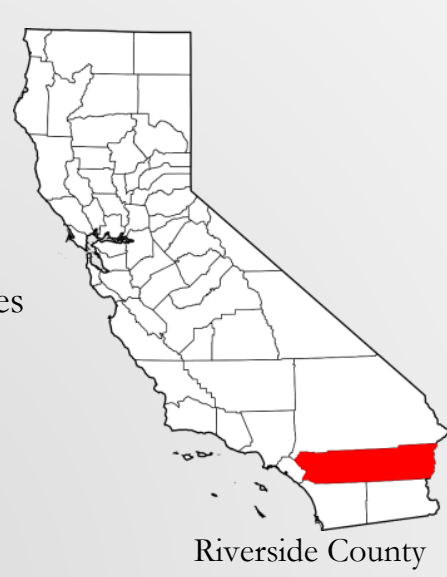

- Length of Consultation: 136 days (from receipt of the request for consultation $(7 / 13 / 11)$ to issuance of the concurrence letter $(11 / 28 / 11)$

- Pre-consultation Discussions: Unknown

- $\quad \boldsymbol{F W S}$ Determination: Phase 1 of the project is not likely to adversely affect listed species. FWS did, however, express concern about the potential impacts of phases 2 and 3. FWS recommended that BLM reconsider approving phase 1 pending further discussions and research on the compatibility of utility wind energy development with desert tortoise conservation.

- Reasons for Determination: The project proponent agreed to incorporate various avoidance and minimization measures into phase 1 of the project. These included, among other things, surveying the project area for desert tortoise, flagging desert tortoise habitat features, confining surface disturbance to the smallest practical area,

\section{Discussion}

As the foregoing discussion indicates, only a small number of energy projects on BLM land were subject to consultation under section 7 of the ESA, between FY2010 and FY2014. Over that period, however, the annual number of energy project consultations has increased. This increase is attributable largely to growth in the number of consultations on renewable energy projects. In recent years, BLM land in the western U.S. has been the site of significant renewable energy development. Seeking to reduce U.S. dependence on foreign oil, diversify the nation's energy portfolio, and combat carbon emissions, the federal government has taken various steps to encourage such development, including by providing tax incentives therefor. ${ }^{212}$

These tax incentives have spurred significant renewable energy development, much of which has occurred on public lands. The Energy Policy Act of 2005 established a goal for the Secretary of 
the Interior to approve 10,000 MWs of electricity from non-hydropower renewable energy projects on public lands by 2015. The DOI achieved the goal ahead of schedule in October 2012.213 Building on these efforts, the President's Climate Action Plan, released in 2013, directed the DOI to approve an additional 10,000 MW of renewable energy capacity on public lands by $2020 .{ }^{214}$

The goal of all these policies is to increase development of renewable energy. As development increases, however, so do the pressures on landscapes and ecosystems. As discussed in section III, under FLPMA, BLM has the responsibility to ensure that public lands "are managed in a manner that will protect the quality of scientific, scenic, historical, ecological, environmental, air and atmospheric, water resource and archeological values." ${ }^{215}$ In response to the surge of renewable energy development over the last decade, BLM has developed policies to ensure that renewable energy development does not take place in a manner that is harmful to public lands. The section 7 consultation process has been shaped by these policies.

\section{(A) Recent Energy Project Consultations}

Between FY2010 and FY2014, thirty-six consultations were undertaken with respect to renewable energy development, of which seventy-five percent involved solar energy projects, and twenty-five percent involved wind energy projects. Our research indicates that most recent renewable energy projects have been subject to formal consultation. By way of example, we estimate that approximately eighty-two percent of solar energy and seventy-one percent of wind energy developments approved by BLM between FY2010 and FY2014 were subject to formal consultation.

Compared to renewable energy developers, the oil and gas industry has had less experience with the ESA. Industry representatives interviewed for this study reported that, in the past, there has been little overlap between oil and gas activities and endangered species habitat. Whether this is by accident or design is difficult to conclusively determine. Industry reports suggest that, at least in some circumstances, oil and gas companies may purposely relocate and/or otherwise redesign projects so as to avoid impacts to species habitat. In other situations, however, it may simply be a coincidence that the areas selected for oil and gas projects are located outside species habitat.

Given the above, it is perhaps unsurprising that only a small proportion of recent oil and gas projects on BLM lands have been subject to consultation under section 7 of the ESA. As shown in Table 3 above, of the nearly 20,000 oil and gas wells approved for drilling on BLM lands between FY2010 and FY2014, just ten percent were subject to ESA consultation. In total, there were 143 consultations relating to oil and gas drilling and associated activities.

70 | Protecting Species or Endangering Development | August 2016 
None of the energy projects subject to consultation were found to jeopardize listed species or destroy or adversely modify critical habitat. All projects were, therefore, allowed to proceed without substantial modification. Notably however, through discussions with FWS staff, we learned that some projects were cancelled by the developer during or after consultation. It is not possible, based on the data obtained from FWS, to ascertain the exact number of cancelled projects. Nor is it possible to determine the reasons for cancellation. Although most cancellations are likely to have been made for financial or other business reasons, it could be that some occurred in response to concerns expressed by FWS, regarding the potential for jeopardy to listed species.

Based on discussions with agency staff and industry representatives, it is our impression that the consultation process is highly collaborative, often involving significant back-and-forth between FWS, BLM, and the project proponent. This is particularly true with respect to renewable energy projects. The novelty of such projects on public lands, as well as their massive size and inevitable impact to species habitat, means considerable effort and time on behalf of all parties to develop conservation measures. This has, on occasion, led to substantial delays, as in the case of the Ivanpah Solar Energy Project (discussed in Case Study 9) and Tule Wind Energy Project (discussed in Case Study 12), and/or major changes to the project location and footprint, as occurred with the Stateline and Silver State South Projects (discussed in Case Study 10).

\section{(B) Industry Complaints About the Consultation Process}

Despite the fact that no projects were stopped by the ESA, implementation of the Act may nevertheless hinder energy development in some circumstances. Industry representatives interviewed for this study emphasized that the consultation requirement, in section 7 of the ESA, can and often does lead to significant project delays. This claim has been disputed by environmentalists, who argue that most consultations are completed within the time limits set in the ESA. Our research shows that most formal consultations relating to oil and gas projects were completed within the statutory time limits. Notably however, consultations relating to renewable energy projects often took significantly longer, likely as a consequence of the sheer size of the projects and resulting impacts to listed species.

Even where the statutory time limits are officially met, projects delays may occur as a result of lengthy pre-consultation discussions, undertaken before the time limits are triggered. By way of example, in 2010, FWS and BLM consulted on the Black Hills WPMDP (discussed in Case Study 4). Consultation on the plan was officially initiated on April 1, 2010 and was concluded 106 days later. Prior to the official start of consultation, however, there were significant discussions between BLM and FWS. When these pre-consultation discussions are included, the total length of the process exceeded 250 days.

71 | Protecting Species or Endangering Development | August 2016 
Typically, during pre-consultation discussions, BLM and FWS will exchange information about the proposed project, assess its likely effects on listed species, and agree on conservation measures to mitigate those effects. The project proponent may be directly involved in this process or, if not so involved, kept informed by BLM. In speaking with industry representatives about the process, a common criticism we heard related to difficulties in dealing with FWS. Many noted that different FWS staff members often adopt varying interpretations of the ESA and/or may differ in their assessment of project effects and the conservation measures required to offset those effects. This can result in inconsistent treatment of similar projects.

\section{(C) The Benefits of a Programmatic Approach}

Inconsistencies do not arise, to the same extent, where projects are covered by a PBO. FWS has recently issued a number of PBOs which cover multiple actions of the same type or in the same area. When a covered action is proposed, BLM and FWS may agree to append that action to the existing PBO, or use the PBO as a foundation for further analysis. This should result in greater consistency in the treatment of each action. Indeed, as one industry representative interviewed for this study noted, the existence of a PBO can remove much of the "subjectivity that can be injected [into consultations] by individual staff." Others however, warned that this is not always the case and that the PBO may be subject to different interpretations over time, particularly when there is staff turnover.

The agency staff and industry representatives we interviewed generally agreed that the existence of a PBO greatly streamlines the consultation process. This is confirmed by our research. As an example, between FY2010 and FY2014, twenty-one oil and gas projects and one wind energy project were subject to consultation under the RIP and PRRIP. All of those consultations were completed quickly, with the longest lasting ninety-seven days, well within the statutory (135 day) time limit. Across all twenty-two consultations, the average length of review was just twentyseven days, calculated from the date consultation was officially requested. We understand from discussions with agency staff and industry representatives that there are generally no or few preconsultation discussions for projects covered by the RIP and PRRIP.

Specific programmatic consultations have been undertaken with respect to renewable energy projects on BLM lands. By way of example, as part of its Wind Energy Development Program, BLM consulted with FWS on the likely impact of future wind energy projects on nine endangered and threatened species. To minimize any adverse impacts on those species, various BMPs were developed, for wind energy projects. Those BMPs continue to guide the conservation measures adopted in individual project consultations. This not only provides greater certainty for developers, but should also ensure that the consultation process runs more smoothly.

72 | Protecting Species or Endangering Development | August 2016 
Similar efforts have also been taken to streamline consultation on solar energy projects. Before development of BLM's Solar Energy Program, designating preferred SEZs, FWS had to ensure that the location of projects would not interfere with habitat connectivity for the Mojave desert tortoise. On occasion this meant that, during the consultation process, the project footprint or location of the project had to be altered, as occurred in the Stateline and Silver State South projects (see Case Study 10). With the development of BLM's Solar Energy Program and FWS's Solar PBO, developers should have more certainty over the landscape level conservation measures with which they will be required to comply. The hope is that this will make the formal consultation process run more efficiently, while ensuring adequate protection of listed species and the ecosystems on which they depend.

\section{Conclusion}

Section 7 consultation is designed to ensure that actions authorized, funded, or carried out by federal agencies do not jeopardize the continued existence of listed species or destroy or adversely modify critical habitat. Despite this laudable aim, the consultation process has come under increasing criticism in recent years, particularly from the energy industry. Industry representatives have argued that consultation frequently stops or delays energy development and may lead to significant added costs for developers.

Seeking to assess the impact of section 7 consultation on energy development on public lands, we reviewed 179 consultations undertaken with respect to oil, gas, solar, and wind energy projects on BLM land between FY2010 and FY2014. Key findings from our review include:

- Only a relatively small number of consultations have been undertaken with respect to energy development on BLM land over the last five years. The bulk (seventy-eight percent) of these consultations involved oil and gas projects. Notably however, the oil and gas projects subject to consultation represent just ten percent of those permitted by BLM. A larger proportion of BLM permitted solar (eighty-two percent) and wind energy projects (seventy-one percent) were subject to consultation.

- Most consultations were completed within the time limit set in the ESA. There are, however, often pre-consultation discussions during which significant time and effort may be devoted to formulating conservation measures to protected listed species. This enables such measures to be built into the project design, which not only protects listed species, but also helps to reduce project costs. It can lead to delays, however.

- Although detailed procedures for consultation have been set out in regulations, in practice, the process often varies significantly between and within FWS offices. This is a concern for

73 | Protecting Species or Endangering Development | August 2016 
industry, which has emphasized the potential for inconsistent treatment of similar projects, and the uncertainty resulting therefrom.

- Responding to industry concerns, FWS has issued a number of PBOs, covering multiple similar actions. Many of these PBOs have been developed in the context of broader government reviews into energy development on BLM lands. As part of these reviews, BLM develops policies to facilitate responsible development of energy projects on public lands and FWS analyzes the landscape level impacts of these policies.

- Where a project is covered by a PBO, consultation tends to proceed more quickly, and there is less need for pre-consultation discussion. The existence of a PBO can also greatly reduce the complexity of consultation and generally leads to increased certainty for project developers. 


\section{Appendix 1: Case Studies}

\section{CASE STUDY 1: NOVEMBER 2013 OIL AND GAS LEASE SALE IN CENTRAL UTAH}

In November 2013, BLM's Utah Field Office conducted an oil and gas lease sale, covering eighty-two parcels of land, with a combined area of 143,981 acres, in Carbon, Duchesne, Emery, and Uintah Counties. ${ }^{216}$ Several of the parcels contained habitat for endangered and threatened species. ${ }^{217}$ BLM concluded that leasing the parcels may affect species and therefore consulted with FWS under section 7 of the ESA.

ESA consultation proceeded on an informal basis, with FWS concurring with BLM that the lease sale was unlikely to adversely affect listed species. ${ }^{218} \mathrm{FWS}$ issued its concurrence letter thirteen days after receiving BLM's request for consultation. This quick turnaround was possible as FWS did not undertake a detailed analysis of the likely impacts of development on lease parcels, but rather merely sought to confirm that each parcel incorporated lease notices, developed through a series of earlier programmatic consultations. ${ }^{219}$

The programmatic consultations were completed in 2008 in connection with the adoption of RMPs by BLM's Utah office. As part of the consultation, FWS reviewed the likely impact of actions authorized under the RMPs, including lease sales. ${ }^{220}$ FWS developed, in cooperation with BLM, on a number of species-specific lease notices to be attached to lease parcels. ${ }^{221}$ The notices are designed to inform the lessee that the parcels may contain habitat for listed species and outline conservation measures that may be imposed to protect those species.222 The conservation measures vary, but typically include:

- a requirement to conduct surveys for listed species prior to commencing lease activities;

- restrictions on the location and/or timing of activities to minimize impacts to listed species;

- measures to avoid the loss of, or damage to, listed species' habitat; and

- a requirement to monitor the impact of lease activities on listed species and habitat. ${ }^{223}$

According to FWS, these "lease notices ensure effects [to listed species] are avoided or minimized during energy development planning, exploration, extraction, and production activities" on the lease parcel. ${ }^{224}$ Therefore, provided the notices are attached, lease sales are not likely to adversely affect listed species. Informal consultation is conducted prior to each lease sale to ensure that the notices have been attached.

We understand, from discussions with agency staff, that there is typically some discussion between BLM and FWS prior to the initiation of consultation. For lease sales in Utah, BLM will typically provide FWS with information on the parcels to be offered, approximately nine months before the sale. FWS will also be provided, approximately six months before the sale, with a

75 | Protecting Species or Endangering Development | August 2016 
copy of BLM's draft environmental assessment. Sometime later, generally six weeks before the lease sale, BLM will file a request for informal consultation with FWS.

During informal consultation, FWS does not undertake a detailed analysis of the likely impacts of oil and gas development on the lease parcels. Rather, FWS merely seeks to confirm that the appropriate lease notices have been attached to each parcel. The consultation process can, therefore, generally be completed quickly. Consultation on the November 2013 Oil and Gas Lease Sale, for example, was completed in just thirteen days. 225

In addition to simplifying consultation on lease sales, the notice system also has other benefits, giving potential lessees advance warning of the conservation measures they may be required to implement in future projects. In this regard, FWS has observed that "[] will...provide full disclosure to the lessee of potential environmental concerns and strategies to minimize effects to listed species. This will allow the industry to consider environmental issues prior to finalizing development plans, and thus minimize financial and logistical planning burdens." 226

\section{CASE STUDY 2: PROGRAMMATIC CONSULTATION ON SMALL OIL AND GAS PROJECTS IN SOUTHERN CALIFORNIA}

FWS has completed a programmatic consultation on small-scale oil and gas projects undertaken in California's Central Valley. This area provides habitat for eight endangered species, namely:

- the blunt-nosed leopard lizard (Gambelia silus), a large lizard which has a long regenerative tail, a short blunt snout, and yellowish or brown back, with alternating dark and light spots; 227

- the giant kangaroo rat (Dipodomys ingens), a brown rodent measuring approximately six inches in length, with large hind limbs, smaller forelimbs, a short neck, flat head, and long tufted tail; 228

- the Tipton kangaroo rat (Dipodomys nitratoides nitratoides), a small brown rodent, which has small forefeet, large hind feet, and a long tail;229

- the San Joaquin kit fox (Vulpes macrotis mutica), a small gray canid, with large ears and a long bushy tail;230

- the Bakersfield cactus (Opuntia basilaris), a perennial low growing cactus with fleshy, flat green pads that produce bright magenta flowers in spring and summer; 231

- the California jewelflower (Caulanthus californicus), an annual herb which has a branched stem, with oval-shaped toothed leaves and flattened, sword-shaped fruit;232

76 | Protecting Species or Endangering Development | August 2016 
- the Kern mallow (Eremalche kiernensis), a small flowering annual which grows to approximately twenty inches in height and has small white or pink flowers on slender branches; 233 and

- the San Joaquin wooly-threads (Monolopia congdoniz), a member of the sunflower family, which produces trailing or upright stems covered in wooly fibers and tipped with yellow flowers 234

(together the "Central Valley Endangered Species").

Due to their potential impact on the Central Valley Endangered Species, prior to authorizing oil and gas projects, BLM must typically consult with FWS under the ESA. Prior to 1996, consultation occurred on a project-by-project basis. This approach was extremely timeconsuming, with each consultation lasting a minimum of three months, and often up to one year. Seeking to streamline the process, in July 1996, FWS issued a PBO consolidating consultation on certain projects in the Central Valley. The PBO had an initial term of five years, ending in 2001,235 but was subsequently extended for a further fifteen years to 2016. ${ }^{236}$ At the time of writing, FWS and BLM were negotiating a second extension, to take effect in 2016.

The PBO provides for streamlined review of small-scale oil and gas projects in Kings and Kern Counties in California. 237 It applies where BLM proposes to authorize a project, which will disturb less than ten acres of habitat, or a linear action that is less than ten miles in length.238 BLM may authorize such projects under the PBO, provided that the total amount of disturbance does not exceed 690 acres per year, and the amount of new surface disturbance does not exceed 115 acres per year. ${ }^{239}$ If these annual limits are reached, BLM must contact FWS before proceeding with further authorizations. 240

Projects meeting the requirements of the California Oil and Gas PBO can be appended thereto. ${ }^{241}$ We understand from discussions with agency staff that, prior to appending a project to the PBO, BLM will notify FWS. Although FWS has the option of reviewing each project, due to staffing constraints, this rarely occurs. Most projects are reviewed solely by BLM, which confirms that the project is covered by the $\mathrm{PBO}$, and then issues a confirmation letter to this effect. BLM aims to issue the confirmation letter within 30 to 60 days.

Each project appended to the PBO must incorporate the conservation measures specified therein. The measures require the project proponent to:

- conduct surveys to determine the presence of listed species and identify key habitat features; 242

- minimize the amount of surface disturbance associated with the project;

- mitigate the impact of the project on listed species and habitat, including by protecting key habitat features within the project area, relocating species away from the project area, and limiting activities during species breeding and other key life stages; and 
- compensate for any loss of habitat by acquiring land, with the same habitat features, and transferring it to an approved entity. Where the project adversely affects previously undisturbed habitat, ${ }^{243}$ compensation must generally ${ }^{244}$ be provided at a ratio of $3: 1$ for permanent impacts and 1.1:1 for temporary impacts. ${ }^{245}$ For protected lands, a replacement component (at a ratio of 1:1) must be added to the compensation ratios.

A total of 458 projects were appended to the California Oil and Gas PBO between FY2010 and FY2014. Over two-fifths of those projects involved the drilling of oil and gas wells. The remaining projects covered a range of activities, including well pad construction, tank installation, power system upgrade, pipeline construction, and road improvement.

\section{CASE STUDY 3: WHITEWATER UNIT MASTER DEVELOPMENT PLAN}

The Whitewater Unit Master Development Plan ("MPD”) was developed by Fram Operating LLC ("Fram") and submitted to BLM for approval in August 2011.246 The MPD proposed a four-year program of oil development in the Whitewater Unit, located approximately fifteen miles south east of the City of Grand Junction in western Colorado.247 The Whitewater Unit covers an area of 90,400 acres and includes a mixture of public, private, and split estate lands. ${ }^{248}$ Under the MPD, Fram proposed to drill 108 wells on twelve well pads, on federal and private land. ${ }^{249}$

The MPD replaced a larger development proposal for the Whitewater Unit submitted to BLM by Fram in 2010.250 The 2010 proposal outlined a five-year program of oil exploration, consisting of the drilling of 492 wells on fifty-five well pads in Mesa and Delta Counties. ${ }^{251}$ Due to market uncertainties and resource concerns, Fram subsequently decided not to drill in the southern half of the Whitewater Unit, and instead confined its operations to 52,500 acres of land in Mesa County. ${ }^{252}$ Fram's revised proposal was set out in the 2011 MPD.

Fram submitted the MPD to BLM on August 17, 2011.253 We understand from agency staff that, prior to submitting the MPD, Fram had initial scoping discussions with BLM. Following these discussions, at BLM's request, Fram engaged WestWater Engineering to survey the plan area.254 The survey report, which was submitted to BLM on September 12, 2011, indicated that the plan area contained over 8,800 plants thought to be Colorado hookless cactus. ${ }^{255}$ Listed as a threatened species in 1979, the Colorado hookless cactus is a barrel-shaped spiny plant, typically identified by its fragrant pink flowers. ${ }^{256}$ In this case however, certain areas were surveyed outside the Colorado hookless cactus flowering season making a definitive identification difficult. ${ }^{257}$ Nevertheless, BLM considered all hard barrel cactus found in the area to be Colorado hookless cactus. ${ }^{258}$

Due to the presence Colorado hookless cactus in the plan area, BLM staff contacted FWS on an unofficial basis, in or around March 2012.259 During these initial discussions, FWS provided advice on setbacks and other measures to minimize the impacts of well drilling and associated

78 | Protecting Species or Endangering Development | August 2016 
activities on Colorado hookless cactus. ${ }^{260}$ Based on FWS's advice and input from other stakeholders, BLM worked with representatives of Fram, to alter the design of the project, so as to lessen impacts to sensitive species.

Once the project design was agreed, BLM worked with environmental consultants hired by Fram to prepare a biological assessment, with respect to the MPD. The biological assessment covered potential impacts to the Colorado hookless cactus and four Endangered Colorado River Fishes. ${ }^{261}$ The fish species were included due to the potential water quantity and quality impacts of oil development under the MPD. ${ }^{262}$ BLM determined that up to 13.88 acre-feet of water per year would be pumped from surface water bodies for use in well drilling and completion, pipeline testing, and dust control.263

The biological assessment was received by FWS, along with a request for initiation of formal consultation, on March 29, 2013. ${ }^{264}$ From that date, formal consultation lasted 160 days, with FWS issuing its BO on September 2, 2013. This is somewhat longer than other formal consultations. According to agency staff involved in the consultation, Fram requested that FWS prioritize review of other projects, leading to delays in issuance of the BO on the MPD.

\section{CASE STUDY 4: BLACK HILLS WESTERN PROPERTIES MASTER DEVELOPMENT PLAN}

The Western Properties Master Development Plan ("WPMDP”), developed by Black Hills Corporation, proposed a five-year program of oil and gas extraction. ${ }^{265}$ The program consisted of the drilling of up to 107 oil and gas wells on 12 existing and 67 new well pads, as well as the construction of pipelines, roads, and other associated facilities. ${ }^{266}$ These activities were to occur in an area, encompassing roughly 25,000 acres of federal mineral estate, in Garfield and Mesa Counties in western Colorado. ${ }^{267}$ The project area included 685 acres of currently disturbed ground and was expected to result in the disturbance of an additional 509 acres. ${ }^{268}$

The project area was believed to contain Colorado hookless cactus. ${ }^{269}$ Surveys conducted in portions of the project area between 2007 and 2009 identified 893 live cactus plants. ${ }^{270}$ Based on these results, BLM estimated that there were 1,700 plants in the unsurveyed portion of the project area, within 100 meters of proposed development. ${ }^{271}$ BLM concluded that these plants may be adversely affected by development and engaged in formal consultation with FWS.

On April 1, 2010, BLM requested that FWS initiate formal consultation to assess the effects of development on the Colorado hookless cactus and four Endangered Colorado River Fishes. BLM's request also sought informal consultation with respect to another plant, the DeBeque phacelia (Phacelia submutica), potentially affected by development. ${ }^{272}$ The DeBeque phacelia is a small herbaceous annual which grows solely in the alkaline clay soils of the southern Piceance Basin in Garfield and Mesa Counties in Colorado. ${ }^{273}$ Since the WPMDP envisaged development

79 | Protecting Species or Endangering Development | August 2016 
in those counties, BLM determined that it may affect the DeBeque phacelia and requested consultation thereon.

Prior to filing the official request for consultation, BLM had contacted FWS about the WPMDP. In October 2009, FWS was involved in a visit to the proposed development site. Following the site visit, FWS was provided with information about the WPMDP and asked to comment on a draft biological assessment prepared by BLM in February 2010. FWS provided comments on the draft biological assessment, which was then finalized by BLM, and officially submitted to FWS in April 2010, with the request for consultation. FWS issued a BO, with respect to the WPMPD, on July 15, 2010. From the date of first contact, then, FWS's review process lasted a total of 271 days. ${ }^{274}$

In its BO, FWS concurred with BLM's view that development under the WPMDP was unlikely to adversely affect the DeBeque phacelia. ${ }^{275}$ With respect to the Colorado hookless cactus, FWS indicated that development may adversely affect the species, but was unlikely to jeopardize its continued existence. ${ }^{276}$ FWS noted that no removal or other direct impacts to Colorado hookless cactus had been proposed. ${ }^{277}$ According to FWS, cactus plants may be impacted indirectly by "heavy dust created during construction activities," as well as "changes in hydrology and soil characteristics, an increase in competitive noxious weeds, and alterations of vegetation cover and species composition." 278 These impacts would, however, be minimized through the adoption of various conservation measures proposed by BLM and Black Hills. ${ }^{279}$

Notably, to minimize impacts to Colorado hookless cactus, Black Hills agreed that future developments under the WPMDP would avoid identified cactus plants by 100 meters. ${ }^{280}$ If plants could not be avoided by 100 meters, additional consultation would be undertaken to develop a site-specific minimization plan, which would then be appended to the 2010 BO.281 One such plan was developed in 2011, with respect to expansion of the Black Hills Homer Deep Unit Well \#21-41 (HDU 21-41), to install two new pipelines and reroute an existing road.282

FWS received a request, from BLM, for informal consultation on HDU 21-41 on May 27, 2011.283 Prior to this, however, there were various communications between FWS and BLM with respect to HDU 21-41. FWS was first contacted about the project, by BLM, on March 17, 2011. In the days following this, staff from the two agencies exchanged a number of emails about the project, before meeting in person on March 24. Discussions between FWS and BLM continued, via phone and email, over the subsequent three months. Throughout this time, agency staff discussed the process for consulting on HDU 21-41, ultimately agreeing that the project is covered by the $2010 \mathrm{BO}$ on the WPMDP, and may be appended thereto.

On May 27, FWS received Black Hills Site Specific Minimization Plan for HDU 21-41 from BLM, triggering the start of consultation. From that date, consultation lasted just twenty-seven days. On June 22, FWS issued a letter concurring with BLM's view that HDU 21-41 "would not

80 | Protecting Species or Endangering Development | August 2016 
significantly change the direct, indirect, or cumulative impact analyzed in the" 2010 BO. ${ }^{284}$ The letter therefore amended the BO to cover HDU 21-41.285

\section{CASE STUDY 5: CROWN ENERGY PARTNERS' DRILLING OF 13 NATURAL GAS WELLS}

In July 2011, BLM consulted with FWS on a project involving the drilling of thirteen natural gas wells in Sweetwater County in southwestern Wyoming by Crown Energy Partners, LLC ("Crown Energy"). ${ }^{286}$ As part of the project, Crown Energy proposed to withdraw up to 78.5 acre-feet of water from the Colorado River Basin, for use in well drilling and completion. ${ }^{287}$ BLM determined that the water withdrawals may adversely affect the four endangered Colorado River Fishes and therefore requested formal consultation with FWS on the project. ${ }^{288}$ Consultation proceeded in a streamlined manner under the RIP.

In a letter dated July 1, 2011, BLM requested that FWS initiate formal consultation with respect to the Crown Energy project. ${ }^{289}$ Prior to receiving the letter on July 5, FWS had not received any information regarding the project, from BLM or Crown Energy. That is, while most formal consultations are preceded by informal discussions between BLM and FWS, no such preconsultation discussions occurred with respect to the Crown Energy project. We understand from agency staff that this fairly typical for projects reviewed under the RIP. Some projects covered by the RIP, particularly those involving large water depletions exceeding 100 acre-feet, are discussed by agency staff at quarterly meetings. Such discussions did not, however, occur on the Crown Energy project.

In its letter requesting formal consultation, BLM provided a basic description of the project, quantified the water depletions associated with the project, and identified the location of those water depletions. Based on this information, FWS conducted a review to confirm that the project was covered by the RIP. This review commenced on July 5, 2011 and proceeded quickly, with FWS issuing its BO just seventeen days later, on July 21, 2011.290 The BO noted that water depletions associated with the project may adversely affect the Endangered Colorado River Fishes. ${ }^{291}$ The BO did not, however, explain the nature of those effects. Rather, it merely

concluded that the RIP "was intended to be the reasonable and prudent alternative to avoid jeopardy to the endangered fish by depletions from the Upper Colorado River." 292

We understand from agency staff that, during review of the project and preparation of the $\mathrm{BO}$, there were no communications between BLM and FWS. ${ }^{293}$ Beyond providing information, in its initial letter dated July 1, BLM was not directly involved in the project review. There was also no involvement by Crown Energy in the project review. BLM staff indicated that, where a project is covered by the RIP, the project proponent is typically not involved in any discussions with FWS. Rather, all dealings with FWS are handled by BLM.

81 | Protecting Species or Endangering Development | August 2016 


\section{CASE STUDY 6: NEWFIELD PRODUCTION'S 20-ACRE INFIELD DEVELOPMENT PROJECT}

The largest project reviewed under the RIP involved a proposal, by Newfield Production ("Newfield"), to drill up to 600 oil wells on public lands in Uintah and Duchesne Counties in north-eastern Utah. ${ }^{294}$ As part of the project, Newfield proposed to use 350 acre-feet of water per year for well drilling and a further 78 acre-feet for dust suppression, for a total of 428 acrefeet per year. ${ }^{295}$ This water was to be sourced from an underground well, tributary to the Green River, in the Upper Colorado River Basin. 296

The Newfield project was one of several permitted under the Federal Permit Streamlining Pilot Program established in 2005 by then-Secretary of the Interior Gale Norton. ${ }^{297}$ The now defunct program aimed to streamline the permitting of oil and gas development on public lands by promoting greater interagency cooperation. To this end, the program designated seven BLM field offices in Colorado, Montana, New Mexico, Utah, and Wyoming as pilot program offices. ${ }^{298}$ These offices housed staff from various agencies involved in reviewing oil and gas projects, including FWS. ${ }^{299}$

The co-location of BLM, FWS, and other agency staff in the same office was intended to facilitate greater information sharing and thereby increase efficiency. There is anecdotal evidence, from agency staff, that it also led to the streamlining of consultations under section 7 of the ESA. According to one staffer interviewed for this study, the sharing of office space enabled BLM and FWS staff to more easily discuss ongoing and planned consultations, leading to a "smoother" process.

Given the above, it is perhaps unsurprising that consultation on the Newfield project proceeded quickly, lasting just thirty-five days. FWS received the request for consultation on October 18, 2011 and issued its BO on November 21, 2011. We understand from with agency staff that there may have been some informal discussions between FWS and BLM prior to the official start of consultation. There are records of various email exchanges between the two agencies beginning on October 6, 2011.

In its BO, FWS determined that RIP "activities will serve as the conservation measures to minimize adverse effects to the ... [Endangered Colorado River Fishes] caused by the project's new depletion." 300 As the project involved annual depletions exceeding 100 acre-feet, Newfield was required to pay a one-off depletion charge of $\$ 8,221.88$, under the RIP. ${ }^{301}$ In addition, Newfield also agreed to implement other conservation measures, including adopting freshwater collection practices that minimize impacts on larval fish, screening all pump intakes to prevent passage of fish into the intake, and reporting any fish impinged on the intake screen to FWS. 302

82 | Protecting Species or Endangering Development | August 2016 


\section{CASE STUDY 7: THREE FORKS RESOURCES' OIL WELL DEVELOPMENTS IN CENTRAL WYOMING}

The sole consultation under the PRRIP related to a project involving the drilling of four oil and gas wells in central Wyoming by Three Forks Resources LLC ("Three Forks"). 303 As part of the project, Three Forks proposed to withdraw 18.2 acre-feet of water from a privately-owned quarry pond located 0.2 miles from the North Platte River. ${ }^{304}$ BLM determined that water withdrawals may adversely affect the Platte River Fish and Bird species and therefore requested formal consultation with FWS. Following the streamlined process established through the PRRIP, FWS produced a tiered $\mathrm{BO}$, which incorporated analysis and findings from the previous PBO. 305

As is standard practice for projects involving water depletions from the Platte River, prior to initiating consultation, BLM requested that Three Forks provide details of the amount and source of the water to be used. This information is then forwarded to the Wyoming State Engineer's Office, which conducts a review to confirm that the use is covered by the State Water Plan, and issues BLM with a letter to this effect. Where such a letter is issued, the water use will be taken to be covered by the PRRIP, and may therefore undergo streamlined consultation.

Agency staff interviewed for this study reported that FWS is typically not involved in discussions between BLM and the State Engineer's Office. According to agency staff, some projects involving large water depletions are discussed, by BLM and FWS, prior to the initiation of consultation at interagency team meetings. Beyond this however, there are generally no preconsultation discussions about the projects. This was true with respect to the Three Forks Resources project.

BLM requested formal consultation on the Three Forks project, by letter to FWS, dated June 2, 2014 and received on June 5. ${ }^{306}$ On the same date, FWS also received a letter from the Wyoming State Engineer's Office, confirming that the project involved an existing water depletion covered by the PRRIP. ${ }^{307}$ FWS therefore determined that the project was eligible for review under the PRRIP and that its BO "regarding the effects of the Project on the [Platte River Fish and Bird] species...can tier from the [PRRIP] PBO." 308 As a result of this tiering, FWS was able to complete its review quickly, issuing its BO on June 19, 2014.

According to agency staff interviewed for this study, prior to issuing its BO, FWS may sometimes have informal discussions with BLM and/or the applicant to clarify details of the project and/or obtain additional information. Such discussions are, however, fairly uncommon and did not occur with respect to the Three Forks project. For this and most other projects covered by the PRRIP, then, consultation tends to be fairly straightforward.

83 | Protecting Species or Endangering Development | August 2016 


\section{CASE STUDY 8: PETROQUEST ENERGY'S OIL DRILLING IN NORTH EASTERN OKLAHOMA}

In October 2012, informal consultation was undertaken between BLM and FWS, to assess the likely effects of oil production by PetroQuest Energy LLC ("PetroQuest"). PetroQuest proposed to drill two wells, known as Shores \#1-4H and Denney \#1-3H, to produce oil from the federal mineral estate. Drilling was proposed to occur on split-estate lands, the surface of which was in private ownership. Nevertheless, as the wells would be drilled through and produce from federally-owned minerals, PetroQuest required an approved APD from BLM.

In reviewing the APD, BLM determined that well drilling by PetroQuest may affect the American Burying Beetle (Nicrophorus americanus) (“ABB”). A large black insect with distinctive orange-red markings, the $\mathrm{ABB}$ is named for its unique behavior of burying carrion, so as to provide nutrition for developing young. The species once inhabited thirty-five states in the eastern and central U.S., but is now found in less than ten percent of its historic range, with extant populations in just six states. As a result of declining population numbers, the FWS listed the $\mathrm{ABB}$ as an endangered species in 1989.

One of the last remaining populations of $\mathrm{ABB}$ is in eastern Oklahoma in an area containing significant oil and gas resources. Where oil and/or gas development is to be permitted by a federal agency, such as BLM, consultation may be required under the ESA. Seeking to increase the efficiency of consultation, FWS's Oklahoma Ecological Services Field Office has developed a number of policies, to guide agencies in assessing the effects of proposed actions on the ABB. Although these policies have been revised in recent years, for the purposes of this case study, we will focus on the policies existing at the time of review of the PetroQuest project.

At the time PetroQuest's project was reviewed by BLM, in 2012, a step-wise process was used to assess the need for consultation on the ABB. This process involved three key stages:

1. BLM first had to determine whether the project will occur within the ABB's range, using FWS's Information, Planning, and Conservation ( $\mathrm{IPaC})$ website.

2. If $\mathrm{IPaC}$ lists the $\mathrm{ABB}$ as a species within the project area, BLM must request an official species list from FWS. Assuming the ABB is included on the list, and if the project will disturb more than 1.2 acres, an evaluation must be conducted to determine whether the project area contains suitable habitat for the $\mathrm{ABB}$.

3. If the project area is found to contain suitable habitat, surveys must be conducted to determine the presence or absence of $\mathrm{ABB}$. The results of that survey determine the type of consultation to be undertaken, with formal consultation required whenever $\mathrm{ABB}$ are found to be present, but only informal consultation required when $\mathrm{ABB}$ are absent.

BLM followed this step-wise process in assessing the PetroQuest project. After IPaC showed that the project area overlapped with $\mathrm{ABB}$ range, BLM obtained an official species list from FWS on October 9,2012. That list confirmed the overlap, necessitating the conduct of a survey, 
to assess the presence or absence of $\mathrm{ABB}$. The survey, which was conducted by industry consultant Reagan Smith Energy Solutions, Inc., found that no ABB were present. BLM therefore concluded that the project was not likely to adversely affect $\mathrm{ABB}$ and consulted with FWS on an informal basis only.

Informal consultation was conducted using the Oklahoma Ecological Services Field Office's online project review process. Under this streamlined process, an action agency may submit information on a project that is not likely to adversely affect listed species to FWS and, if FWS does not notify the agency that additional coordination is necessary within thirty-five days, consultation may be considered complete. BLM submitted information regarding the PetroQuest project to FWS on October 15, 2012. When FWS did not respond within thirty-five days, consultation on the project was taken to be complete on November 19, 2012.

\section{CASE STUDY 9: IVANPAH SOLAR ELECTRIC GENERATING SYSTEM IN SOUTHERN CALIFORNIA}

On June 10, 2011 FWS issued a BO for the Ivanpah Solar Electric Generating System Project in San Bernardino County, California. The Ivanpah project is the largest solar thermal power plant in the world, capable of producing 370 MW of solar energy on 3,582 acres of public land. It was the first utility-scale solar project to begin construction on BLM land. Although BLM permitted two others prior to Ivanpah, the Imperial Valley Solar Project and the Lucerne Valley Solar Project, these projects were terminated by the developer for financing reasons and were never constructed.

In December 2009, BLM initiated consultation with FWS, and on October 1, 2010, FWS issued a $\mathrm{BO}$ analyzing the effects the project would have on the Mojave desert tortoise. FWS determined that the project was not likely to jeopardize the continued existence of the desert tortoise and issued an incidental take statement exempting take of thirty desert tortoises.

Once construction began however, BLM discovered that there was a much higher number of tortoises present in the project area than exempted in FWS's incidental take statement. Consequently, BLM halted the project and BLM and the applicant conducted additional, extensive desert tortoise surveys in the area. On February 28, 2011, BLM requested re-initiation of consultation, and FWS issued a revised BO and incidental take statement on June 10, 2011. The major differences between the 2011 BO and the 2010 BO involved changes to the translocation strategy for the desert tortoises, proposed modifications to desert tortoise handling procedures, and installation of desert tortoise fencing and culverts.

As the first utility-scale solar project to be constructed on public lands, agency and industry representatives we spoke to describe the Ivanpah project as setting the stage for approval of later projects. In part due to the extensive tortoise surveys conducted in the area, FWS gained a greater understanding of the importance of habitat connectivity to the tortoise's recovery, and

85 | Protecting Species or Endangering Development | August 2016 
incorporated this information into consultations on later projects, such as Stateline Solar and Silver State South. Moreover, agency representatives agree that the location of the Ivanpah project would not have been approved today under BLM's new land use guidelines and the DRECP, discussed below.

\section{CASE STUDY 10: STATELINE SOLAR AND SILVER STATE SOUTH PROJECTS IN SOUTHERN CALIFORNIA}

The Stateline Solar and Silver State South projects are two solar projects that FWS requested BLM consolidate into one consultation request. The Stateline project is a proposed 300megawatt solar photovoltaic plant on 1,685 acres of land in San Bernardino County, California. The Silver State South Solar project is 250-megawatt plant on 2,400 acres of land in Clark County, Nevada. FWS initially issued a BO on September 16, 2010, for three phases of the Silver State Solar Project in Nevada proposed by First Solar. BLM then issued a ROW for phase I of the project and incorporated FWS's biological opinion as a term and condition. This portion of the project is referred to as the Silver State (North) Solar Energy Project (see Table 6 above).

On January 2, 2013, BLM requested initiation of formal consultation for the issuance of a ROW for the Stateline Project in California, also proposed by First Solar. On February 11, 2013, BLM requested re-initiation of formal consultation for phases II and III of the Silver State Solar Project, referred to as the Silver State South Project.

On March 4, 2013, FWS requested that BLM consolidate the two consultation requests because of the close proximity of the projects, which were proposed to be located approximately three miles apart across the California and Nevada border in San Bernardino County, California and Cark County, Nevada. Additionally, FWS determined that consolidating the consultations made sense given "the similarity between the effects of the projects, and the need to comprehensively address impacts to habitat and connectivity in the Eastern Mojave Recovery Unit of the desert tortoise." 309

After consolidation of the consultations, FWS, BLM and the applicant engaged in a series of discussions regarding both project layouts to reduce the effects of the proposed actions on the desert tortoise. As a result, First Solar reduced the overall acreage of the Stateline facility in California and shifted the entire project to the east. Furthermore, First Solar moved phase II of the Silver State South facility to the west and removed phase II from the proposed project. On September 30, 2013, FWS issued its BO for the consolidated consultation for the Stateline Solar and Silver State Solar South Projects. BLM approved the projects in February 2014 and construction is supposed to be completed this year.

86 | Protecting Species or Endangering Development | August 2016 


\section{CASE STUDY 11: FOUR SOLAR ENERGY PROJECTS IN THE DRY LAKE SOLAR ENERGY ZONE IN NEVADA}

As discussed above, in 2012 FWS issued a PBO to BLM in response to BLM's proposal to establish a Solar Energy Program and designate SEZs by amending RMPs in Arizona, California, Colorado, Nevada, New Mexico, and Utah. (“Solar PBO”). FWS determined in the Solar PBO that amendment of BLM's RMPs and establishment of SEZs were not likely to jeopardize the continued existence of the desert tortoise.

The Dry Lake SEZ is one of 17 SEZs identified for utility-scale solar energy development. In June 2014, BLM held a competitive leasing auction for six parcels in the Dry Lake SEZ in Nevada on approximately 3,000 acres of land.

On May 1, 2015, FWS issued four BOs for four proposed solar projects located in the Dry Lake SEZ related to the desert tortoise ("Dry Lake BO's"). ${ }^{310}$ The Dry Lake BO's are the first set of $\mathrm{BOs}$ that are tiered to the Solar PBO. Three of the four formal consultations are tiered to the Solar PBO. The fourth project did not meet the minimum size requirement for a SEZ project and consequently, was not tiered to the Solar PBO. One consultation (relating to the Playa Solar Project) was tiered to a second PBO for the Muddy River Memorandum of Agreement to address effects that groundwater withdrawals related to the project would have on the Moapa dace (Moapa coriacea), and endangered fish under the ESA.

The Dry Lake BO's include conservation measures that are applicable to all of the projects. Many of these measures are based on measures in the Solar PBO, but the Dry Lake BO's contain project-specific effects that are not included in the Solar PBO. For all four projects, FWS concluded that the proposed actions were not likely to jeopardize the continued existence of the desert tortoise, and in the case of the Playa Solar Project the Moapa dace as well.

In addition to minimizing the impact solar energy development has on desert ecosystems, the intent of BLM's Solar Energy Program and FWS's Solar PBO was to streamline the permitting and consultation process for solar energy projects built within designated SEZ's. As the Dry Lake SEZ is the first SEZ BLM has opened for leasing, agency and industry representatives we spoke to remarked that it is still too early to tell whether the programmatic approach to approval of solar energy projects is achieving the intended efficiency.

\section{CASE STUDY 12: TULE WIND PROJECT IN SOUTHERN CALIFORNIA}

The Tule Wind project is a 186 MW wind energy facility in southern California. ${ }^{311}$ The project, proposed by Tule Wind, LLC ("TW"), involved construction of 128 wind turbines, three meteorological towers, overhead transmission lines, substation facilities, and associated infrastructure on approximately 725 acres of land in south-eastern San Diego County. ${ }^{312}$ The construction area included 536 acres of public land and 80 acres of tribal land, use of which required approval from the BLM and Bureau of Indian Affairs ("BIA") respectively.313

87| Protecting Species or Endangering Development | August 2016 
BLM was designated as the lead agency, and BIA as a co-operating agency, for reviewing the Tule Wind Project. In the course of its review, BLM determined that the project would involve construction in or near habitat occupied by the Quino checkerspot butterfly (Euphydryas editha quino). Listed as an endangered species in 1997, the Quino checkerspot is a medium-sized butterfly, with brown, red, and yellow spotted wings. It is native to the U.S. and Mexico, historically inhabiting large areas of coastal scrub land in southern California and northern Baja California. Land clearing in these areas has led to a substantial decline in Quino checkerspot numbers. It is now limited to a few small populations, inhabiting Riverside and San Diego Counties, including the proposed site of the Tule Wind Project.

On September 7, 2010, BLM requested that FWS initiate formal consultation to assess the likely effects of construction and operation of the Tule Wind Project on the Quino checkerspot butterfly. This was not, however, the first time FWS had been contacted about the Tule Wind Project. Almost ten months earlier, on December 10, 2009, FWS had received a request for a species list for the project. The requested list was provided to BLM on February 1, 2010 and indicated that Quino checkerspot may be present in the project area. Independent consultants HDR, Engineering, Inc. were subsequently hired to survey the area, and identified a small number of adult Quino checkerspot, as well as various plants capable of supporting the butterfly during its larval stage.

In July 2010, HDR, Engineering, Inc. prepared a draft BA on the likely effect of the Tule Wind project on the Quino checkerspot for BLM. BLM forwarded the BA, along with a request for formal consultation, to FWS in September 2010. From that time, it took almost one year for FWS to complete its review, and issue a $\mathrm{BO}$ on the Tule Wind Project. We understand from discussions with agency staff that the delay in issuing a BO was likely due to the heavy workload of FWS staff.

After submission of the BA in September 2010, FWS continued to receive additional information regarding the Tule Wind project until June 2011. Based on that information, FWS prepared a draft BO, which was provided to BLM, for review and comment on June 29. BLM forwarded a copy of the draft to Tule Wind, LLC and other interested parties. On August 5, comments from all interested parties were received by FWS, which then amended the BO, and issued a revised draft on August 29. After no further comments were received, FWS finalized the $\mathrm{BO}$, and issued it to BLM on September 2.

In the BO, FWS concluded that the Tule Wind project would not jeopardize the continued existence of the Quino checkerspot butterfly. ${ }^{314}$ This conclusion was based on the adoption, by $\mathrm{TW}$, of various "measures to minimize direct mortality of Quino eggs, larvae, pupae, and adults and to avoid ... indirect effects," including due to habitat loss. ${ }^{315}$ Among other things, TW agreed to compensate for any permanent habitat loss (at a ratio of two to one) through land acquisition and perpetual management, only undertake certain construction activities outside of

88 | Protecting Species or Endangering Development | August 2016 
the butterfly flight season, avoid construction in occupied habitat where butterflies or their host plants have been observed, take steps to minimize the creation of dust clouds during construction, restrict vehicle traffic and speeds within the construction area, and develop a weed management plan to prevent and treat weed infestations. 316

\section{CASE STUDY 13: GRAHAM PASS WIND PROJECT IN CALIFORNIA}

The Graham Pass wind project is a proposed utility-scale commercial wind development project in Riverside County, California within the Mojave desert tortoise Colorado Desert Recovery Unit, which includes the designated Chuckwalla critical habitat unit and BLM designated Chuckwalla Desert Wildlife Management Area ("DWMA") / Area of Critical Environmental Concern ("ACEC"). 317 The project is divided into three phases. The first phase includes installation of two temporary meteorological towers for wind monitoring and testing, as well as bird and bat acoustic studies, necessary to determine the suitability of the site for phases two and three of the project, involving construction of a 30,800 acre wind farm. ${ }^{318}$

On July 13, 2011, BLM contacted the Palm Springs office of FWS requesting concurrence with its determination that phase one of the project was not likely to adversely affect the threatened Mojave desert tortoise. On November 28, 2011, FWS issued its concurrence letter. ${ }^{319}$ FWS determined that, based on implementation of the avoidance and minimization measures, phase one of the project would not result in adverse impacts to desert tortoises. ${ }^{320}$ The avoidance and minimization measures incorporated into phase one included, among other things, hiring a qualified biologist to conduct desert tortoise surveys, keeping disturbed areas confined to the smallest practical area, flagging desert tortoise habitat features, limiting vehicular traffic to roads, limiting vehicle speeds within the project area to 20 miles per hour, and erecting structures in a manner so as to discourage ravens from nesting or perching. ${ }^{321}$ Furthermore, BLM incorporated additional mitigation measures into phase one of the project design to protect migratory birds. ${ }^{322}$

Interestingly, although FWS concurred that phase one of the project would not result in adverse impacts to the desert tortoise, FWS stated, "we are concerned about the potential future impacts that would occur" from construction of phase two and three of the project. ${ }^{323}$ FWS explained that BLM is evaluating a large number of wind development projects within the boundaries of the DWMAs / ACECs, which encompass designated critical habitat for the Mojave desert tortoise, and which FWS anticipates will result in numerous direct and indirect effects to desert tortoise and their habitat within DWMAs. ${ }^{324}$ FWS expressed concern that, "[i]n aggregate, these effects have the potential to reduce the capacity of DWMA's to support recovery of the desert tortoise." 325 Despite its concurrence, FWS recommended that "BLM reconsider issuing a Type I ROW grant pending further discussions and research regarding the compatibility of industrialscale wind energy and development with the function and value of desert tortoise critical habitat and Graham Pass area and desert tortoise conservation." 326

89 | Protecting Species or Endangering Development | August 2016 
From discussions with FWS, it is our understanding that the Graham Pass project has not advanced past phase one and that several other proposed wind developments in the vicinity have been abandoned as project developers await final approval of the DRECP (discussed in Case Study 15 above). 


\section{Appendix 2: Species Involved in Energy Project Consultations}

\begin{tabular}{|c|c|c|}
\hline Species (Common Name) & Scientific Name & Status \\
\hline Amargosa niterwort & Nitrophila mohavensis & Endangered \\
\hline American burying beetle & Nicrophorus americanus & Endangered \\
\hline Arkansas River shiner & Notropis girardi & Threatened \\
\hline Arroyo toad & Anaxyrus californicus & Endangered \\
\hline Ash Meadows Amargosa pupfish & Cyprinodon nevadensis mionectes & Endangered \\
\hline Ash Meadows blazingstar & Mentzelia leucophylla & Threatened \\
\hline Ash Meadows gumplant & Grindelia fraxinipratensis & Threatened \\
\hline Ash Meadows ivesia & Ivesia kingii var. eremica & Threatened \\
\hline Ash Meadows milk-vetch & Astragalus phoenix & Threatened \\
\hline Ash Meadows naucorid & Ambrysus amargosus & Threatened \\
\hline Ash Meadows Speckled dace & Rhinichthys osculus nevadensis & Endangered \\
\hline Ash Meadows sunray & Enceliopsis nudicaulis var. corrugata & Threatened \\
\hline Bakersfield cactus & Opuntia treleasei & Endangered \\
\hline Bald eagle & Haliaeetus leucocephalus & Delisted (2011) \\
\hline Barneby reed-mustard & Schoenocrambe barnebyi & Endangered \\
\hline Barneby ridge-cress & Lepidium barnebyanum & Endangered \\
\hline Black-footed ferret & Mustela nigripes & Endangered \\
\hline Blowout penstemon & Penstemon haydenii & Endangered \\
\hline Blunt-nosed leopard lizard & Gambelia silus & Endangered \\
\hline Bonytail chub & Gila elegans & Endangered \\
\hline California condor & Gymnogyps californianus & Endangered \\
\hline Canada Lynx & Lynx canadensis & Threatened \\
\hline Clay reed-mustard & Schoenocrambe argillacea & Threatened \\
\hline Coachella Valley fringe-toed lizard & Uma inornata & Threatened \\
\hline
\end{tabular}




\begin{tabular}{|c|c|c|}
\hline Species (Common Name) & Scientific Name & Status \\
\hline Coachella Valley milk-vetch & Astragalus lentiginosus var. coachellae & Endangered \\
\hline Coastal California gnatcatcher & Polioptila californica californica & Threatened \\
\hline Colorado Butterfly plant & Gaura neomexicana var. coloradensis & Threatened \\
\hline Colorado hookless Cactus & Sclerocactus glaucus & Threatened \\
\hline Colorado pikeminnow & Ptychocheilus lucius & Endangered \\
\hline Colorado River Cutthroat trout & Oncorhynchus clarkia pleuriticus & Not listed \\
\hline Dakota Skipper & Hesperia dacotae & Threatened \\
\hline DeBeque phacelia & Phacelia submutica & Threatened \\
\hline Desert pupfish & Cyprinodon macularius & Endangered \\
\hline Desert tortoise & Gopherus agassizii & Threatened \\
\hline Devils Hole pupfish & Cyprinodon diabolis & Endangered \\
\hline Dudley Bluffs bladderpod & Lesquerella congesta & Threatened \\
\hline Dudley Bluffs twinpod & Physaria obcordata & Threatened \\
\hline Dunes sagebrush lizard & Sceloporus arenicolus & Not listed \\
\hline Flat-tailed horned lizard & Phrynosoma mcallii & Not listed \\
\hline Giant kangaroo rat & Dipodomys ingens & Endangered \\
\hline Golden eagle & Aquila chrysaetos & Not listed \\
\hline Golden orb & Quadrula aurea & Candidate \\
\hline Graham beardtongue & Penstemon grahamii & Not listed \\
\hline Gray wolf & Canis lupus & Endangered \\
\hline Greater sage-grouse & Centrocercus urophasianus & Not listed \\
\hline Greenback Cutthroat trout & Oncorhynchus clarki stomias & Threatened \\
\hline Grizzly bear & Ursus arctos horribilis & Threatened \\
\hline Gulf Coast jaguarondi & $\begin{array}{l}\text { Herpailurus (=Felis) yagouaroundi } \\
\text { cacomitli }\end{array}$ & Endangered \\
\hline Gunnison sage-grouse & Centrocercus minimus & Threatened \\
\hline Gypsum wild-buckwheat & Eriogonum gypsophilum & Threatened \\
\hline
\end{tabular}




\begin{tabular}{|c|c|c|}
\hline Species (Common Name) & Scientific Name & Status \\
\hline Hiko White River springfish & Crenichthys baileyi grandis & Endangered \\
\hline Horseshoe milk-vetch & Astragalus equisolensis & Not listed \\
\hline Humpback chub & Gila cypha & Endangered \\
\hline Indiana bat & Myotis sodalis & Endangered \\
\hline Jones Cycladenia & Cycladenia humilis var. jonesii & Threatened \\
\hline Last Chance townsendia & Townsendia aprica & Threatened \\
\hline Least Bell's vireo & Vireo bellii pusillus & Endangered \\
\hline Least tern & Sterna antillarum & Endangered \\
\hline Lesser long-nosed bat & Leptonycteris curasoae yerbabuenae & Endangered \\
\hline Lesser prairie-chicken & Tympanuchus pallidicinctus & Threatened \\
\hline Mexican Spotted Owl & Strix occidentalis lucida & Threatened \\
\hline Moapa dace & Moapa coriacea & Endangered \\
\hline Mountain plover & Charadrius montanus & Not listed \\
\hline Nevin's barberry & Berberis nevinii & Endangered \\
\hline North American wolverine & Gulo gulo luscus & Not listed \\
\hline Northern aplomado falcon & Falco femoralis septentrionalis & Endangered \\
\hline Ocelot & Leopardus (=Felis) pardalis & Endangered \\
\hline Pahranagat roundtail chub & Gila robusta jordani & Endangered \\
\hline Pahrump poolfish & Empetrichthys latos & Endangered \\
\hline Pallid sturgeon & Scaphirhynchus albus & Endangered \\
\hline Parachute beardtongue & Penstemon debilis & Threatened \\
\hline Pariette cactus & Sclerocactus brevispinus & Threatened \\
\hline Peninsular bighorn sheep & Ovis canadensis nelsoni & Endangered \\
\hline Piping Plover & Charadrius melodus & Threatened \\
\hline Preble's meadow jumping mouse & Zapus hudsonius preblei & Threatened \\
\hline Quino checkerspot butterfly & Euphydryas editha quino (=E. e. wrighti) & Threatened \\
\hline Razorback sucker & Xyrauchen texanus & Endangered \\
\hline
\end{tabular}




\begin{tabular}{|c|c|c|}
\hline Species (Common Name) & Scientific Name & Status \\
\hline Red-crowned parrot & Amazona viridigenalis & Candidate \\
\hline $\begin{array}{l}\text { San Bernardino Merriam's } \\
\text { kangaroo rat }\end{array}$ & Dipodomys merriami parvus & Endangered \\
\hline San Joaquin kit fox & Vulpes macrotis mutica & Endangered \\
\hline San Rafael cactus & Pediocactus despainii & Endangered \\
\hline Santa Ana River woolly-star & Eriastrum densifolium ssp. sanctorum & Endangered \\
\hline Scaleshell mussel & Leptodea leptodon & Endangered \\
\hline Shrubby reed-mustard & Schoenocrambe suffrutescens & Endangered \\
\hline Slender-horned spineflower & Dodecahema leptoceras & Endangered \\
\hline Slickspot peppergrass & Lepidium papilliferum & $\begin{array}{l}\text { Proposed } \\
\text { endangered }\end{array}$ \\
\hline Southwestern willow flycatcher & Empidonax traillii extimus & Endangered \\
\hline Sprague's pipit & Anthus spragueii & Not listed \\
\hline Spring-loving centaury & Centaurium namophilum & Threatened \\
\hline Star cactus & Astrophytum asterias & Endangered \\
\hline Texas ayenia & Ayenia limitaris & Endangered \\
\hline Tipton kangaroo rat & Dipodomys nitratoides nitratoides & Endangered \\
\hline Uinta Basin hookless cactus & Sclerocactus wetlandicus & Threatened \\
\hline Utah prairie dog & Cynomys parvidens & Threatened \\
\hline Ute ladies'-tresses & Spiranthes diluvialis & Threatened \\
\hline Walker's manioc & Manihot walkerae & Endangered \\
\hline Warm Springs pupfish & Cyprinodon nevadensis pectoralis & Endangered \\
\hline Western burrowing owl & Athene cunicularia hypugea & Not listed \\
\hline Western prairie fringed Orchid & Platanthera praeclara & Threatened \\
\hline White River beardtongue & Penstemon scariosus albifluvis & Not listed \\
\hline White River springfish & Crenichthys baileyi baileyi & Endangered \\
\hline White-faced ibis & Plegadis chihi & Not listed \\
\hline White-tailed prairie dog & Cynomys leucurus & Not listed \\
\hline
\end{tabular}




\begin{tabular}{|l|l|l|}
\hline Species (Common Name) & Scientific Name & Status \\
\hline Whitebark pine & Pinus albicaulis & Candidate \\
\hline Whooping crane & Grus americana & Endangered \\
\hline Winged Mapleleaf & Quadrula fragosa & Endangered \\
\hline Winkler cactus & Pediocactus winkleri & Threatened \\
\hline Wright fishhook cactus & Sclerocactus wrightiae & Endangered \\
\hline Wyoming Toad & Anaxyrus baxteri & Endangered \\
\hline Yellow-billed Cuckoo & Coccyzus americanus & Threatened \\
\hline Yuma clapper rail & Rallus longirostris yumanensis & Endangered \\
\hline
\end{tabular}


- Endnotes -

1 16 U.S.C. $\int 1531$ et seq.

${ }^{2}$ Id. $\int 1531(\mathrm{a})(1)-(2)$.

${ }^{3}$ Id. $\int 1531(\mathrm{~b})$.

${ }^{4}$ U.S. Fish and Wildlife Service, Species Report, ECOS EnVIRONMENTAL CONSERVATION OnLInE System, http://ecos.fws.gov/tess public/pub/adHocSpeciesCountForm.jsp (select "Endangered (E)" and

“Threatened (T) under "Federal Listing Status” and enter 12/31/1973 under "Maximum Date Species First Listed”) (last visited Feb. 27, 2016).

${ }^{5}$ U.S. Fish and Wildlife Service, Listed Species Summary (Boxscore), ECOS ENVIRONMENTAL CONSERVATION ONLINE SYSTEM, http://ecos.fws.gov/tess public/reports/box-score-report (last visited Feb. 26, 2016)

6119 Cong. Rec. 30,167 - 30,168 (1973).

${ }^{7}$ Id. at 25,694 .

${ }^{8}$ See, for example, Kathleen Hartnett White, Texas Public Policy Foundation Center For ENERGy AND THE ENVIRONMENT, THE ENDANGERED SPECIES ACT AND TEXAS: A LOOK AHEAD (2015), available at https://docs.google.com/viewerng/viewer?url=http://old.texaspolicy.com/sites/default/ files/documents/2015-01-PP02-EndangeredSpeciesAct-CEE-KathleenWhite.pdf.

9 Jamie Pang and NoAh Greenwald, Center for Biological Diversity, Politics of Extinction: THE UnPRECEDENTED ATTACK ON ENDANGERED SPECIES AND THE ENDANGERED SPECIES ACT (2015), available at http://www.biologicaldiversity.org/campaigns/esa attacks/pdfs/Politics of Extinction.pdf.

1016 U.S.C. $\int 1536(a)(2)$.

${ }^{11}$ Federal agencies must consult with FWS on any proposed action that may affect listed terrestrial and freshwater species.

${ }^{12}$ Federal agencies must consult with NMFS on any proposed action that may affect listed marine species.

13 See, for example, HOLLAND \& HART, LLP, SUGGESTIONS ON HOW TO IMPROVE THE ENDANGERED SPECIES ACT: PREPARED FOR THE INGAA FOUNDATION, INC. (2007), available at http://www.ingaa.org/File.aspx?id=5691 (reporting the results of a survey of natural gas pipelines, wherein respondents reported that consultation "delay[s] development projects and increases costs, while doing little to protect species and their habitat”).

96 | Protecting Species or Endangering Development | August 2016 


\section{- Endnotes Continued -}

${ }^{14} \mathrm{Jacob}$ W. Malcom and Ya-Wei Li, Data Contradict Common Perceptions About a Controversial Provision of the US Endangered Species Act, 112 Proceedings of the National ACADEMY OF SCIENCE 15844, 15844 - 15849 (2015).

${ }^{15} \mathrm{Id}$.

${ }^{16}$ The authors did note that "[s]ome agencies are proposing projects with reduced impacts because they are coordinating more closely with FWS to shape the projects well before consultations begin." See $I d$. at 15847 .

${ }^{17}$ Western Energy Alliance, Endangered Species Act (ESA), WILDLIFE, http://www.westernenergyalliance.org/ knowledge-center/wildlife/endangered-species-act-esa (last visited Feb. 25, 2016).

1816 U.S.C. $\$ 1531$ (b).

${ }^{19}$ Id. $\$ 1532(6),(20)$.

${ }^{20} I d . \S 1533(\mathrm{a})(1)(\mathrm{A}-\mathrm{E})$.

${ }^{21}$ Tenn. Valley Auth. v. Hill, 437 U.S. 153 (1978).

2216 U.S.C. $\$ 1536(\mathrm{a})(2)$.

${ }^{23} \mathrm{Id}$. $\ 1538(\mathrm{a})(1)(\mathrm{B})-(\mathrm{C})$. See also $\ 1532(19)$.

2450 CFR $₫ 402.12(a)$.

${ }^{25} \mathrm{Id} . \S 402 \cdot 12(\mathrm{i})$.

${ }^{26} I d . \$ 402 \cdot 12(\mathrm{j})$.

${ }^{27} I d . \$ 402 \cdot 13(\mathrm{a})$.

${ }^{28}$ Id. $\$ 402 \cdot 13(\mathrm{a})$.

${ }^{29} I d . \$ 402 \cdot 12(\mathrm{j})$.

${ }^{30}$ These non-federal activities may include state, tribal, local, or private activities that are reasonably certain to occur in the project area.

3150 CFR $₫ 402.14(\mathrm{~h})(3)$. See also $₫ 402.14(\mathrm{~g})(5)$.

${ }^{32} I d . \rrbracket 402 \cdot 14(\mathrm{j})$. See also $\ 402.14(\mathrm{~g})(6)$.

3350 CFR $₫ 402.14(\mathrm{~g})(7)$, (i).

34 16 U.S.C. SS $1538,1539$.

3550 CFR $₫ 402.14(i)(1)$. 


\section{- Endnotes Continued -}

${ }^{36}$ Id. $\int 402.14(\mathrm{i})(2)$. FWS has acknowledged that, while reasonable and prudent measures are intended to minimize the level of incidental take, "Congress also intended that the action go forward essentially as planned" and, as such, "[s]ubstantial design and routing changes . . . are inappropriate in the context of incidental take statements because the action already complies with Section 7(a)(2)" by avoiding jeopardy. See Interagency Cooperation- Endangered Species Act of 1973, as Amended, 51 Fed. Reg. 19926, 19937 (Jun. 3, 1986).

${ }^{37}$ FWS must discuss, with the action agency and any applicant, its basis for any finding in the BO. FWS must, if requested, make available to the action agency its draft BO. See 50 CFR $\int 402.14(\mathrm{~g})(5)$.

${ }^{38} I d$.

${ }^{39} I d$.

40 U.S. General Accounting OfFice, More Federal Management AtTention Needed to Improve THE CONSUltation PROCESs 57 (2004), available at http://www.gao.gov/assets/250/241766.pdf.

41 This is often described as the "batched" programmatic consultation approach. Under this approach, the action agency groups or "batches" a series of proposed projects into one proposed action. FWS produces a single concurrence letter or $\mathrm{BO}$ assessing the effects of all of the projects.

${ }^{42} I d$.

${ }^{43}$ U.S. General Accounting Office, supra note 40, at 25.

44 U.S. DePARTMENT OF THE INTERIOR Fish AND WildlifE SERVICE, SECTION 7 CONSUltation, Sufficient Progress, And Historic Projects Agreement And RECOVERy ACtion Plan 3 (1993), available at http://www.coloradoriverrecovery.org/documents-publications/foundationaldocuments/RIPRAP/15Oct1993RIPRAP.pdf.

45 Memorandum from Field Supervisor, Ecological Services Sacramento Field Office, Fish and Wildlife Service, to Caliente Resource Area Manager, Bureau of Land Management (Jul. 17, 1996) (on file with authors); Memorandum from Assistant Field Supervisor, Sacramento Fish and Wildlife Office, to Manager, Bureau of Land Management (Sep. 28, 2001) (on file with authors).

46 Memorandum from Regional Director, Region 6, Fish and Wildlife Service, to Geographic Assistant Regional Director, Southern Geographical Area, Region 6 (Dec. 1999) (on file with authors); Memorandum from Regional Director, Region 6, Fish and Wildlife Service, to Assistant Regional Director, Ecological Services, Region 6 (Jan. 10, 2005) (on file with authors); Memorandum from Colorado Field Supervisor, Ecological Services, Fish and Wildlife Service, to Area Manager, Western Colorado Area Office, Bureau of Reclamation (Dec. 4, 2009) (on file with authors). 


\section{- Endnotes Continued -}

${ }^{47}$ Memorandum from Steve Anschutz, Field Supervisor, Nebraska Ecological Services Field Office, U.S. Fish and Wildlife Service, to Michael J. Ryan, Regional Director, Great Plains Region, Bureau of Reclamation and Mike Stempel, Assistant Regional Director, Fisheries and Ecological Services, Region 6, U.S. Fish and Wildlife Service (Jun. 16, 2006) (on file with authors).

${ }^{48}$ Letter from Richard E. Sayers, Chief, Division of Consultation, Habitat Conservation Planning, Recovery, and State Grants, U.S. Fish and Wildlife Service to Kathleen Clarke, Director, Bureau of Land Management (Nov. 30, 2005) (on file with authors).

${ }^{49}$ U.S. Department of the Interior Fish and Wildlife SERVICE, ENDANGERED SPECIES ACt CONSUltation FOr SOlAR ENERgy PROgRAm (2012), available at http://solareis.anl.gov/documents/docs/SolarPEIS Biological Opinion.pdf.

${ }^{50}$ National Environmental Policy Act, \102(2)(C); 42 U.S.C. \ 4332(2)(C).

5140 CFR $\$ 1508.9$. See also $\$ \int 1501.3,1501.4$.

${ }^{52}$ National Environmental Policy Act, \102(2)(C); 42 U.S.C. \4332(2)(C). See also 40 CFR Part 1502.

${ }^{53}$ U.S. Fish and Wildlife Species, What's the difference between an Environmental Assessment and a Biological Assessment, and can I incorporate one into the other? CONSULTATIONS: FREQUENTLY ASKED QUESTIONS, , http://www.fws.gov/endangered/what-we-do/faq.html\#9 (last updated Jul. 15, 2013)

${ }^{54}$ U.S Fish and Wildlife Service \& National Marine Fisheries Service, Endangered Species Consultation Handbook: Procedures for Conducting Consultation and Conference Activities Under Section 7 of the Endangered Species Act 4-11 (1998), available at https://www.fws.gov/ENDANGERED/esalibrary/pdf/esa section7 handbook.pdf

${ }^{55} \mathrm{Id}$.

${ }^{56} \mathrm{Id}$.

${ }^{57}$ U.S. Department of the Interior Bureau of Land Management, The Bureau of Land Management: Who We Are, What We Do, ABOUT THE BLM, http://www.blm.gov/wo/st/en/info/About BLM.html (last updated Jan. 26, 2012).

5843 U.S.C. S\$1701 et seq.

${ }^{59}$ Id. $\int \mathbb{S} 1701(\mathrm{a})(7), 1702(\mathrm{c})$

${ }^{60} I d$.

${ }^{61}$ Some older land use plans are known as Management Framework Plans. 


\section{- Endnotes Continued -}

62 Bureau of Land Management, Land Use Planning, DeCision SupPORT, PLANNING, \& NEPA, http://www.blm.gov/wo/st/en/prog/planning/planning overview.html (last updated Dec. 16, 2015).

${ }^{63} I d$.

${ }^{64}$ U.S. Geological Survey, Federal Lands and Indian Reservations, http://nationalmap.gov/small scale/printable/fedlands.html (last visited Jul. 13, 2016).

${ }^{65} \mathrm{Id}$. (revision of a plan involves "a complete or near complete re-write of an existing" resource management plan. Plan amendment involves "a modification of one or more parts (for example, decisions about livestock grazing) of an existing" resource management plan).

${ }_{66}$ Memorandum of Agreement on Endangered Species Act Section 7 Programmatic Consultations and Coordination, Between Bureau of Land Management, Forest Service, National Marine Fisheries Service, and Fish and Wildlife Service, Aug. 30, 2000, available at http://www.blm.gov/or/esa/reports/Procedures/Interagency MOA for Plan and Programmatic Consultat ion.doc [hereinafter MOA on Programmatic Consultations].

${ }^{67} I d$.

${ }^{68} I d$.

${ }^{69} I d$.

${ }^{70} I d$.

${ }^{71}$ U.S. DEPARTMENT OF THE INTERIOR, AMERICAN ENERGY FOR AMERICA'S FUTURE: THE ROLE OF THE U.S. DEPARTMENT OF INTERIOR 3 (2004), available at http://www.blm.gov/style/medialib/blm/wo/MINERALS REALTY AND RESOURCE PROTECTION .Par.61407.File.dat/EnergyBro.pdf.

72 U.S. Department of the Interior and U.S. Department of Agriculture, New Energy Frontier: Balancing Energy Development on Federal Lands 14, 17 (2011), available at https://www.doi.gov/sites/doi.gov/files/migrated/whatwedo/energy/upload/NewEnergyFrontier050511.pdf

${ }^{73}$ U.S. Department of the Interior, supra note $71,4$.

7443 CFR JS 2801.2-2809.10 (governing issuance of ROWs under FLPMA); 43 CFR \ 3101 et seq. (governing issuance of permits under the Mineral Leasing Act).

7543 U.S.C. $\int 1761$ (2016).

7630 U.S.C \ 185 (2016). 


\section{- Endnotes Continued -}

7730 U.S.C. $\$ 223$.

${ }^{78}$ U.S. Department of the Interior Bureau of Land Management, Land Use Planning, LEASING OF ONSHORE FEDERAL OIL AND GAS RESOURCES, http://www.blm.gov/wo/st/en/prog/energy/oil and gas/ leasing of onshore/og planning.html (last updated Oct. 20, 2009).

${ }^{79}$ U.S. Department of the Interior Bureau of Land Management, Competitive LEASING, LEASING OF ONSHORE FEDERAL OIL AND GAS RESOURCES, http://www.blm.gov/wo/st/en/prog/energy/oil and gas/ leasing of onshore/og leasing.html (last updated Oct. 20, 2009).

${ }^{80} \mathrm{Id}$.

${ }^{81}$ Lease stipulations are developed by BLM, on an ad hoc basis, outside of the formal planning process. We understand from discussions with agency staff that FWS is typically not involved in the development of lease stipulations. Those stipulations are, however, incorporated into RMPs as they are revised and will be reviewed by FWS when it consults on the revised RMP.

82 Unlike in New Mexico, in Utah, lease stipulations are not developed on an ad hoc basis, but rather during the formal planning process, when an RMP is issued or amended. As part of the consultation on the RMP, BLM and FWS agree on lease stipulations, required to protect listed species

${ }^{83} I d$.

${ }^{84}$ U.S. Department of the Interior Bureau of Land Management, New Energy for America, RENEWABLE ENERGY RESOURCES, http://www.blm.gov/wo/st/en/prog/energy/renewable energy.html (last updated Jul. 1, 2015).

${ }^{85}$ U.S. Department of the Interior Bureau of Land Management, Final Programmatic

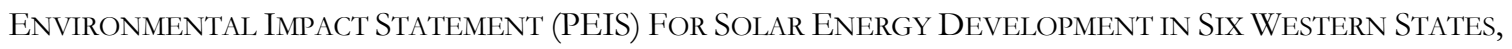
FES 12-24 (2005), available at http://solareis.anl.gov/documents/fpeis/Solar FPEIS ExecutiveSummary.pdf; See also Bureau of Land Management Solar Energy Program, Western Solar Plan, SOLAR ENERGy Program, http://blmsolar.anl.gov (last visited Mar. 10, 2016).

${ }^{86}$ Solar Energy Development Programmatic EIS Information Center, Solar Energy Zones, http://solareis.anl.gov/sez/index.cfm (last visited Mar. 10, 2016).

87 U.S. DePartMeNt OF THE INTERIOR Fish AND Wildlife SERVICE, ENDANGERED SPECIES ACt CONSUltation For SOlAR ENERgy PROgRAm 1 (2012), available at http://solareis.anl.gov/documents/docs/SolarPEIS Biological Opinion.pdf. ${ }^{88} I d$. 


\section{- Endnotes Continued -}

${ }^{89}$ U.S. Department of the Interior Bureau of Land Management, Record of Decision: Implementation of a Wind Energy Development Program and Associated Land Use Plan Amendments (2005), available at http://windeis.anl.gov/documents/docs/WindPEISROD.pdf.

90 The nine states are Colorado, Idaho, Montana, Nevada, New Mexico, Oregon, Utah, Washington, and Wyoming. See Id. at B-2.

${ }^{91}$ U.S. DEPARTMENT OF THE INTERIOR BUREAU OF LAND MANAGEMENT, INSTRUCTION MEMORANDUM NO. 2009-043: Wind EnERgy DeVElopment Program Attachment 1 (2008), available at http://www.blm.gov/wo/st/en/info/regulations/Instruction Memos and Bulletins/national instruction/20 09/IM 2009-043.html. .

92 FWS found that the following species may be adversely affect: the bald eagle (Haliaeetus leucocephalus), Mojave desert tortoise (Gopherus agassizii ), grizzly bear (Ursus arctos horribilis), least tern (Sternula antillarum), Mexican spotted owl (Strix occidentalis lucida), northern aplomado falcon (Falco femoralis septentrionalis), piping plover (Charadrius melodus), southern willow flycatcher (Empidonaz traillii extimus), and whooping crane (Grus americana).

${ }^{93}$ Letter from Richard E. Sayers, Chief, Division of Consultation, Habitat Conservation Planning, Recovery, and State Grants, U.S. Fish and Wildlife Service to Kathleen Clarke, Director, Bureau of Land Management (Nov. 30, 2005) (on file with authors).

${ }^{94}$ U.S. Department of the Interior, supra note 89, at A-5 - A-20.

95 U.S. Department of the Interior, supra note 91, at Attachment 1.

${ }^{96} I d$.

${ }^{97}$ U.S. FiSH AND WILDLIFE SERVICE, LAND-BASED WIND ENERGY GUIDELINES (2012), available at https://www.fws.gov/ecological-services/es-library/pdfs/WEG final.pdf.

${ }^{98} I d$. at vi.

${ }^{99}$ A group of 15 wind energy companies, in coordination with FWS and nine state wildlife agencies, are also developing a programmatic habitat conservation plan (HCP) - the Great Plains Wind Energy HCP - to address the potential impacts of wind energy development on the whooping crane, interior least tern, piping plover, and lesser-prairie chicken. For more information about the Great Plains Wind Energy HCP, see WIND EnERgy WhoOping Crane ACtion Group, Great Plains Wind EnERgy Habitat CONSERVATION Plan (2013), available at http://www.greatplainswindhcp.org/documents/fact sheet.pdf.

${ }^{100}$ U.S. Fish and Wildlife Service, supra note 97, at vii. 


\section{- Endnotes Continued -}

${ }^{101}$ U.S. Environmental Protection Agency, EPA Office of Compliance Sector Notebook Project: Profile of the Oil and Gas Extraction Industry 15 (2000), available at http://archive.epa.gov/sectors/web/pdf/oilgas.pdf.

$102 I d$.

${ }^{103} I d$.

${ }^{104} I d$.

${ }^{105} \mathrm{Id}$.

106 North Dakota GAme and Fish, Potential Impacts of OIL AND Gas DeVElopment on SELECT NORTH DAKOTA NATURAL ReSOURCES (2011), available at http://gf.nd.gov/sites/default/files/publications/ specialty-publications/directors-report-oil-gas-may-2011.pdf.

${ }^{107}$ Id. See also Rachel Jankowitz, NeW Mexico Department of Game and Fish, Oil and Gas Development Guidelines: Conserving New Mexico’s Wildlife Habitat and WildLife 19 (2007), available at http://www.wildlife.state.nm.us/download/conservation/habitat-handbook/Oil-and-gasdevelelopment-guidelines.pdf.

108 National Renewable Energy Laboratory, Utility-SCAle ConCENTRATing Solar Power AND Photovoltaics Projects: A TECHNOLOGY AND MARKET OVERVIEW (2012), available at http://www.nrel.gov/docs/fy12osti/51137.pdf.

109 Solar Energy Industry Association, Photovoltaic (Solar Electric), IssUES \& POLICIES, http://www.seia.org/policy/solar-technology/photovoltaic-solar-electric (last visited Feb. 28, 2016).

110 Solar Energy Development Programmatic EIS, Concentrating Solar Power (CSP) Technologies, UTILITY-SCALE SOLAR ENERGY, http://solareis.anl.gov/guide/solar/csp/index.cfm (last visited Feb 28, 2016).

$111 \mathrm{Id}$.

${ }^{112} I d$.

113 Id.

114 U.S. Department of Energy, How a Wind Turbine Works, http://energy.gov/articles/how-wind-turbine-works (last updated June 20, 2014).

${ }^{115} I d$.

116 American Wind Energy Association, Wind 101: the basics of wind energy, GET THE FACTS, http://www.awea.org/Resources/Content.aspx?ItemNumber=900\&navItemNumber=587 (last visited Feb. 29, 2016).

${ }^{117} I d$. 


\section{- Endnotes Continued -}

118 U.S. DEPARTMENT OF THE INTERIOR BUREAU OF LAND MANAGEMENT, FinAL PROGRAMMATIC

ENVIRONMENTAL IMPACT STATEMENT ON WIND ENERGY DEVELOPMENT ON BLM-ADMINISTERED LANDS

IN THE WESTERN UNITED STATES 5-57 - 5-66 (2005), available at

http://windeis.anl.gov/documents/fpeis/maintext/Vol1/Vol1Complete.pdf.

119 E.F. Baerwald et al., Barotrauma is a Significant Cause of Bat Fatalities at Wind Turbines, 18 CURR. BIOL. R695 (2008) (concluding that barotrauma is responsible for a significant number of bat deaths near wind energy systems). But compare K. E. Rollins et al., A Forensic Investigation into the Etiology of Bat Mortality at a Wind Farm: Barotrauma or Traumatic Injury? 49 VET. PATHOL. ONLINE 362 (2012) (finding that only a small proportion of bat deaths can be explained by barotrauma). It should be noted that some researchers have questioned whether the pressure changes caused by wind turbines are large enough to cause fatal barotrauma. See, for example, Press Release, National Renewable Energy Laboratory, NREL Study Finds Barotrauma Not Guilty (Mar. 22, 2013), available at http://www.nrel.gov/wind/news/2013/2149.html.

${ }^{120}$ American Wind Wildlife Institute, Summary of Wind-Wildlife Interactions, https://awwi.org/resources/summary-of-wind-wildlife-interactions-2/ (last visited Feb. 29, 2016).

${ }^{121}$ U.S Department of the Interior Bureau of Land Management, supra note 118, 5-80.

122 Id. at $5-84$.

${ }^{123}$ David E. Newton, Wind Energy: A Reference Handbook 104 - 105 (2015)

${ }^{124} I d$. at $105-106$.

${ }^{125}$ Id. at 105.

${ }^{126}$ U.S. Department of the Interior Bureau of Land Management, supra note 118, at 5-37.

${ }^{127}$ Id. at 5-53.

1285 U.S.C. $\int 552$ et seq.

${ }^{129}$ U.S. Fish AND WiLDlifE SERVICE, TrACKING AND INTEGRATED LOGGING SYSTEM (TAILS) (2006), available at https://my.usgs.gov/confluence/download/attachments/409927891/TAILS brochure.pdf? version $=1 \&$ modificationDate $=1375314912318 \&$ api $={ }_{\mathrm{v}} 2$.

${ }^{130} I d$.

131 U.S. Fish and Wildlife Service, Conserving the Nature of America, http://www.fws.gov/where/ (last updated Aug. 11, 2015).

132 Malcom \& Li, supra note 14 , at 6. 


\section{- Endnotes Continued -}

133 Bureau of Land Management, Renewable Energy Projects Approved Since the Beginning of Calendar Year 2009, RENEWABLE ENERGY RESOURCES, http://www.blm.gov/wo/st/en/prog/energy/renewable energy/ Renewable Energy Projects Approved to Date.html (last visited Feb. 26, 2016).

${ }^{134} I d$.

135 Bureau of Land Management, Number of Drilling Permits Approved by Fiscal Year on FEDERAL LANDS (2014), available at http://www.blm.gov/style/medialib/blm/wo/MINERALS REALTY AND RESOURCE PROTECTION/energy/oil gas statistics/data sets.Par.65795.File.dat/numberofap dsapproved.pdf.

${ }^{136}$ For the purposes of Table 2, in categorizing projects, we used the "action/work type" recorded by FWS in TAILS. The project category listed as “Oil / Gas Exploration” includes actions recorded in TAILS as involving “Oil or Gas - Exploration / Production - Onshore," "Oil or Gas - Exploration / Production - Onshore Hydraulic Fracturing methodology," "Oil or Gas Exploration / Production," "Oil or Gas - Leasing," and "Oil or Gas." The project category listed as "Oil /Gas Pipeline” includes actions recorded in TAILS as involving "Oil or Gas Pipeline," "Oil or Gas - Pipeline - Onshore - New Construction - Below Ground," "Oil or Gas Pipeline - Onshore - New Construction - Above Ground," "Oil or Gas Pipeline - Onshore - Maintenance / Modification / Replacement / Upgrade - Below Ground," “Oil or Gas Pipeline - Onshore - Maintenance / Modification / Replacement / Upgrade - Above Ground,” and “Oil or Gas - Pipeline - Onshore Abandonment - Below Ground." The project category listed as "Wind Energy Development” includes actions recorded in TAILS as involving "Power Generation - Wind." The project category listed as "Solar Energy Development" includes actions recorded in TAILS as involving "Power Generation - Solar."

137 We understand from discussions with FWS that re-initiations are typically recorded as separate consultations in TAILS.

${ }^{138}$ It should be noted that, of the projects consulted on by FWS, 26 did not involve the drilling of oil and/or gas wells. These projects did, however, involve activities related to well drilling. For example, 4 consultations involved oil and gas lease sales proposed by BLM. 9 consultations related to projects involved the performance of geophysical and/or seismic surveys as a precursor to oil and gas drilling. 2 consultations related to projects involved the construction or alteration of roads to be used to access drilling sites. 2 consultations related to projects involving the treatment and/or disposal of water produced with from oil and gas wells. 8 consultations related to projects involving the construction of gas gathering, processing, and/or storage facilities. 1 consultation related to a gas research, development, and demonstration project.

139 At least 5 consultations, each of which is counted separately above, were undertaken with respect to a single solar energy project. Another solar energy project was the subject of at least 2 (separately counted) consultations. 


\section{- Endnotes Continued -}

140 In March 2013, FWS and BLM agreed to consolidate, into 1 review, consultation with respect to the Stateline Solar Project and Silver State South Project. Both projects involved the construction and operation of solar energy facilities in southern California. See Memorandum from Acting Field Supervisor, Ventura Fish and Wildlife Office to Field Manager, Needles Field Office, Bureau of Land Management and Assistant Field Manager, Las Vegas Field Office, Bureau of Land Management (Sep. 30, 2013) (on file with authors).

${ }^{141} I d$.

${ }^{142} I d$.

143 The table only includes species which were considered likely to be adversely affected by the project.

144 Memorandum from Western Colorado Supervisor, Fish and Wildlife Service, Ecological Services, to Field Manager, Bureau of Land Management, Grand Junction Field Office (Jul. 15, 2010) (on file with authors).

145 Memorandum from Susan K. Moore, Field Supervisor, Sacramento Fish and Wildlife Office, to Timothy Smith, U.S. Bureau of Land Management, Bakersfield Field Office (Dec. 13, 2012) (on file with authors).

${ }^{146}$ Memorandum from Western Colorado Supervisor, Fish and Wildlife Service, Ecological Services, to Field Manager, Bureau of Land Management, Grand Junction Field Office (Sep. 3, 2013) (on file with authors).

${ }^{147}$ Memorandum from Susan K. Moore, Field Supervisor, Sacramento Fish and Wildlife Office to Timothy Smith, U.S. Bureau of Land Management, Bakersfield Field Office (Dec. 13, 2012) (on file with authors).

${ }^{148} I d$.

${ }^{149}$ Memorandum from the Western Colorado Supervisor, Fish and Wildlife Service to the Field Manager, Bureau of Land Management (Jul. 15, 2010) (on file with authors) (stating that the project proponent proposed a five-year program of oil and gas exploration and development, involving the drilling of up to 107 wells on 12 existing and 67 new well pads, and associated access roads, pipelines, and handling facilities); Memorandum from the Western Colorado Supervisor, Fish and Wildlife Service to the Field Manager, Bureau of Land Management (Sep. 3, 2013) (on file with authors) (indicating that the project proponent proposed a four-year program of oil exploration, involving the drilling of up to 108 wells on 12 new well pads, and associated access roads and pipelines).

${ }^{150}$ In 1 of the consultations, undertaken by the Sacramento Field Office, the conservation measures were taken from FWS's August 17, 2010 Programmatic Oil and Gas Seismic Geophysical Survey Activities Including BLM Lands in Kern, Tulare, Kings, and Fresno Counties of California. See Memorandum from the Assistant Field Supervisor, Fish and Wildlife Service to the Field Office Manager, Bureau of Land Management (on file with authors). 


\section{- Endnotes Continued -}

151 U.S. Department of the Interior Bureau of Reclamation, Upper Colorado River Drainage Basin, UPPER COLORADO REGION, http://www.usbr.gov/uc/water/basin/tc cr.html (last updated Sep. 28, 2015).

152 Upper Colorado River Endangered Fish Recovery Program, About the Endangered Fish, GENERAL

INFORMATION, http://www.coloradoriverrecovery.org/general-information/about-fish.html (last visited Feb. 26, 2016).

153 Cooperative Agreement for Recovery Implementation Program for Endangered Species in the Upper Colorado River Basin, Between the Governors of Colorado, Utah, and Wyoming, Secretary of the Interior, and Administrator of the Western Area Power Administration (Jan. 21, 1988), available at http://www.coloradoriverrecovery.org/documents-publications/foundationaldocuments/cooperativeagreement.pdf [hereinafter RIP Cooperative Agreement].

${ }^{154}$ Extension of the Cooperative Agreement for the Recovery Implementation Program for Endangered Fish Species in the Upper Colorado River Basin, Between the Governors of Colorado, Utah, and Wyoming, Secretary of the Interior, and Administrator of the Western Area Power Administration (Dec. 6, 2001), available at http://www.coloradoriverrecovery.org/documents-publications/foundational-documents/extension.pdf; Extension of the Cooperative Agreement for the Recovery Implementation Program for Endangered Fish Species in the Upper Colorado River Basin, Between the Governors of Colorado, Utah, and Wyoming, Secretary of the Interior, and Administrator of the Western Area Power Administration (Aug. 26, 2009), available at http://www.coloradoriverrecovery.org/documents-publications/foundationaldocuments/2009extension.pdf.

155 U.S. DEPARTMENT OF THE INTERIOR FISH AND WILDLIFE SERVICE, RECOVERY IMPLEMENTATION Program FOR ENDANGERED FISH SPECIES IN THE UpPER COLORADO RIVER BASIN 4-5 - 4-6 (1987), available at http://www.coloradoriverrecovery.org/documents-publications/foundationaldocuments/1987BlueBook.pdf.

${ }^{156} I d$.

${ }^{157}$ Id. at $1-7$ and $4-6$.

${ }^{158} I d$. at 5-4 (indicating that the fee to be paid by the project proponent will be specified in the BO issued by FWS).

${ }^{159}$ FWS assesses whether sufficient progress has been made in implementing the RIP, such that it can serve as the reasonable and prudent alternative to mitigate project impacts, annually. This assessment requires an evaluation of the current status of the Endangered Colorado River Fishes relative to certain recovery goals. FWS reviews actions taken by the program participants to achieve the recovery goals and identifies additional actions that may be required.

107 | Protecting Species or Endangering Development | August 2016 


\section{- Endnotes Continued -}

${ }^{160} I d$.

${ }^{161}$ U.S. Department of the Interior Fish and Wildlife Service, supra note 155.

162 Governance Committee, Platte River ReCovery Implementation Program (2006), available at https://www.platteriverprogram.org/PubsAndData/ProgramLibrary/Platte\%20River

\%20Recovery $\% 20$ Implementation $\% 20$ Program $\% 20$ Document.pdf.

163 Platte River Recovery Implementation Program, Program Information, ABOUT THE PROGRAM, https://www.platteriverprogram.org/AboutPRRIP/Pages/ProgramInformation.aspx\#ProgramArea (last visited Mar. 1, 2016).

164 U.S. Department of the Interior, Bureau of Reclamation and U.S. Fish and Wildlife Service, Final Environmental Impact Statement: Summary S-1 (2006), available at https://www.platteriverprogram.org/PubsAndData/ProgramLibrary/TCR190\%20PRRIP\%20FEIS\%20Summary.pdf.

165 Platte River Recovery Implementation Program, Pallid Sturgeon, ABOUT THE PROGRAM, https://www.platteriverprogram.org/AboutPRRIP/Pages/PallidSturgeon.aspx (last visited Feb. 26, 2016).

166 Platte River Recovery Implementation Program, Whooping Crane, ABOUT THE Program, https://www.platteriverprogram.org/AboutPRRIP/Pages/WhoopingCrane.aspx (last visited Feb. 26, 2016).

167 Platte River Recovery Implementation Program, Interior Least Tern, ABOUT THE PROGRAM, https://www.platteriverprogram.org/AboutPRRIP/Pages/Least'Tern.aspx (last visited Feb. 26, 2016)

168 Platte River Recovery Implementation Program, Piping Plover, ABOUT THE PROGRAM, https://www.platteriverprogram.org/AboutPRRIP/Pages/PipingPlover.aspx (last visited Feb. 26, 2016).

169 Governance Committee, supra note 162, at 3.

${ }^{170} I d$ at 4.

171 The PBO defined "existing water-related activities" to include: (a) activities "that have previously undergone formal section 7 consultations and were found by the [FWS] likely to jeopardize one or more of the target species [i.e., the Platte River Fish and Bird Species] and which are dependent on the [PRRIP] to serve as the reasonable and prudent alternative for their continued operation" and (b) the "operation of existing waterrelated activities (i.e., operating as of July 1, 1997) occurring upstream of the confluence of the Loup and Platte rivers that have not undergone section 7 consultation." See U.S. Department of the Interior Fish and Wildlife Service, Biological Opinion on the Platte River Recovery Implementation Program 17-18 (2006), available at https://www.platteriverprogram.org/PubsAndData/ProgramLibrary/TCR569PRRIP\%20Biological\%200pinion.pdf. 


\section{- Endnotes Continued -}

172 The PBO uses the term "new water-related activities" to refer to new projects. In this context, the term "new water-related activities" is defined to include new surface water or hydrologically connected groundwater activities including both new projects and expansion of existing projects which may affect the quantity or timing of water reaching the associated habitats and which are implemented after July 1, 1997. Id. at 27.

${ }^{173} I d$. at 11.

${ }^{174} I d$. at 11.

175 Id. at 26.

${ }^{176} I d$. at 26.

177 Some existing water-related activities underwent consultation prior to adoption of the PRRIP. Under the PRRIP, some existing activities may be covered through compliance with the terms of the previous consultation. Other activities will be subject to revised consultations. For those activities, the PRRIP is to provide ESA compliance for the Platte River Fish and Bird Species. See Id. at 11-12, 30, 47.

178 Id. at 30 .

179 Id. at 27.

${ }^{180}$ Memorandum from the U.S. Department of the Interior Fish and Wildlife Service to the Bureau of Land Management Casper Field Office re. Three Forks Resources LLC's Government Bridge and Tipps Oil Wells Project: Platte River Depletions (Jun. 19, 2014) (on file with the authors).

18150 CFR \ 402.12(j).

182 Bureau of Land Management, Solar Energy, ENERGY, http://www.blm.gov/wo/st/en/prog/energy/solar energy.html (last visited Feb. 26, 2016).

183 Bureau of Land Management, Renewable Energy Projects Approved Since the Beginning of Calendar Year 2009, RENEWABLE ENERGY RESOURCES, http://www.blm.gov/wo/st/en/prog/energy/renewable energy/

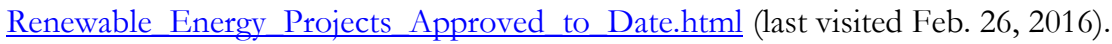

${ }^{184} I d$.

185 The table only includes species which were considered likely to be adversely affected by the project.

186 See The WiLderness Society, FACT SHEET: SOLAR ENERGY ZONES (2015) available at

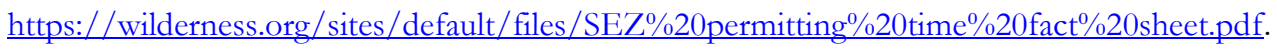

${ }^{187} \mathrm{Id}$. 


\section{- Endnotes Continued -}

${ }^{188}$ Memorandum from Field Supervisor, Carlsbad Fish and Wildlife Office, to Field Manager, El Centro District Office, Bureau of Land Management (July 26, 2011) (on file with authors); Memorandum from Assistant Field Supervisor, Palm Springs Fish and Wildlife Office, to Field Manager, El Centro District Office, Bureau of Land Management (August 15, 2012) (on file with authors).

189 Email from Biologist, Carlsbad Fish and Wildlife Office, to Wildlife Biologist, Palm Springs South Coast Field Office (June 4, 2010) (on file with authors).

${ }^{190}$ Email from Biologist, Carlsbad Fish and Wildlife Office, to El Centro Office, Bureau of Land Management (July 29, 2010) (on file with authors).

${ }^{191} I d$.

192 We understand that two of the connected action projects, occurring on private land, required BLM approval for off-site facilities. One of those projects was found to have no effect on listed species and therefore not subject to consultation, while the other underwent informal consultation, having been found to affect but not adversely affect listed species. The third connected action project required approval from the Bureau of Indian Affairs, for facilities on tribal lands, which would be used in connection with a project on BLM land (the Tule Wind project). The Tule Wind project was subject to formal consultation and is included in Table 7 above.

${ }^{193}$ The table only includes species which were considered likely to be adversely affected by the project.

${ }^{194}$ Memorandum from Field Supervisor, Carlsbad Fish and Wildlife Office, to District Manager, Bureau of Land Management, California Desert District Office (Sep. 2, 2011) (on file with authors) [hereinafter Tule Wind Project BO].

${ }^{195}$ Memorandum from Field Supervisor, Carlsbad Fish and Wildlife Office, to District Manager, California Desert District Office, Bureau of Land Management (Apr. 26, 2012) (on file with authors).

196 Operations were suspended in 2013 due to a blade failure.

${ }^{197}$ Memorandum from State Supervisor, Nevada Fish and Wildlife Office, to Assistant Field Manager, Division of Renewable Resources, Bureau of Land Management, Last Vegas Field Office (Sep. 26, 2011) (on file with authors).

198 The permits were vacated by the U.S. District Court for the District of Nevada due to deficiencies in the EIS prepared by BLM under the National Environmental Policy Act. Specifically, the Court held that BLM had not fully explained certain conclusions in the EIS and therefore remanded the document for further explanation. See Bundorft v. Jewell, 2015 U.S. Dist. LEXIS 13928 (D. Nev. Feb. 3, 2015); Bundorf v. Jewell, 2015 U.S. Dist. LEXIS 147567 (D. Nev. Oct. 30, 2015). 


\section{- Endnotes Continued -}

${ }^{199}$ Memorandum from Field Supervisor, U.S. Fish and Wildlife Service, Wyoming Field Office, to Field Manager, Bureau of Land Management, Rawlins Field Office (Sep. 5, 2012) (on file with authors).

200 Memorandum from Field Supervisor, Carlsbad Fish and Wildlife Office, to Field Manager, Palm Springs South Coast Field Office, Bureau of Land Management (Sep. 13, 2012) (on file with authors).

${ }^{201}$ Memorandum from Field Supervisor, Ventura Fish and Wildlife Office, to Supervisory Projects Manager, Renewable Energy Coordination Office, California Desert District, Bureau of Land Management (May 8, 2013) (on file with authors).

${ }^{202}$ Memorandum from Field Supervisor, U.S. Fish and Wildlife Service, Wyoming Field Office, to Field Manager, Bureau of Land Management, Rawlins Field Office (Sep. 5, 2012) (on file with authors).

${ }^{203}$ The table only includes species which were considered likely to be adversely affected by the project.

204 Memorandum from Assistant Field Supervisor, Palm Springs Fish and Wildlife Office, to District Manager, California Desert District, Bureau of Land Management (Nov. 28, 2011) (on file with authors) [hereinafter Graham Pass Wind Project BO].

205 Memorandum from Assistant Field Supervisor, Palm Springs Fish and Wildlife Office, to Field Manager, Bureau of Land Management, Palm Springs Field Office (Jun. 19, 2012) (on file with authors).

${ }^{206}$ Memorandum from Field Supervisor, Arizona Ecological Services Office, Fish and Wildlife Service, to Field Manager, Bureau of Land Management, Tucson Office (Sep. 20, 2012) (on file with authors).

${ }^{207}$ U.S. Department of the Interior Bureau of Land Management, supra note 118, at 3-1 - 3-2.

${ }^{208} I d$.

209 Id. at 3-2.

${ }^{210} I d$.

211 Id. at 5-37.

212 The Energy Policy Act of 2005 (Pub. L. 109-58, 119 Stat. 660) initially played a significant role in increasing renewable energy development on BLM land in the west. The Act's goals were to "increase production and use, advance technology development, and promote commercial development of renewable energy" in the U.S. To this end, the Act provided billions in tax incentives for renewable energy development. In 2009, the American Recovery and Reinvestment Act (Pub L. 111-5, 123 Stat. 115) provided economic benefits for renewable energy projects that began construction before the end of 2010. More recently, the Consolidated Appropriations Act of 2016 extended tax incentives for wind and solar energy.

111 | Protecting Species or Endangering Development | August 2016 


\section{- Endnotes Continued -}

213 Press Release, U.S. Department of the Interior Bureau of Land Management, Salazar Authorizes Landmark Wyoming Wind Project Site, Reaches President's Goal of Authorizing 10,000 Megawatts of Renewable Energy (Oct. 9, 2012).

214 The President's Climate Action Plan, Executive Office of the President (June 2013).

21543 U.S.C. $\int 1701(8)$.

216 U.S. DEPARTMENT OF THE INTERIOR BUREAu OF LAND MANAGEMENT, NotiCE OF COMPETITIVE LEASE SALE: OIL AND GAS (2013), available at http://www.blm.gov/style/medialib/blm/ut/lands and minerals/oil and gas/november 2013.Par.69056.File.dat/NoticeOfSale.pdf

217 U.S. Department of the Interior Bureau of Land Management, Environmental Assessment DOI-BLM-UTG021-2013-0021-EA: November 2013 Oil and Gas Lease Sale 18-19 (2013), available at https://www.blm.gov/ut/enbb/files/PFO.2013.Lease.Sale.FinalEA.8.16.13.pdf; U.S. Department of the Interior Bureau of Land Management, Environmental Assessment DOI-BLM-UT-F010-2013-133-EA:

November 2013 Oil and Gas Lease Sale 19-20 (2013), available at https://www.blm.gov/ut/enbb/files/Nov 2013 Vernal Lease Sale EA 08162013.pdf

${ }^{218}$ Memorandum from Utah Field Supervisor, Ecological Services, U.S. Fish and Wildlife Service to Bureau of Land Management (Dec. 2, 2013) (on file with authors).

${ }^{219} I d$.

${ }^{220}$ See, for example, Memorandum from Utah Field Supervisor, U.S. Fish and Wildlife Service to Field Office Manager, Bureau of Land Management, Vernal Field Office (Oct. 23, 2008) (on file with authors) [hereinafter 2008 Memorandum from FWS Utah Office to BLM Utah Office]. See also Memorandum from Utah Field Supervisor, U.S. Fish and Wildlife Service to Director, Bureau of Land Management, Utah State Office (Jun. 19, 2007) (on file with authors); Memorandum from Utah Field Supervisor, Biological Services, U.S. Fish and Wildlife Service to State Director, Bureau of Land Management, Utah State Office (Dec. 16, 2004) (on file with authors) [hereinafter 2004 Memorandum from FWS Utah Office to BLM Utah Office].

2212008 Memorandum from FWS Utah Office to BLM Utah Office, supra note 131.

2222004 Memorandum from FWS Utah Office to BLM Utah Office, supra note 131.

2232008 Memorandum from FWS Utah Office to BLM Utah Office, supra note 131. See also 2004

Memorandum from FWS Utah Office to BLM Utah Office, supra note 131.

2242004 Memorandum from FWS Utah Office to BLM Utah Office, supra note 131.

225 Memorandum from Utah Field Supervisor, Ecological Services, U.S. Fish and Wildlife Service to Bureau of Land Management (Dec. 2, 2013) (on file with authors).

112 | Protecting Species or Endangering Development | August 2016 


\section{- Endnotes Continued -}

2262004 Memorandum from FWS Utah Office to BLM Utah Office, supra note 131.

${ }^{227}$ U.S. Fish and Wildlife Service, Blunt-Nosed Leopard lizard (Gambelia silus), ECOS ENVIRONMENTAL CONSERVATION ONLINE SYSTEM, http://ecos.fws.gov/ecp0/profile/speciesProfile?spcode=C001 (last visited Jul. 13, 2016).

228 U.S. FiSH AND WiLDlifE SERVICE, SPECIES ACCOUNT: GiANT KANGAROO RAT (2010), available at http://www.fws.gov/sacramento/es species/Accounts/Mammals/Documents/giant kangaroo rat.pdf.

${ }^{229}$ U.S. Fish AND WiLdLIFE SERVICE, SpECIES ACCOUnT: TiPTON KANGAROO RAT (2010), available at http://www.fws.gov/sacramento/es species/Accounts/Mammals/Documents/tipton kangaroo rat.pdf

230 U.S. Fish and Wildlife Service, San Joaquin Kit fox (V ulpes macrotis mutica), ECOS ENVIRONMENTAL CONSERVATION ONLINE SYSTEM, http://ecos.fws.gov/tess public/profile/speciesProfile.action?spcode=A006 (last visited Feb. 26, 2015).

${ }^{231}$ California Department of Fish and Wildlife, Bakersfield Cactus, CALIFORNIA THREATENED AND ENDANGERED PLANT PROFILES, https://www.wildlife.ca.gov/Conservation/Plants/Endangered/Opuntiabasilaris-var-treleasei (last visited Feb. 26, 2015)

232 Center for Plant Conservation, Caulanthus californicus, PLANT PROFILE, http://www.centerforplant conservation.org/collection/cpc viewprofile.asp?CPCNum=842 (last updated Mar. 4, 2010).

233 California State University Stanislaus, Kern mallow, ENDANGERED SPECIES RECOVERY PROGRAM, http://esrp.csustan.edu/speciesprofiles/profile.php?sp=erke (last visited Feb. 26, 2015).

234 U.S. Fish AND WiLdlifE SERVICE, SPECIES ACCOUNT: SAN JOAQUIN WOOLY-ThreADS (2010), available at https://www.fws.gov/sacramento/es species/Accounts/Plants/Documents/San Joaquin woolythreads.pdf. 235 Memorandum from Field Supervisor, Ecological Services, Sacramento Field Office, U.S. Fish and Wildlife Service to Caliente Resource Area Manager, Bureau of Land Management (Jul. 17, 1996) (on file with author).

236 Memorandum from Assistant Field Supervisor, Sacramento Fish and Wildlife Office to Manager, Bureau of Land Management (Sep. 28, 2001) (on file with authors).

${ }^{237} I d$. at 2 .

${ }^{238} \mathrm{Id}$.

${ }^{239} I d$.

${ }^{240} I d$.

${ }^{241} I d$. at 1. 


\section{- Endnotes Continued -}

242 Surveys are not required where a project is conducted in high density oil fields. See $I d$. at 38 .

243 "Previously undisturbed habitat" is defined to include habitat which has previously been disturbed but subsequently restored to its natural state. See $I d$. at 20 .

${ }^{244}$ For Kern mallow habitat in Kings County, the compensation ratio will be 9:1 for permanent impacts and 6:1 for temporary impacts, except in high-density oil fields, where the compensation ration for Kern mallow habitat will be 6:1 for all impacts. See $I d$. at 20, 34 .

245 "Temporary impact" is defined to mean "a short term even whose effects are relaxed almost immediately or within a short period (2 years) after the event." See Id. at 20.

246 Fram Operating, LLC, The Proposed Whitewater Unit Master Development Plan 1 (2011), available at http://www.westernlaw.org/sites/default/files/Fram Whitewater Unit Revised MDP 8-1711\%5B1\%5D.pdf.

${ }^{247} I d$.

${ }^{248} I d$.

${ }^{249} I d$. at 2.

${ }^{250}$ U.S. DEPARTMENT OF THE INTERIOR BUREAU OF LAND MANAGEMENT, DECISION RECORD: DOI-BLMCO-130-2012-0003-EA 1 (2014), available at http://www.blm.gov/co/st/en/fo/gjfo/energy/proposed whitewater.html.

${ }^{251} I d$.

${ }^{252} I d$.

253 Memorandum from Western Colorado Supervisor, Fish and Wildlife Service, Ecological Services, to Field Manager, Bureau of Land Management, Grand Junction Field Office (Sep. 3, 2013) (on file with authors) [hereinafter Whitewater Unit Master Development Plan BO].

${ }^{254}$ U.S. Department of the Interior Bureau of Land Management, Environmental Assessment for the Fram Whitewater Unit Master Development Plan 31 (2014), available at http://www.blm.gov/co/st/en/fo/gjfo/energy/proposed whitewater.html.

${ }^{255}$ Id. at 131.

256 U.S. Fish and Wildlife Service, Colorado Hookless Cactus, ENDANGERED SPECIES, http://www.fws.gov/mountain-prairie/species/plants/ColoradoHooklessCactus/index.html (last updated May $10,2010)$. 


\section{- Endnotes Continued -}

${ }^{257}$ U.S. Department of the Interior Bureau of Land Management, Environmental Assessment for the Fram Whitewater Unit Master Development Plan 131 (2014), available at

http://www.blm.gov/co/st/en/fo/gjfo/energy/proposed_whitewater.html.

${ }^{258} I d$.

${ }^{259}$ Memorandum from Western Colorado Supervisor, Fish and Wildlife Service, Ecological Services, to Field Manager, Bureau of Land Management, Grand Junction Field Office (Sep. 3, 2013) (on file with authors) [hereinafter Whitewater Unit Master Development Plan BO].

${ }^{260} \mathrm{Id}$.

${ }^{261} I d$. at 1.

${ }^{262} I d$.

${ }^{263} I d$. at 3.

${ }^{264} I d$. at 1.

${ }^{265}$ Memorandum from Western Colorado Supervisor, Fish and Wildlife Service, Ecological Services, Field Manager, Bureau of Land Management, Grand Junction Field Office (Jul. 15, 2010) (on file with authors) [hereinafter WPMDP BO].

$266 I d$. at 3.

${ }^{267} I d$. at 1.

268 Id. at 3.

${ }^{269} I d$. at 3.

${ }^{270} I d$. at 11.

${ }^{271} I d$. at 12.

${ }^{272} I d$. at 2 .

${ }^{273}$ U.S. Fish and Wildlife Service, Debeque phacelia (Phacelia submutica), ECOS ENVIRONMENTAL CONSERVATION ONLINE SYSTEM, https://ecos.fws.gov/tess public/profile/speciesProfile. action?spcode=Q1G6 (last visited Mar. 1, 2016).

274 This includes all pre-consultation discussions between BLM and FWS.

275 WPMDP BO, supra note 265, at 2.

${ }^{276} I d$. at 15. 


\section{- Endnotes Continued -}

277 Id.

${ }^{278} I d$. at $13-14$.

${ }^{279} I d$. at 14.

${ }^{280} I d$. at 6.

${ }^{281} I d$.

282 See Memorandum from Western Colorado Supervisor, Fish and Wildlife Service, Ecological Services, to Field Manager, Bureau of Land Management, Grand Junction Field Office (Jun. 22, 2011) (on file with authors).

${ }^{283} I d$. at 1.

${ }^{284} I d$.

${ }^{285} I d$.

${ }^{286}$ Memorandum from Field Supervisor, U.S. Fish and Wildlife Service, Wyoming Field Office to Field Manager, Bureau of Land Management, Rock Springs Field Office (Jul. 21, 2011) (on file with authors).

${ }^{287} I d$.

${ }^{288} I d$.

${ }^{289} \mathrm{Id}$.

${ }^{290} I d$.

${ }^{291} I d$.

${ }^{292} I d$.

${ }^{293}$ While FWS may on occasion request additional information about a project under review, no such request was made in this case, with FWS relying solely on the material in BLM's initial letter.

${ }^{294}$ Memorandum from Utah Field Supervisor, Ecological Services, U.S. Fish and Wildlife Service to Field Office Manager, Vernal Field Office, Bureau of Land Management (Nov. 21, 2011) (on file with author).

${ }^{295} I d$. at 5.

${ }^{296} I d$.

${ }^{297}$ Energy Policy Act of 2005, \365; 42 U.S.C. $\$ 15924$ (2016). 


\section{- Endnotes Continued -}

298 Memorandum of Understanding on Implementation of Section 365 of the Energy Policy Act of 2005 Pilot Project to Improve Federal Permit Coordination, Between U.S. Department of the Interior, U.S. Department of Agriculture, U.S. Environmental Protection Agency, and U.S. Army Corps of Engineers (Oct. 24, 2005), available at http://www.fws.gov/habitatconservation/Energy Act \%202005 Pilot Project \%20MOU Final Signed.pdf.

${ }^{299} I d$.

300 Memorandum from Utah Field Supervisor, Ecological Services, U.S. Fish and Wildlife Service to Field Office Manager, Vernal Field Office, Bureau of Land Management (Nov. 21, 2011) (on file with authors).

${ }^{301} I d$. at 7.

${ }^{302} I d$. at 6.

303 Memorandum from Field Supervisor, U.S. Fish and Wildlife Service, Wyoming Field Office, to Field Manager, Bureau of Land Management, Casper Field Office (Jun. 19, 2014) (on file with authors).

${ }^{304} I d$. at 1 .

${ }^{305} I d$. at 3.

$306 I d$. at 1.

${ }^{307} I d$. at 1.

308 Id. at 3.

309 U.S. DEPARTMENT OF THE INTERIOR FISH AND WILDLIFE SERVICE, BIOLOGICAL OPINION FOR THE Stateline Solar AND Silver State SOlar SOUth ProjeCtS 2 (2013), available at http://www.blm.gov/style/medialib/blm/nv/field offices/las vegas field office/energy/silver state south/ biological opinion.Par.89501.File.dat/BO FINAL.pdf.

310 U.S. DEPARTMENT OF THE INTERIOR Fish AND WILDLIFE SERVICE, FINAL- PROJECT-LEVEL FORMAL CONSUltations For Four SOlar ENERgy Projects in the Dry LAKE SOlar ENERgy Zone, Clark COUNTY, NEVADA (2015), available at https://www.blm.gov/epl-frontoffice/projects/nepa/42098/58937/64083/Appendix_C_Biological_Opinion.pdf.

311 Tule Wind Project BO, supra note 194.

${ }^{312} I d$. at $2-3$.

${ }^{313} I d$. at 1 . Tule Wind, LLC also sought approval from the US. Army Corps of Engineers under the Clean Water Act to discharge fill material within waters of the U.S.

${ }^{314} I d$. at 14. 


\section{- Endnotes Continued -}

$315 I d$.

${ }^{316} I d$. at $3-6$.

317 Graham Pass Wind Project BO, supra note 204.

${ }^{318} I d$. at 1.

${ }^{319} I d$.

${ }^{320} I d$. at 6 ,

${ }^{321} I d$. at $2-4$.

${ }^{322} I d$. at $5-6$.

${ }^{323} I d$. at 6 .

${ }^{324}$ Id. at 7.

${ }^{325} I d$.

${ }^{326} I d$. at 8 . 